Franz Mauthner | Werner Weiss

\title{
SOLAR HEAT WORLDWIDE
}

\section{Markets and Contribution to the Energy Supply 2012}

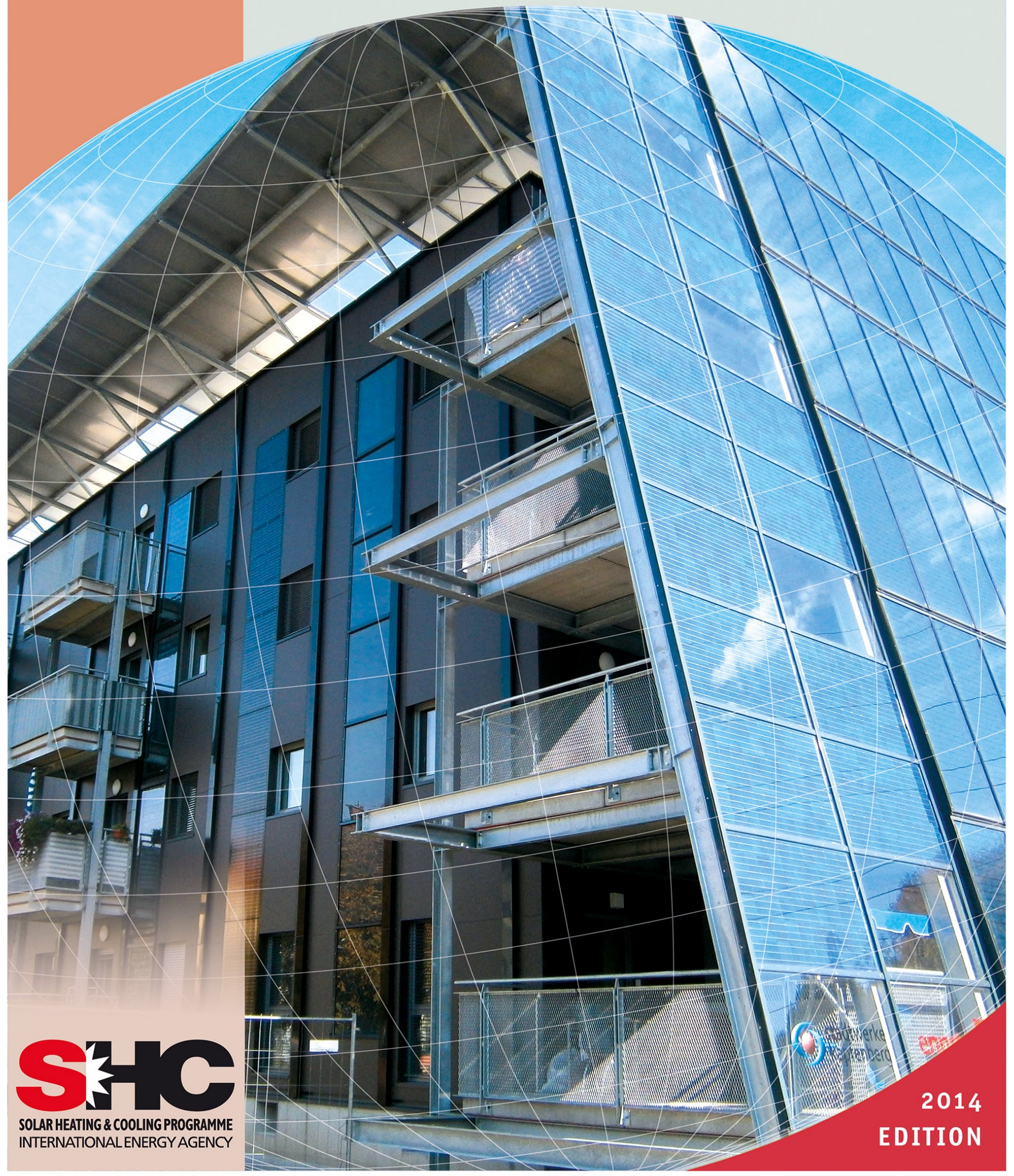





\section{SOLAR HEAT WORLDWIDE}

Markets and Contribution to the Energy Supply 2012

EDITION 2014

Franz Mauthner and Werner Weiss

AEE INTEC

AEE - Institute for Sustainable Technologies

A-8200 Gleisdorf, Austria

IEA Solar Heating \& Cooling Programme, June 2014

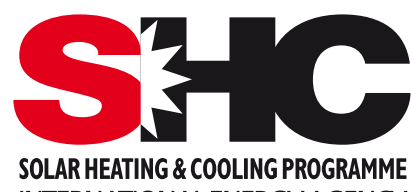

INTERNATIONALENERGY AGENCY

Supported by the Austrian Ministry for Transport, Innovation and Technology

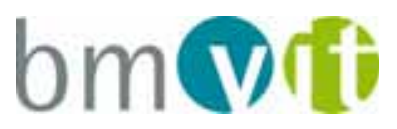

Cover: AEE INTEC / Advanced building renovation of a residential building to a plus-energy building with prefabricated solar-active roof and façade elements

Design, Grafics, Typesetting \& Imageprocessing: STEINHUBER INFODESIGN, Graz, Austria 


\section{Table of Contents}

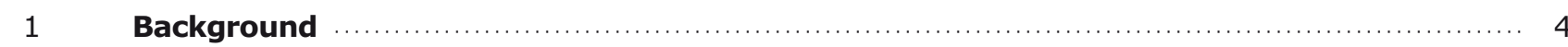

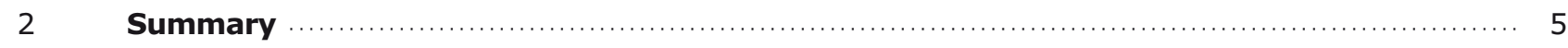

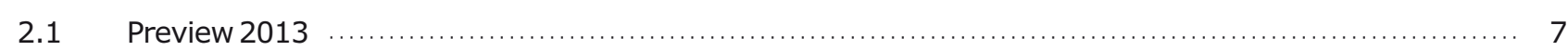

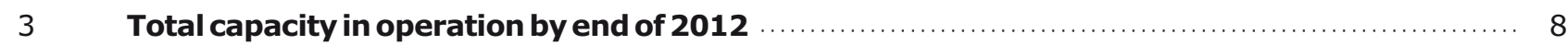

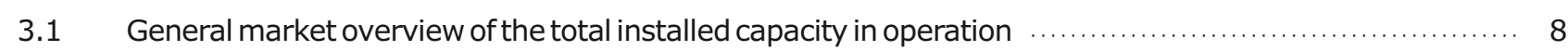

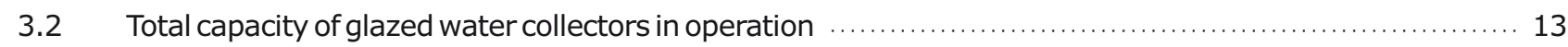

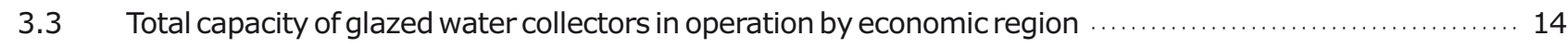

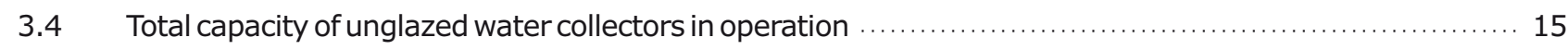

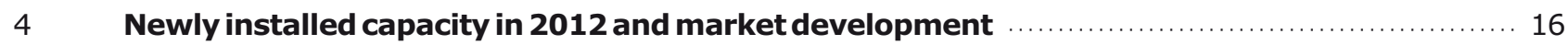

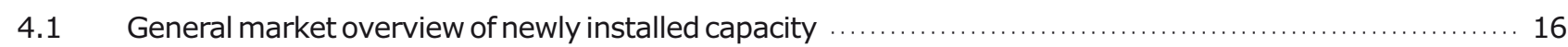

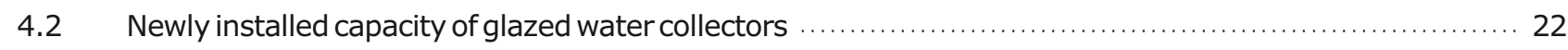

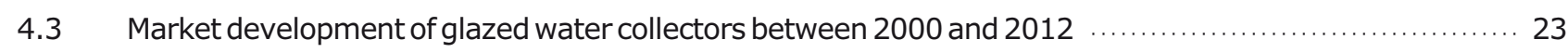

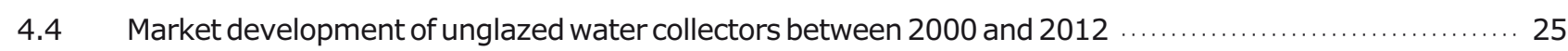

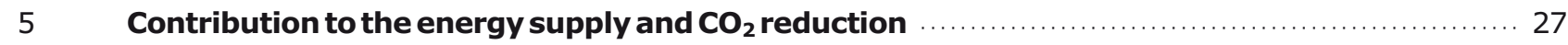

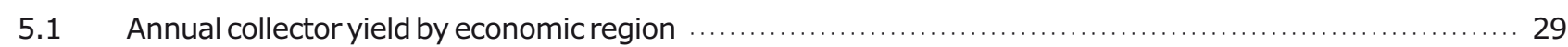

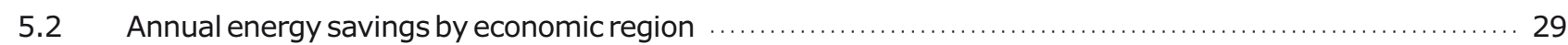

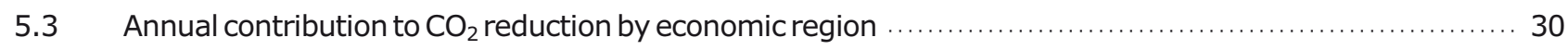

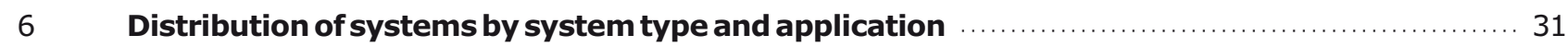

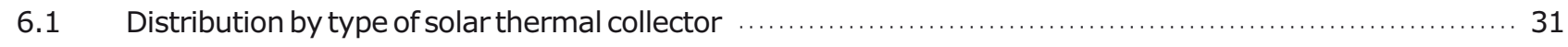

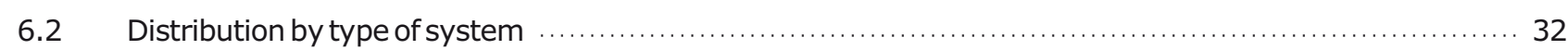

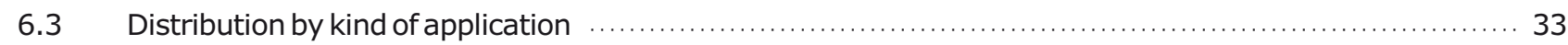

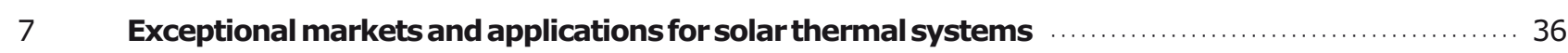

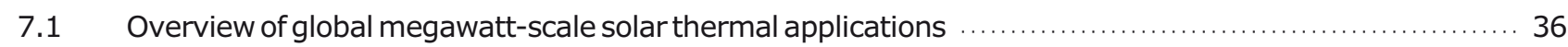

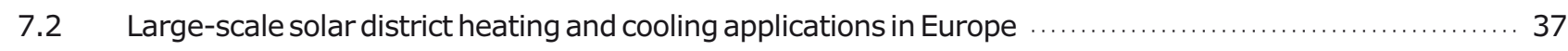

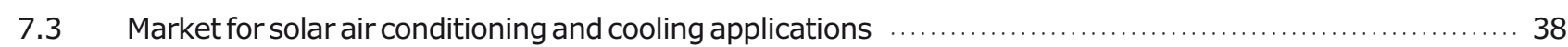

7.4 Good practice examples of world-wide installed solar process heat applications …........................ 39

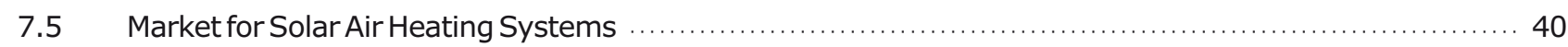

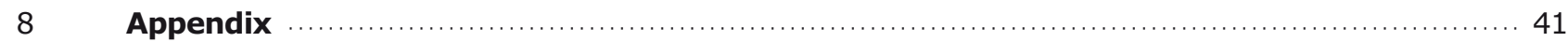

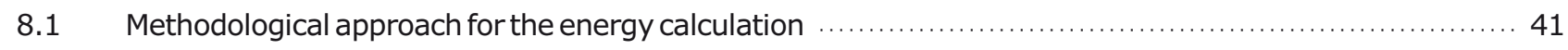

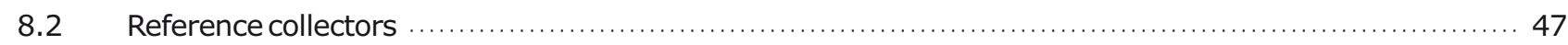

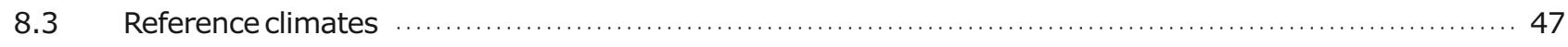

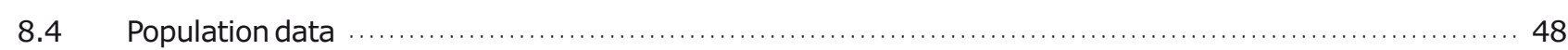

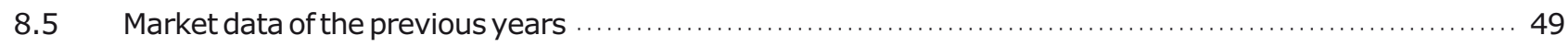

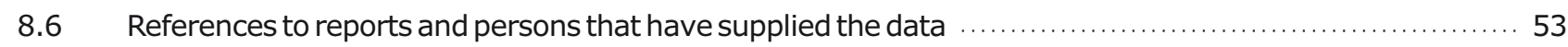

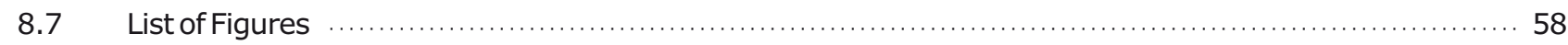

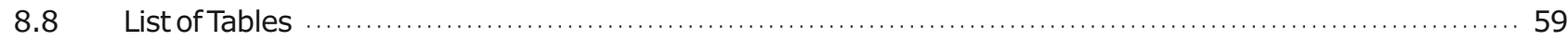




\section{$1 \quad$ Background}

This report was prepared within the framework of the Solar Heating and Cooling Programme (SHC) of the International Energy Agency (IEA). The goal of the report is to document the solar thermal capacity installed in the important markets worldwide, and to ascertain the contribution of solar thermal systems to the supply of energy and the $\mathrm{CO}_{2}$ emissions avoided as a result of operating these systems. The collectors documented are unglazed collectors, glazed flat-plate collectors (FPC) and evacuated tube collectors (ETC) with water as the energy carrier as well as glazed and unglazed air collectors.

The data were collected from a survey of the national delegates of the SHC Programme's Executive Committee and other national experts active in the field of solar thermal energy. As some of the 58 countries included in this report have very detailed statistics and others have only estimates from experts, the data was checked for its plausibility on the basis of various publications.

Starting with the collector area, respectively the capacity installed, the contributions of solar thermal systems towards the supply of energy and the reduction of $\mathrm{CO}_{2}$ were ascertained.

The 58 countries included in this report represent 4.4 billion people, or about $63 \%$ of the world's population. The installed capacity in these countries is estimated to represent $95 \%$ of the solar thermal market worldwide.

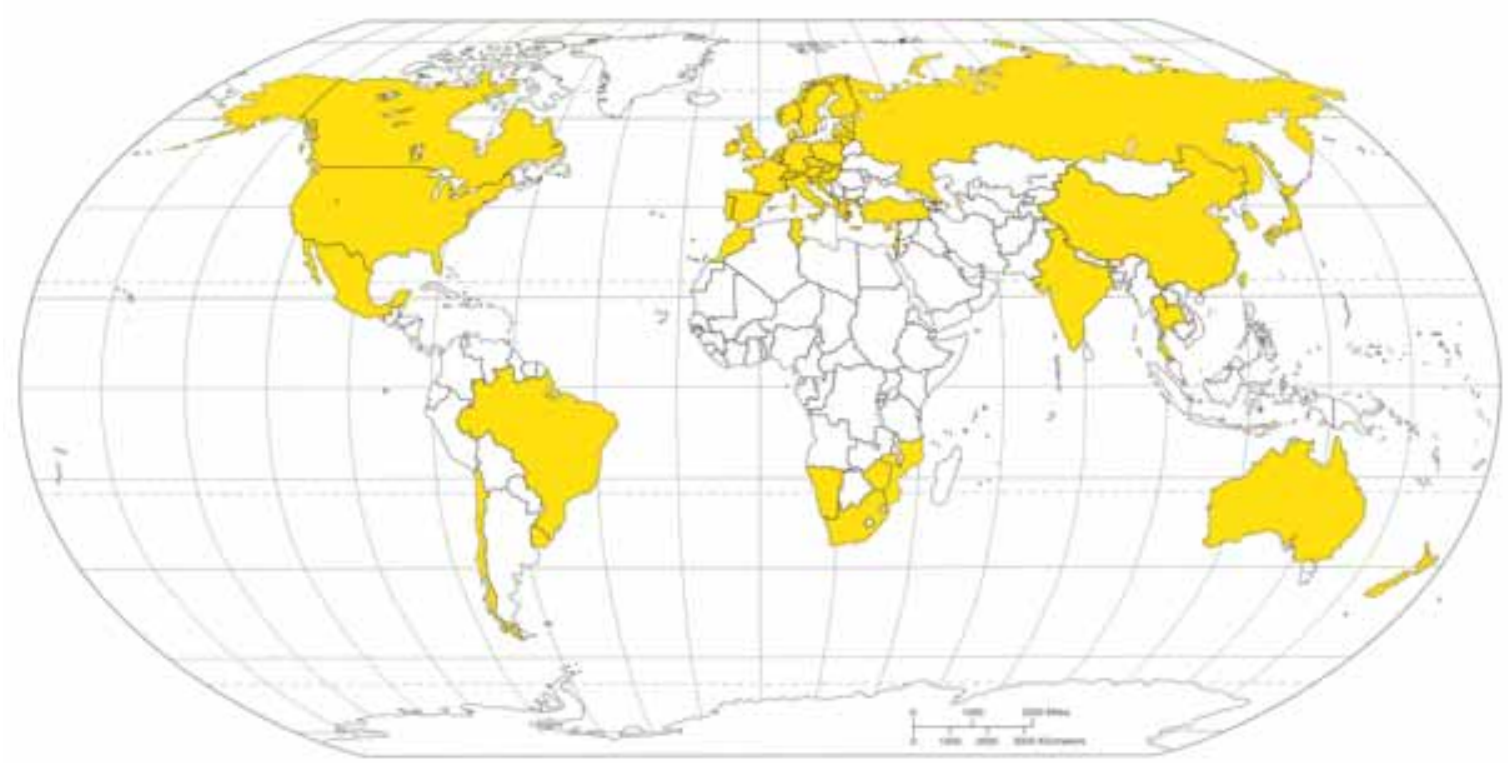

Figure 1: Countries represented in this report 


\section{Summary}

This report comprises solar thermal market data from 58 countries covering an estimated $95 \%$ of the worldwide market.

\section{Total installed capacity in operation worldwide by the end of 2012}

By the end of 2012, an installed capacity of $269.3 \mathrm{GW}_{\mathrm{th}}$, corresponding to a total of 384.7 million square meters ${ }^{1}$ of collector area was in operation in the 58 countries recorded in this report.

The vast majority of the total capacity in operation was installed in China (180.4 $\mathrm{GW}_{\mathrm{th}}$ ) and Europe (42.8 $\mathrm{GW}_{\mathrm{th}}$ ), which together account for $83 \%$ of the total installed. The remaining installed capacity was shared between the United States and Canada (17.2 GW th), Asia excluding China (10.3 GW th), Latin America (7.4 GW th), Australia and New Zealand (5.4 GW $\mathrm{GW}_{\text {th }}$ ), the MENA ${ }^{2}$ countries Israel, Jordan, Lebanon, Morocco and Tunisia (4.9 GW th $)$ and the Sub-Sahara African countries Mozambique, Namibia, South Africa and Zimbabwe (1.0 GW th).

The breakdown of the cumulated capacity in operation in 2012 by collector type is $26.4 \%$ glazed flat-plate collectors, $64.6 \%$ evacuated tube collectors, $8.4 \%$ unglazed water collectors, and $0.6 \%$ glazed and unglazed air collectors.

The leading countries in cumulated unglazed and glazed water collector capacity in operation in 2012 per 1,000 inhabitants were Cyprus (548 kW th/1,000 inhabitants), Austria (420 kW th/1,000 inhabitants), Israel (385 kW th/1,000 inhabitants), Barbados (320 kW th/1,000 inhabitants), Greece (268 kW th/1,000 inhabitants), Australia (233 kWth/ 1,000 inhabitants), Germany (145 kW $\mathrm{th} / 1,000$ inhabitants), Turkey (136 kW th/ 1,000 inhabitants), China (134 kW th/ 1,000 inhabitants) and Jordan (121 kWth/1,000 inhabitants).

\section{Newly installed capacity worldwide in 2012}

In the year 2012, a capacity of $52.7 \mathrm{GW}_{\text {th }}$, corresponding to 75.3 million square meters of solar collectors, was installed worldwide. This means an increase in new collector installations of 9.4\% compared to the year 2011.

The main markets were in China (44.7 $\mathrm{GW}_{\mathrm{th}}$ ) and Europe $\left(3.7 \mathrm{GW}_{\mathrm{th}}\right.$ ), which together accounted for $92 \%$ of the new collector installations in 2012. The rest of the market was shared between Asia excluding China (1.3 GW $\left.\mathrm{Gh}_{\mathrm{th}}\right)$, Latin America represented by Brazil, Chile and Mexico $\left(1.0 \mathrm{GW}_{\mathrm{th}}\right)$, the United States and Canada $\left(0.8 \mathrm{GW}_{\text {th }}\right)$, Australia $\left(0.7 \mathrm{GW}_{\text {th }}\right)$, the MENA region represented by Israel, Jordan, Lebanon, Morocco and Tunisia $\left(0.4 \mathrm{GW}_{\mathrm{th}}\right)$ and the SubSahara African countries Mozambique, South Africa and Zimbabwe (0.1 GW $\left.\mathrm{GW}_{\text {th }}\right)$.

The breakdown of the newly installed capacity in 2012 by collector type is $15.9 \%$ glazed flat-plate collectors, $81.0 \%$ evacuated tube collectors, 3.0\% unglazed water collectors and $0.2 \%$ glazed and unglazed air collectors.

To compare the installed capacity of solar thermal collectors with other energy sources, solar thermal experts agreed upon a methodology to convert installed collector area into solar thermal capacity at a joint meeting of the IEA SHC Programme and major solar thermal trade associations held September 2004 in Gleisdorf, Austria. The represented associations from Austria, Canada, Germany, the Netherlands, Sweden and United States as well as the European Solar Thermal Industry Federation (ESTIF) and the IEA SHC Programme agreed to use a factor of $0.7 \mathrm{~kW}$ th $/ \mathrm{m}^{2}$ to derive the nominal capacity from the area of installed collectors. 
The leading countries in newly install unglazed and glazed water collector capacity in 2012 per 1,000 inhabitants were China (33 kW $\mathrm{kth}_{\mathrm{th}} / 1,000$ inhabitants); Australia (29 kWth $/ 1,000$ inhabitants); Israel ( $29 \mathrm{~kW}_{\mathrm{th}} / 1,000$ inhabitants), Austria (18 kW $\mathrm{kth}_{\mathrm{th}} / 1,000$ inhabitants); Greece (16 kWth $/ 1,000$ inhabitants); Denmark (14 kWth $/ 1,000$ inhabitants); Turkey (14 kW $\mathrm{kth}_{\mathrm{th}} / 1,000$ inhabitants); Switzerland (14 kWth $/ 1,000$ inhabitants); Cyprus (14 kW $\mathrm{kW}_{\mathrm{th}} / 1,000$ inhabitants) and Lebanon (10 $\mathrm{kW}_{\mathrm{th}} / 1,000$ inhabitants).

\section{Contribution to the energy supply and $\mathrm{CO}_{2}$ reduction}

The annual collector yield of all water-based solar thermal systems in operation by the end of 2012 was $227.8 \mathrm{TWh}$ $(=820 \mathrm{PJ})$ in the 58 recorded countries. This corresponds to an energy savings equivalent to 24.5 million tons of oil and 79.1 million tons of $\mathrm{CO}_{2}$.

\section{Distribution of systems by system type and application}

The thermal use of the sun's energy varies greatly from region to region across the globe. It can be roughly distinguished by the type of solar thermal collector used (unglazed water collectors, evacuated tube collectors, flat plate collectors, glazed and unglazed air collectors, concentrating collectors), the type of system operation (pumped solar thermal systems, thermosiphon systems), and the main type of application (swimming pool heating, domestic hot water preparation, space heating, heating of industrial processes, solar district heating or solar thermal cooling).

For unglazed and glazed water collectors, the evacuated tube collector dominated with a $65 \%$ share of the cumulated capacity in operation and a $82 \%$ share of the newly installed capacity. In China, vacuum tube collectors played an important role, and since this was by far the largest market, the worldwide figures tend towards a higher share of this type of solar thermal collector.

Unglazed water collectors accounted for $8 \%$ of the cumulated water collectors installed worldwide and the share tended to decrease. In 2012 the share of unglazed water collectors was 3\% of the newly installed capacity.

Worldwide, around $75 \%$ of all solar thermal systems installed are thermosiphon systems and $25 \%$ are pumped solar heating systems. Similar to the distribution by type of solar thermal collector in total numbers, the Chinese market influenced the overall figures most, and in 2012 89\% of the newly installed systems were estimated to be thermosiphon systems while pumped systems only accounted for $11 \%$.

In general, thermosiphon systems are more common in warm climates such as in Africa, South and East Asia (excluding China), Latin America, southern Europe and the MENA region. In these regions thermosiphon systems are more often equipped with flat plate collectors, while in China the typical thermosiphon system for domestic hot water preparation is equipped with evacuated tubes.

The calculated number of water-based solar thermal systems in operation was approximately 78 million by the end of 2012. The breakdown is $8 \%$ used for swimming pool heating, $78 \%$ used for domestic hot water preparation in single family houses, and $9 \%$ attached to larger domestic hot water consumers, such as multifamily houses, hotels, hospitals, schools, etc. Around $4 \%$ of the worldwide installed capacity supplied heat for both domestic hot water and space heating (solar combi-systems). The remaining systems accounted for about $1 \%$ or almost 4 million square meters of solar thermal collectors and delivered heat to district heating networks, industrial processes or thermally driven solar cooling applications.

Compared to the cumulated installed capacity, the share of swimming pool heating was much less for new installations ( $8 \%$ of total capacity and only $2 \%$ of newly installed capacity). To a lesser extent, this is also true for domestic 
hot water systems in single-family houses. Here the share shows a declining trend, but with a share of $77 \%$ in 2012 this is still the most common application for solar thermal systems worldwide. The shares of large-scale domestic hot water applications tended to increase ( $9 \%$ of total capacity and already $17 \%$ of newly installed capacity) while the share of solar-combi systems remained at a low level of 3-4\%.

The calculated number of different types of solar thermal systems in operation was approximately 78 million.

\subsection{Preview 2013}

The estimated total capacity of solar thermal collectors in operation worldwide by the end of 2013 is $330 \mathrm{GW}_{\text {th }}$, or 471 million square meters of collector area. This corresponds to an annual collector yield of 281 TWh, which is equivalent to savings of 30.1 million tons of oil and 97.4 million tons of $\mathrm{CO}_{2}{ }^{3}$.

The preview for 2013 is based on latest market data from Austria, Brazil, China, Germany, India, Japan, Mexico, Portugal and Spain, which represent more than $90 \%$ of the global solar thermal market. The other countries were estimated according to their trend over the past two years.

Compared with other forms of renewable energy, solar heating's contribution in meeting global energy demand is, besides the traditional renewable energies like biomass and hydropower, second only to wind power (Figure 2). And in installed capacity, solar thermal is the leader.

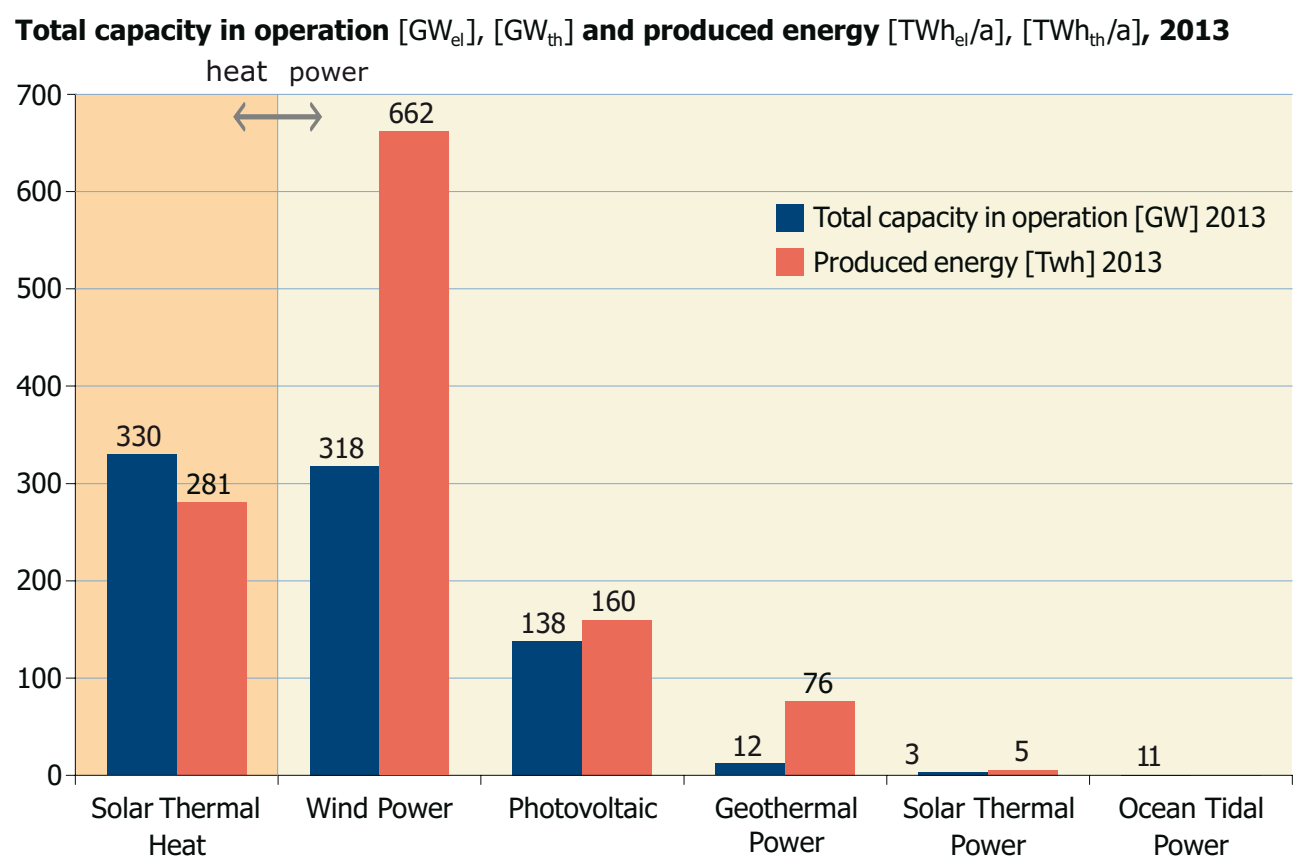

Figure 2: Total capacity in operation [GW $\mathrm{el}],\left[\mathrm{GW}_{\mathrm{th}}\right] 2013$ and annual energy generated [TWh $\mathrm{TW}_{\mathrm{el}},\left[\mathrm{TWh}_{\mathrm{th}}\right]$

(Sources: AEE INTEC, GWEC, EPIA, IEA PVPS, Navigant Research, Ocean Energy Systems, REN21, U.S. Geothermal Energy Association)

\section{Employment}

Based on data collected from the detailed country reports, the number of jobs in the fields of production, installation and maintenance of solar thermal systems is estimated to be 460,000 worldwide in 2013. 


\section{Total capacity in operation by end of 2012}

This report aims to give the actual collector area in operation and not the cumulated collector area that has ever been installed in a country. To determine the collector area (and respective capacity) in operation, either official country reports on the lifetime were used or, if such reports were not available, a 25-year lifetime for a system was calculated. The collector area in operation was then calculated using a linear equation. For China, the methodology of the Chinese Solar Thermal Industry Federation (CSTIF) was used. According to the CSTIF approach the operation lifetime is considered to be less than 10 years.

The analysis further aims to distinguish between different types of solar thermal collectors, such as unglazed water collectors, glazed water collectors including flat plate collectors (FPC) and evacuated tube collectors (ETC) as well as unglazed and glazed air collectors.

\subsection{General market overview of the total installed capacity in operation}

By the end of 2012, an installed capacity of $269.3 \mathrm{GW}_{\text {th }}$ corresponding to a total of 384.7 million square meters of collector area was in operation in the 58 countries recorded in this report. These 58 countries represent 4.4 billion people, which is $63 \%$ of the world's population. The installed capacity in these countries represents more than $95 \%$ of the solar thermal market worldwide.

The vast majority of the total capacity in operation was installed in China (180.4 GW $\mathrm{Gh}_{\text {th }}$ ) and Europe (42.8 $\left.\mathrm{GW}_{\text {th }}\right)$, which together accounted for $83 \%$ of the total installed. The remaining installed capacity was shared between the United States and Canada (17.2 $\mathrm{GW}_{\text {th }}$ ), Asia excluding China (10.3 $\mathrm{GW}_{\text {th }}$ ), Latin America (7.4 $\left.\mathrm{GW}_{\text {th }}\right)$, Australia and New Zealand (5.4 GW $\mathrm{Gh}_{\text {th }}$ ), the MENA countries Israel, Jordan, Lebanon, Morocco and Tunisia (4.9 $\mathrm{GW}_{\text {th }}$ ) and Sub-Sahara African countries Mozambique, Namibia, South Africa and Zimbabwe $\left(1.0 \mathrm{GW}_{\mathrm{th}}\right)$.

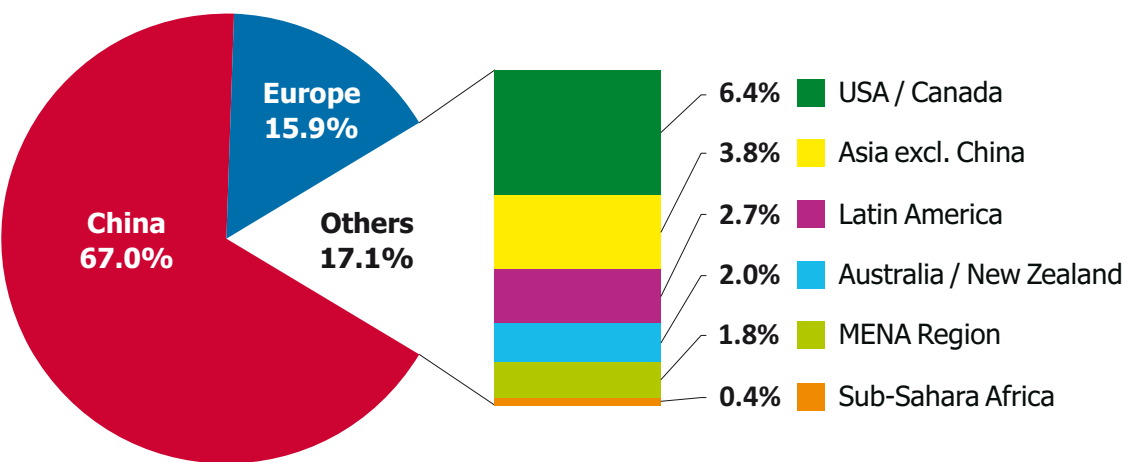

Sub-Sahara Africa: Asia excluding China: Latin America:

Europe: MENA Region:
Mozambique, Namibia, South Africa, Zimbabwe India, Japan, Korea South, Taiwan, Thailand Brazil, Chile, Mexico, Uruguay EU 28, Albania, Macedonia, Norway, Switzerland, Russia, Turkey Israel, Jordan, Lebanon, Morocco, Tunisia

Figure 3: Share of the total installed capacity in operation (glazed and unglazed water and air collectors) by economic region at the end of 2012 


\begin{tabular}{|c|c|c|c|c|c|c|}
\hline \multirow{2}{*}{ Country } & \multicolumn{3}{|c|}{ Water Collectors } & \multicolumn{2}{|c|}{ Air Collectors } & \multirow{2}{*}{ TOTAL $\left[\mathrm{MW}_{\mathrm{th}}\right]$} \\
\hline & unglazed & FPC & ETC & unglazed & glazed & \\
\hline Albania & & 77.8 & 0.6 & & & 78.3 \\
\hline Australia & $3,045.0$ & $2,035.6$ & 47.6 & 196.0 & 5.0 & $5,329.2$ \\
\hline Austria & 391.0 & $3,002.7$ & 55.7 & & 1.3 & $3,450.8$ \\
\hline Barbados* & & 92.2 & & & & 92.2 \\
\hline Belgium & 31.5 & 230.6 & 38.5 & & & 300.7 \\
\hline Brazil & $1,620.3$ & $4,163.1$ & & & & $5,783.4$ \\
\hline Bulgaria & & 84.0 & 1.4 & & & 85.5 \\
\hline Canada & 544.7 & 43.0 & 25.0 & 244.8 & 16.9 & 874.4 \\
\hline Chile*** & & 56.0 & & & & 56.0 \\
\hline China & & $12,177.7$ & $168,212.3$ & & & $180,390.0$ \\
\hline Croatia\# & & 84.0 & & & & 84.0 \\
\hline Cyprus & 1.5 & 605.7 & 16.2 & & & 623.4 \\
\hline Czech Republic & 327.6 & 235.1 & 61.5 & & & 624.2 \\
\hline Denmark & 14.4 & 444.0 & 6.0 & 2.3 & 12.6 & 479.3 \\
\hline Estonia & & 2.8 & 1.8 & & & 4.6 \\
\hline Finland & 8.2 & 21.2 & 4.5 & & & 34.0 \\
\hline France (mainland) + & 74.0 & $1,623.3$ & 29.5 & 3.5 & 0.8 & $1,731.1$ \\
\hline Germany & 409.9 & $10,095.4$ & $1,282.4$ & & 21.5 & $11,809.2$ \\
\hline Greece & & $2,872.9$ & 12.5 & & & $2,885.4$ \\
\hline Hungary & 9.5 & 118.1 & 35.8 & 1.3 & 1.0 & 165.6 \\
\hline India & & $3,521.7$ & 994.0 & & 14.1 & $4,529.8$ \\
\hline Ireland & & 129.2 & 61.2 & & & 190.4 \\
\hline Israel & 22.3 & $2,901.5$ & & 0.4 & & $2,924.2$ \\
\hline Italy & 30.6 & $2,048.6$ & 333.5 & & & $2,412.7$ \\
\hline Japan & & $3,064.8$ & 58.3 & & 352.1 & $3,475.2$ \\
\hline Jordan*** & 4.2 & 611.4 & 171.3 & & & 786.8 \\
\hline Korea. South & & $1,179.4$ & & & & $1,179.4$ \\
\hline Latvia & & 2.0 & 0.8 & & & 2.8 \\
\hline Lebanon*** & & 163.8 & 204.4 & & & 368.2 \\
\hline Lithuania & & 2.3 & 1.9 & & & 4.2 \\
\hline Luxembourg & & 24.5 & 3.3 & & & 27.9 \\
\hline Macedonia* & & 17.5 & 0.5 & & & 18.0 \\
\hline Malta & & 25.2 & 8.6 & & & 33.8 \\
\hline Mexico & 582.1 & 610.6 & 228.2 & 0.2 & 5.6 & $1,426.7$ \\
\hline Morocco*** & & 343.9 & & & & 343.9 \\
\hline Mozambique & & 0.2 & & & & 0.2 \\
\hline Namibia** & & 14.5 & 0.9 & & & 15.4 \\
\hline Netherlands & 293.1 & 300.2 & 11.9 & & & 605.2 \\
\hline New Zealand* & 4.9 & 100.1 & 6.8 & & & 111.8 \\
\hline Norway & 1.4 & 22.0 & 1.9 & & 2.1 & 27.4 \\
\hline Poland & & 641.6 & 206.5 & & & 848.1 \\
\hline Portugal & 1.5 & 661.9 & 15.5 & & & 678.9 \\
\hline Romania & & 56.5 & 21.0 & & & 77.5 \\
\hline Russia\# & & 12.3 & 0.9 & & & 13.2 \\
\hline Slovakia & & 88.1 & 14.8 & & & 102.9 \\
\hline Slovenia & & 117.3 & 13.5 & & & 130.8 \\
\hline South Africa & 606.8 & 266.7 & 80.9 & & & 954.5 \\
\hline Spain & 93.9 & $1,862.9$ & 117.2 & & & $2,074.0$ \\
\hline Sweden & 91.0 & 182.0 & 42.0 & & & 315.0 \\
\hline Switzerland & 148.1 & 686.7 & 51.1 & 613.3 & & $1,499.2$ \\
\hline Taiwan & 1.6 & 927.1 & 75.3 & & & $1,003.9$ \\
\hline Thailand & & 84.3 & & & & 84.3 \\
\hline Tunisia & & 415.1 & 32.3 & & & 447.5 \\
\hline Turkey & & $9,580.2$ & $1,268.4$ & & & $10,848.5$ \\
\hline United Kingdom & & 376.6 & 120.2 & 13.3 & & 510.1 \\
\hline United States & $14,311.4$ & $1,853.3$ & 82.1 & 66.7 & 14.0 & $16,327.4$ \\
\hline Uruguay** & & 8.8 & & & & 8.8 \\
\hline Zimbabwe & & 13.1 & 0.6 & & & 13.7 \\
\hline TOTAL & 22,670 & 70,983 & 174,061 & 1,142 & 447 & 269,303 \\
\hline
\end{tabular}

Note: If no data is given: no reliable database for this collector type is available. FPC: flat plate collector; ETC: evacuated tube collector

* Total capacity in operation refers to the year 2009

** Total capacity in operation refers to the year 2011

*** Total capacity in operation is based on estimations for new installations in 2012

\# New included countries compared to the 2013 edition of this report

$+\quad$ The figures for France relate to mainland France only, overseas territories of France (DOM) are not considered

Table 1: Total capacity in operation by the end of $2012\left[\mathrm{MW}_{\text {th }}\right]$ 


\begin{tabular}{|c|c|c|c|c|c|c|}
\hline \multirow{2}{*}{ Country } & \multicolumn{3}{|c|}{ Water Collectors } & \multicolumn{2}{|c|}{ Air Collectors } & \multirow{2}{*}{ TOTAL [m²] } \\
\hline & unglazed & FPC & ETC & unglazed & glazed & \\
\hline Albania & & 111,135 & 786 & & & 111,921 \\
\hline Australia & $4,350,000$ & $2,908,000$ & 68,000 & 280,000 & 7,200 & $7,613,200$ \\
\hline Austria & 558,601 & $4,289,605$ & 79,542 & & 1,908 & $4,929,656$ \\
\hline Barbados* & & 131,690 & & & & 131,690 \\
\hline Belgium & 45,000 & 329,469 & 55,064 & & & 429,533 \\
\hline Brazil & $2,314,735$ & $5,947,321$ & & & & $8,262,056$ \\
\hline Bulgaria & & 120,050 & 2,050 & & & 122,100 \\
\hline Canada & 778,102 & 61,475 & 35,695 & 349,750 & 24,140 & $1,249,162$ \\
\hline Chile*** & & 80,009 & & & & 80,009 \\
\hline China & & $17,396,732$ & $240,303,268$ & & & $257,700,000$ \\
\hline Croatia\# & & 120,000 & & & & 120,000 \\
\hline Cyprus & 2,147 & 865,269 & 23,095 & & & 890,511 \\
\hline Czech Republic & 468,000 & 335,813 & 87,925 & & & 891,738 \\
\hline Denmark & 20,515 & 634,310 & 8,584 & 3,264 & 18,000 & 684,673 \\
\hline Estonia & & 3,930 & 2,590 & & & 6,520 \\
\hline Finland & 11,779 & 30,251 & 6,472 & & & 48,502 \\
\hline France (mainland) + & 105,699 & $2,318,973$ & 42,129 & 5,053 & 1,117 & $2,472,971$ \\
\hline Germany & 585,600 & $14,422,000$ & $1,832,000$ & & 30,720 & $16,870,320$ \\
\hline Greece & & $4,104,200$ & 17,800 & & & $4,122,000$ \\
\hline Hungary & 13,500 & 168,700 & 51,100 & 1,800 & 1,450 & 236,550 \\
\hline India & & $5,031,000$ & $1,420,000$ & & 20,200 & $6,471,200$ \\
\hline Ireland & & 184,524 & 87,444 & & & 271,968 \\
\hline Israel & 31,817 & $4,145,000$ & & 550 & & $4,177,367$ \\
\hline Italy & 43,766 & $2,926,580$ & 476,420 & & & $3,446,766$ \\
\hline Japan & & $4,378,220$ & 83,340 & & 502,949 & $4,964,509$ \\
\hline Jordan*** & 5,940 & 873,420 & 244,674 & & & $1,124,034$ \\
\hline Korea, South & & $1,684,824$ & & & & $1,684,824$ \\
\hline Latvia & & 2,850 & 1,190 & & & 4,040 \\
\hline Lebanon*** & & 234,000 & 292,000 & & & 526,000 \\
\hline Lithuania & & 3,300 & 2,700 & & & 6,000 \\
\hline Luxembourg & & 35,050 & 4,750 & & & 39,800 \\
\hline Macedonia* & & 25,020 & 724 & & & 25,744 \\
\hline Malta & & 36,000 & 12,293 & & & 48,293 \\
\hline Mexico & 831,508 & 872,305 & 326,063 & 300 & 7,983 & $2,038,159$ \\
\hline Morocco*** & & 491,261 & & & & 491,261 \\
\hline Mozambique & & 273 & & & & 273 \\
\hline Namibia** & & 20,699 & 1,307 & & & 22,006 \\
\hline Netherlands & 418,783 & 428,859 & 17,000 & & & 864,642 \\
\hline New Zealand* & 7,025 & 142,975 & 9,644 & & & 159,645 \\
\hline Norway & 2,007 & 31,445 & 2,674 & & 2,961 & 39,088 \\
\hline Poland & & 916,500 & 295,000 & & & $1,211,500$ \\
\hline Portugal & 2,128 & 945,587 & 22,090 & & & 969,805 \\
\hline Romania & & 80,700 & 30,000 & & & 110,700 \\
\hline Russia\# & & 17,601 & 1,297 & & & 18,898 \\
\hline Slovakia & & 125,920 & 21,080 & & & 147,000 \\
\hline Slovenia & & 167,550 & 19,250 & & & 186,800 \\
\hline South Africa & 866,871 & 381,044 & 115,597 & & & $1,363,512$ \\
\hline Spain & 134,191 & $2,661,260$ & 167,373 & & & $2,962,824$ \\
\hline Sweden & 130,000 & 260,000 & 60,000 & & & 450,000 \\
\hline Switzerland & 211,540 & 980,970 & 72,980 & 876,154 & & $2,141,644$ \\
\hline Taiwan & 2,254 & $1,324,383$ & 107,546 & & & $1,434,183$ \\
\hline Thailand & & 120,360 & & & & 120,360 \\
\hline Tunisia & & 593,038 & 46,180 & & & 639,218 \\
\hline Turkey & & $13,685,943$ & $1,811,970$ & & & $15,497,913$ \\
\hline United Kingdom & & 537,990 & 171,683 & 19,000 & & 728,673 \\
\hline United States & $20,444,848$ & $2,647,521$ & 117,232 & 95,239 & 20,000 & $23,324,841$ \\
\hline Uruguay** & & 12,571 & & & & 12,571 \\
\hline Zimbabwe & & 18,761 & 807 & & & 19,568 \\
\hline TOTAL & $32,386,356$ & $101,404,238$ & $248,658,408$ & $1,631,110$ & 638,628 & $384,718,741$ \\
\hline
\end{tabular}

Note:

If no data is given: no reliable database for this collector type is available.

FPC: flat plate collector; ETC: evacuated tube collector

* Total capacity in operation refers to the year 2009

** Total capacity in operation refers to the year 2011

*** Total capacity in operation is based on estimations for new installations in 2012

\# New included countries compared to the 2013 edition of this report

+ The figures for France relate to mainland France only, overseas territories of France (DOM) are not considered

Table 2: Total installed collector area in operation by the end of $2012\left[\mathrm{~m}^{2}\right]$ 
The total installed capacity in operation by end of 2012 is divided into flat plate collectors (FPC): $71 \mathrm{GW}_{\text {th }}$ (101.4 million square meters), evacuated tube collectors (ETC): $174.1 \mathrm{GW}_{\text {th }}$ (248.7 million square meters), unglazed water collectors $22.7 \mathrm{GW}_{\text {th }}$ (32.4 million square meters), and glazed and unglazed air collectors: $1.6 \mathrm{GW}_{\text {th }}(2.3 \mathrm{million}$ square meters).

With a share of $65 \%$, evacuated tube collectors are the predominant solar thermal collector technology worldwide, followed by flat plate collectors with $26 \%$ and unglazed water collectors with $8 \%$. Air collectors only play a minor role in total numbers (Figure 4).

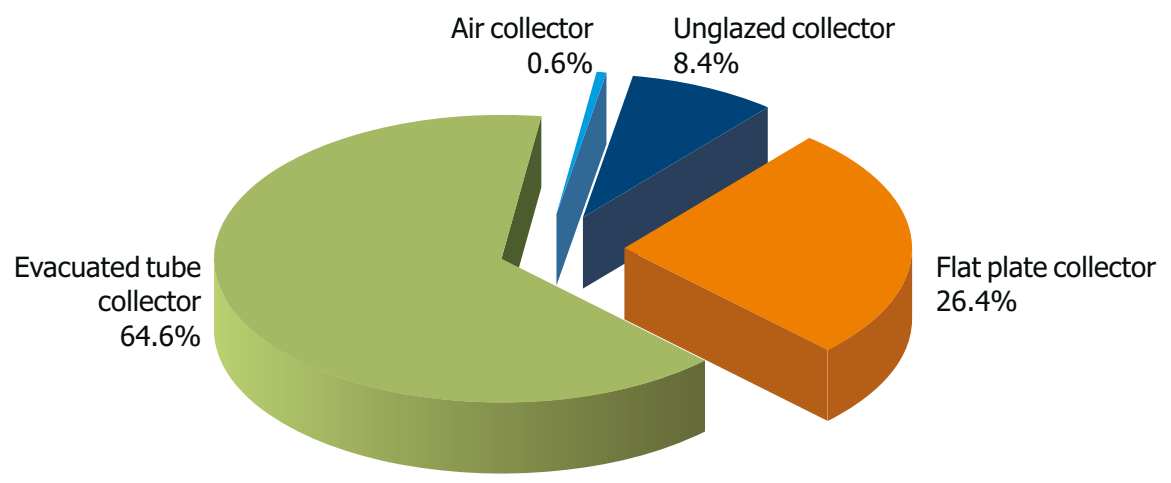

Figure 4: Distribution of the total installed capacity in operation by collector type in 2012 - WORLD

By contrast in Europe, the second largest marketplace for solar thermal collectors to China, flat plate collectors are much more widespread (Figure 5).

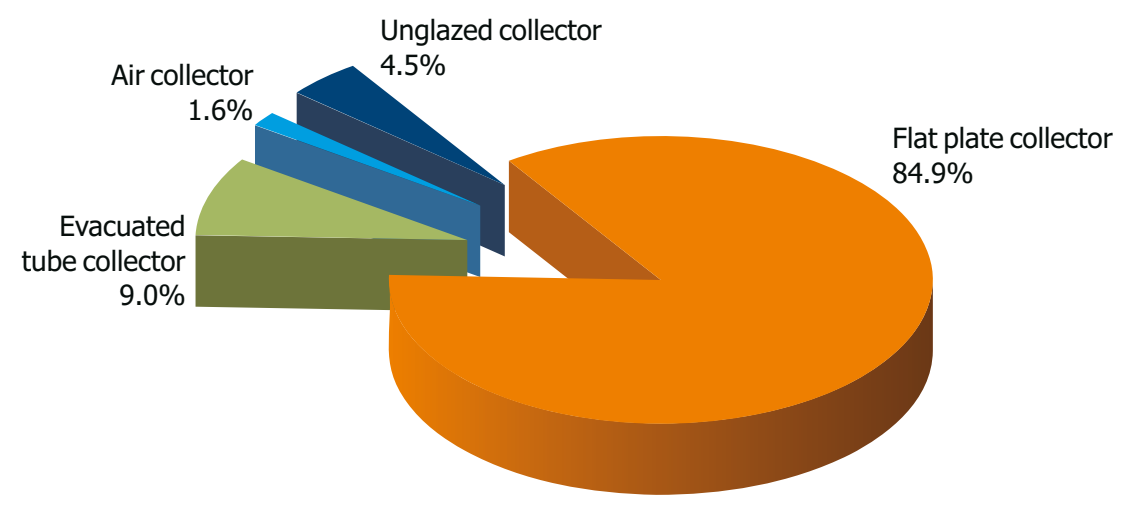

Figure 5: Distribution of the total installed capacity in operation by collector type in 2012 - EUROPE 
Figure 6 shows the cumulated installed capacity of glazed and unglazed water collectors in operation for the 10 leading markets in 2012 in total numbers. Compared to the year 2011 the ranking has remained the same.

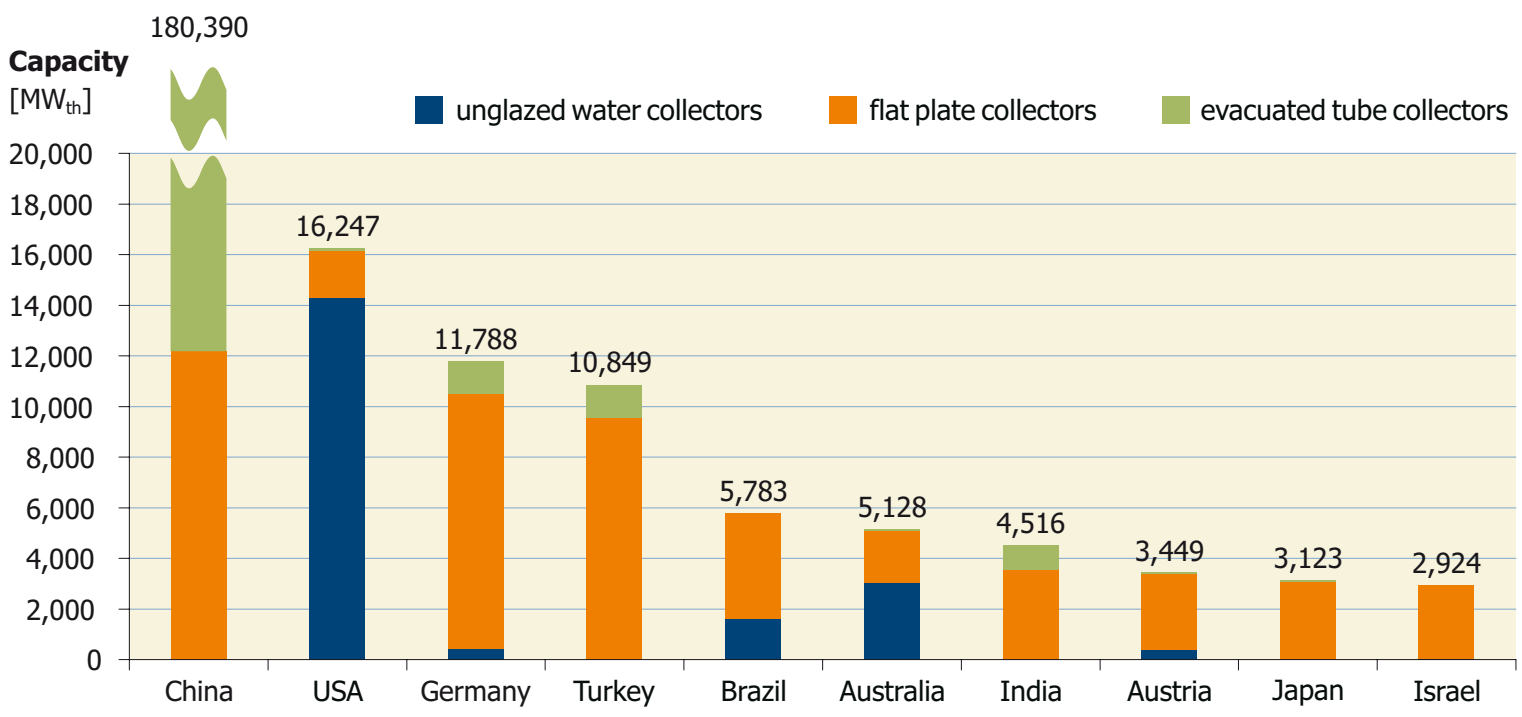

Figure 6: Top 10 countries of cumulated water collector installations (absolute figures in $\mathrm{MW}_{\mathrm{th}}$ )

China, as the world leader in total capacity, is focusing very much on evacuated tube collectors, whereas the United States is holding second position due to its high installation of unglazed water collectors. Only in Australia, and to some extent in Brazil, do unglazed water collectors also play an important role. The rest of the "Top 10 countries" are clearly focusing on flat plate collector technology.

The leading countries in cumulated unglazed and glazed water collector capacity in operation in 2012 per 1,000 inhabitants were Cyprus (548 kW th/1,000 inhabitants), Austria (420 kW th/1,000 inhabitants), Israel (385 kW th $/ 1,000$ inhabitants), Barbados (320 kW th/1,000 inhabitants), Greece (268 kW th/1,000 inhabitants), Australia (233 kW 1,000 inhabitants), Germany (145 kW $\mathrm{th} / 1,000$ inhabitants), Turkey (136 kW th/1,000 inhabitants), China (134 kW th/ 1,000 inhabitants), and Jordan (121 kW th/1,000 inhabitants).

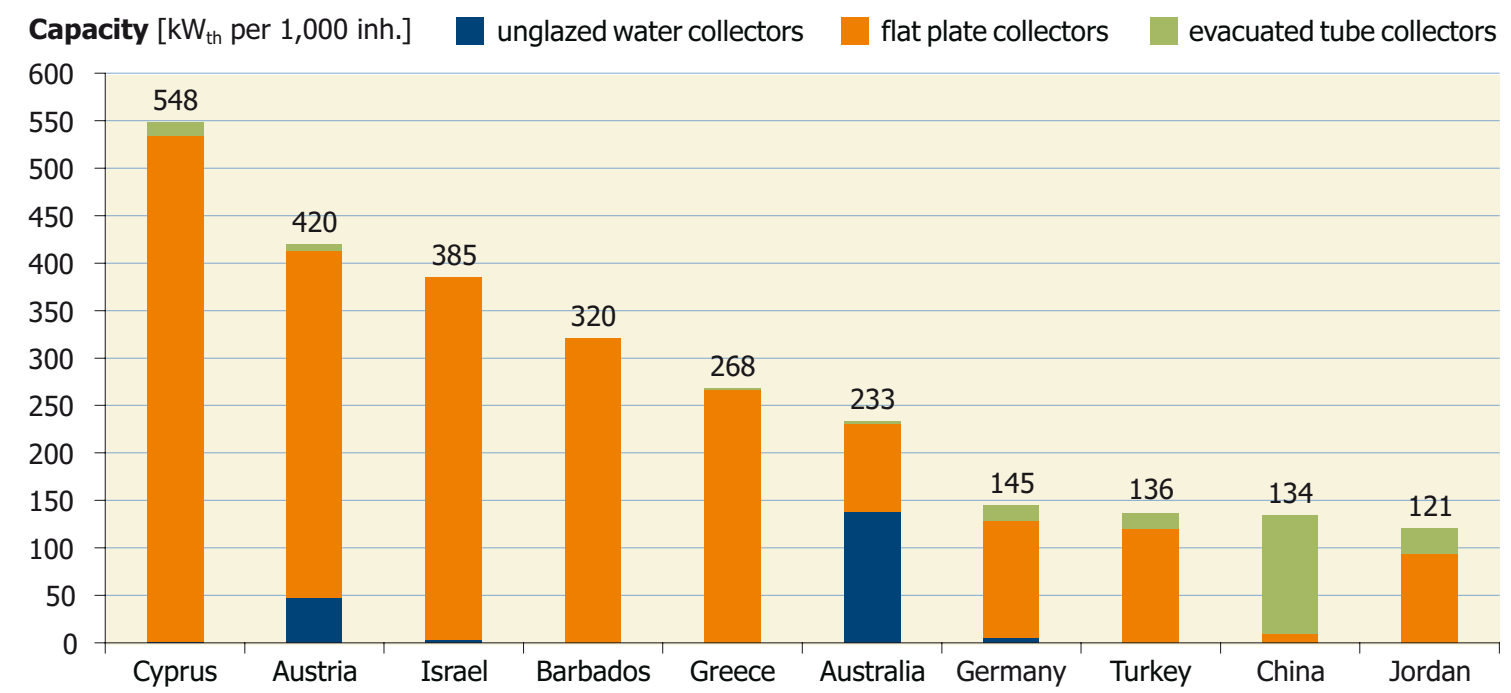

Figure 7: Top 10 countries of cumulated water collector installations (relative figures in $\mathrm{kW}_{\text {th }}$ per 1,000 inhabitants) 


\subsection{Total capacity of glazed water collectors in operation}

With more than $180 \mathrm{GW}_{\text {th }}$, China is the leader by far in terms of total installed capacity of glazed water collectors. With more than $10 \mathrm{GW}_{\text {th }}$ of installed capacity Germany and Turkey are next. Several countries, namely India, Brazil, Japan, Austria, Israel, Greece, Italy, Australia, Spain, the United States, France, South Korea, and Taiwan had more than $1 \mathrm{GW}_{\text {th }}$ of water collectors installed by end of 2012 (Figure 8).

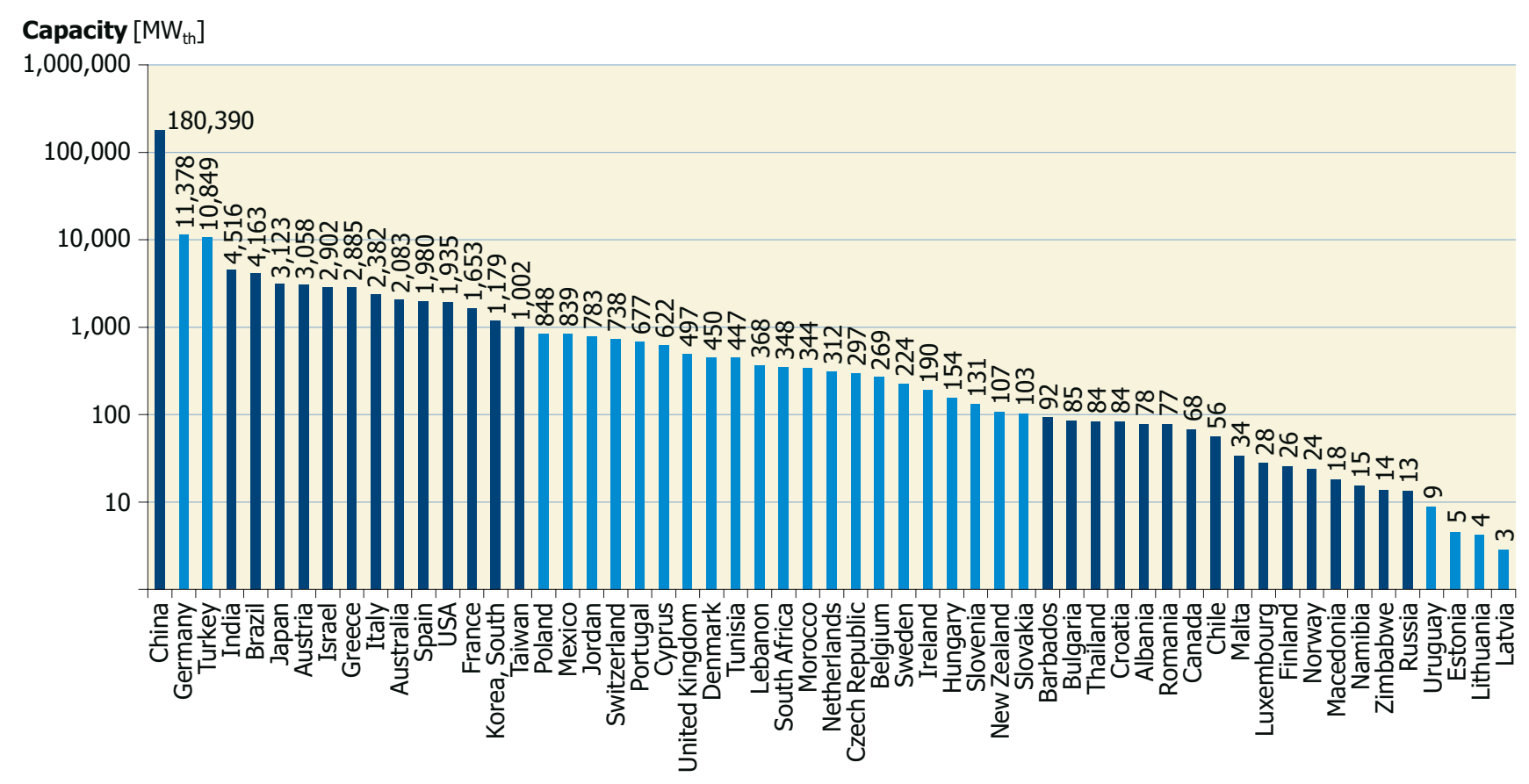

Figure 8: Total capacity of glazed water collectors in operation by the end of 2012

In terms of total installed capacity of glazed water collectors in operation per 1,000 inhabitants, there was a continued dominance by 5 countries: Cyprus ahead of Israel, Austria, Barbados and Greece. China is catching up with the Top 10 and almost reached the levels of Germany and Turkey (Figure 9).

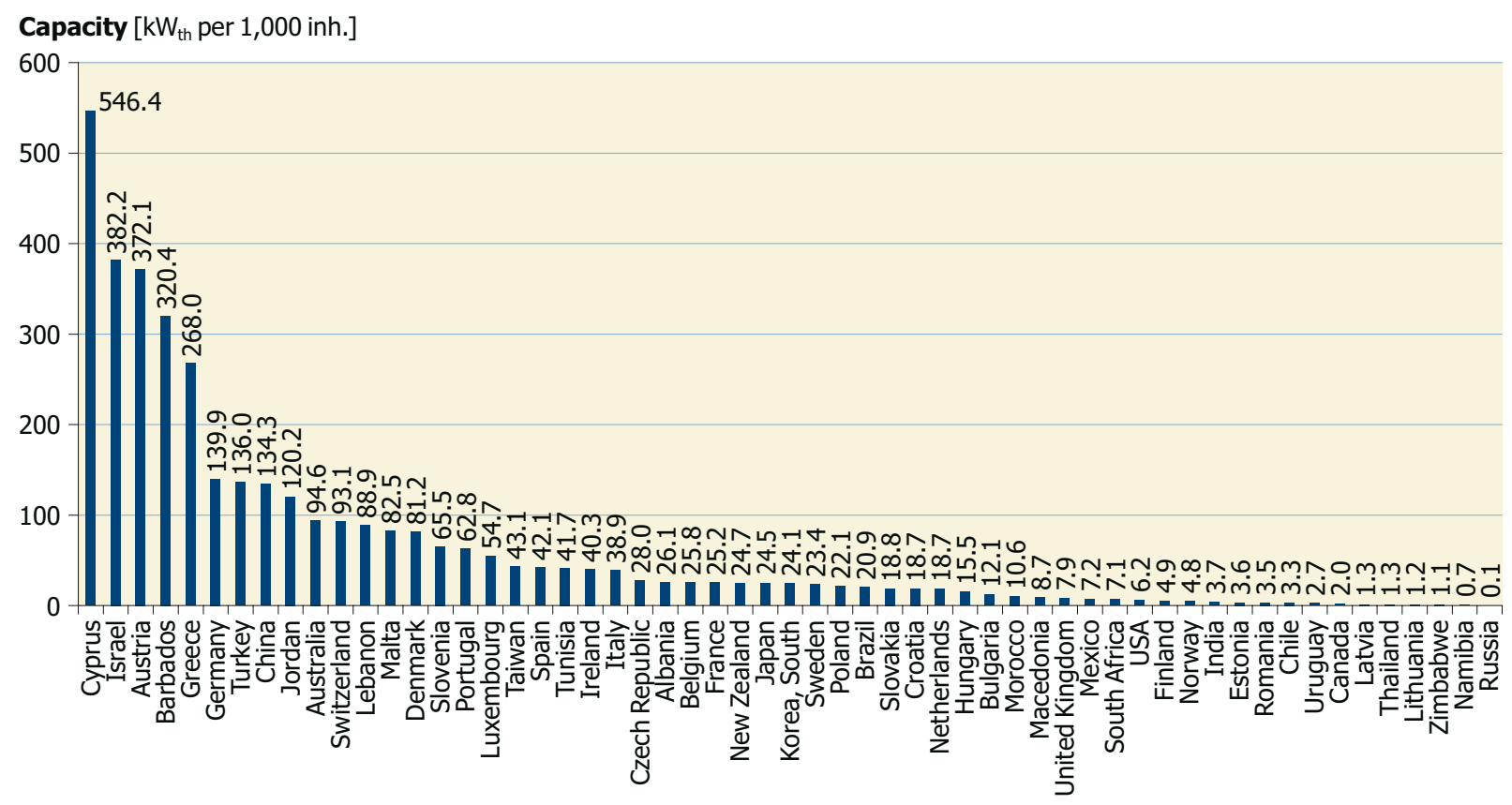

Figure 9: Total capacity of glazed water collectors in operation in $\mathrm{kW}_{\text {th }}$ per 1,000 inhabitants by the end of 2012 


\subsection{Total capacity of glazed water collectors in operation by economic region}

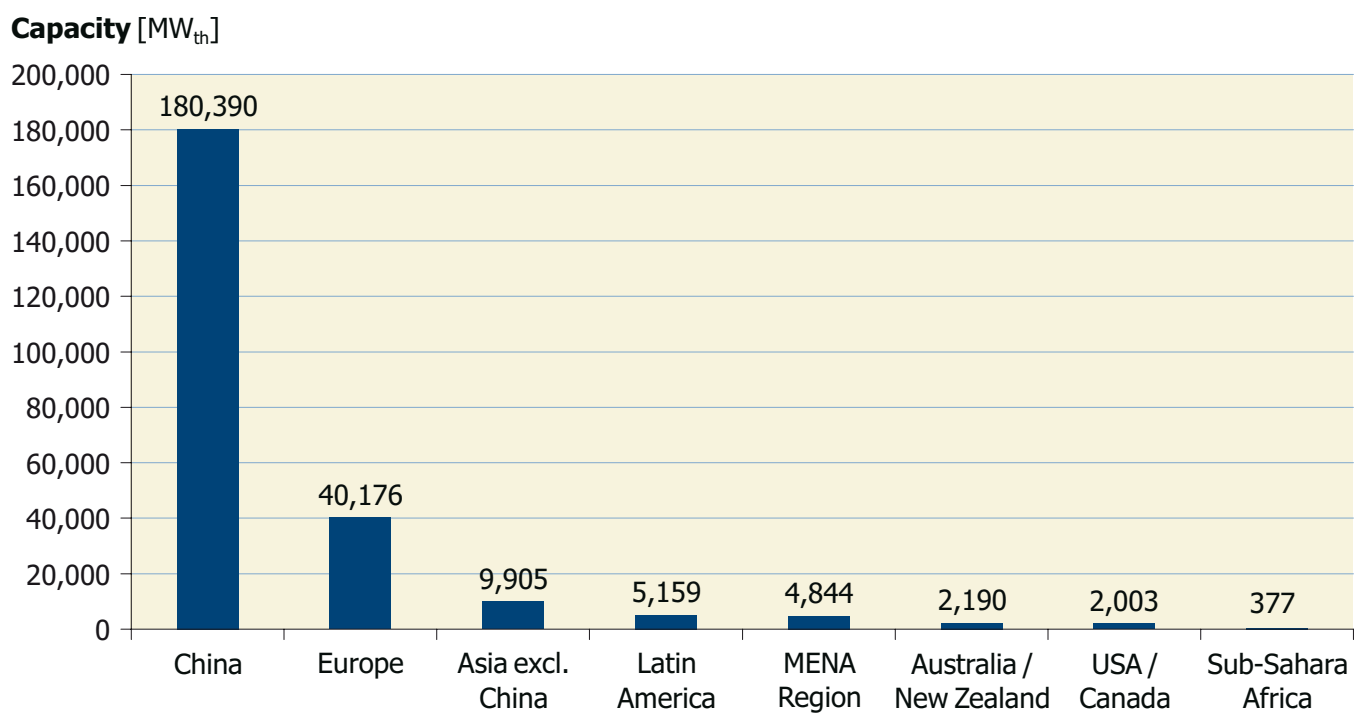

Figure 10: Total capacity of glazed flat plate and evacuated tube collectors in operation by economic region by the end of 2012

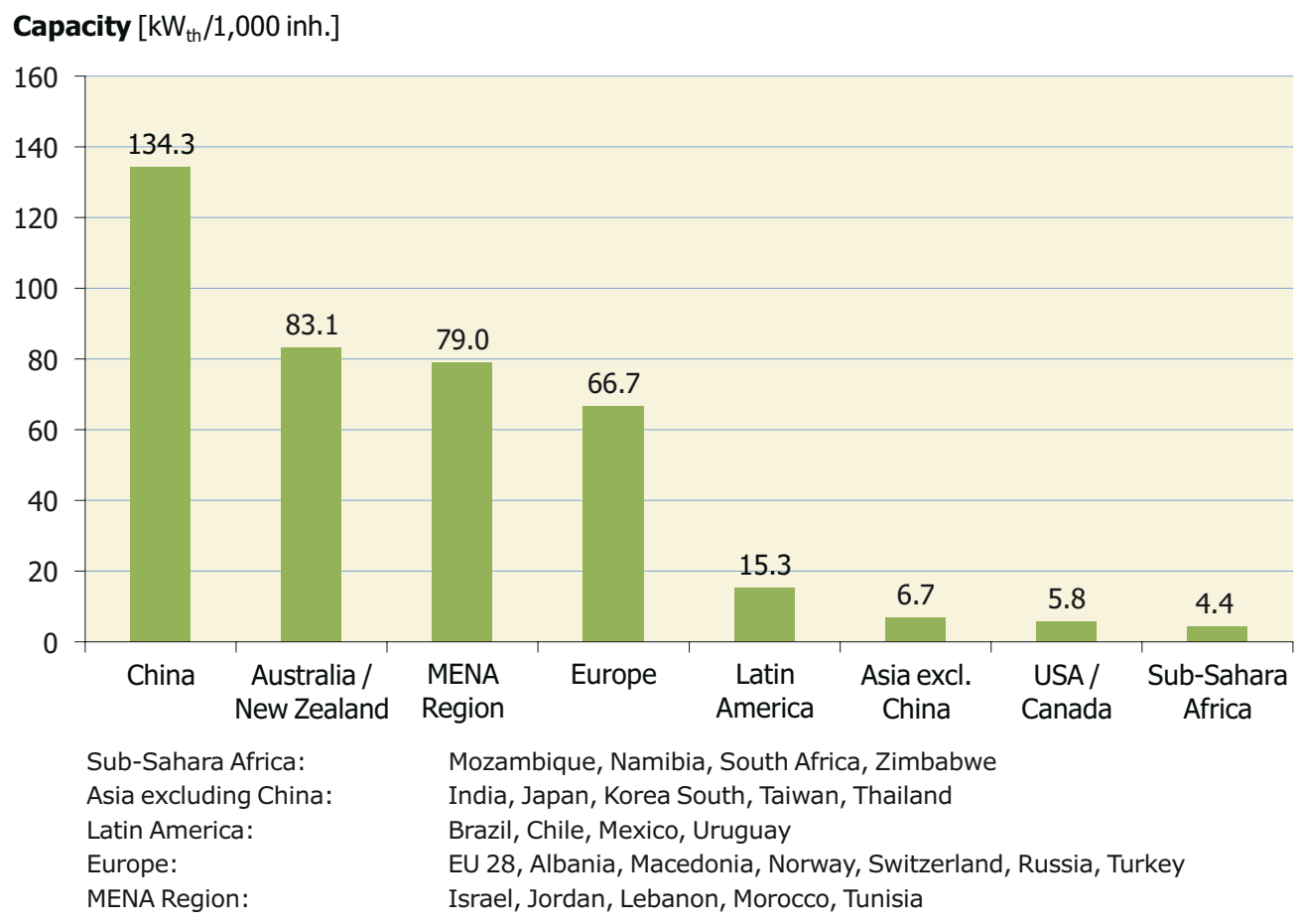

Figure 11: Total capacity of glazed flat plate and evacuated tube collectors in operation by economic region and in $\mathrm{kW}_{\text {th }}$ per 1,000 inhabitants by the end of 2012 


\subsection{Total capacity of unglazed water collectors in operation}

$84 \%$ of the total capacity of unglazed water collectors in operation is installed in three countries: the United States, Australia and Brazil (Figure 12).

Relative to the inhabitants of a country, the largest market penetration for unglazed collectors can be found in Austra-

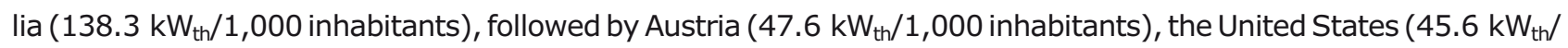
1,000 inhabitants), and the Czech Republic (30.9 kW $\mathrm{kh} / 1,000$ inhabitants).

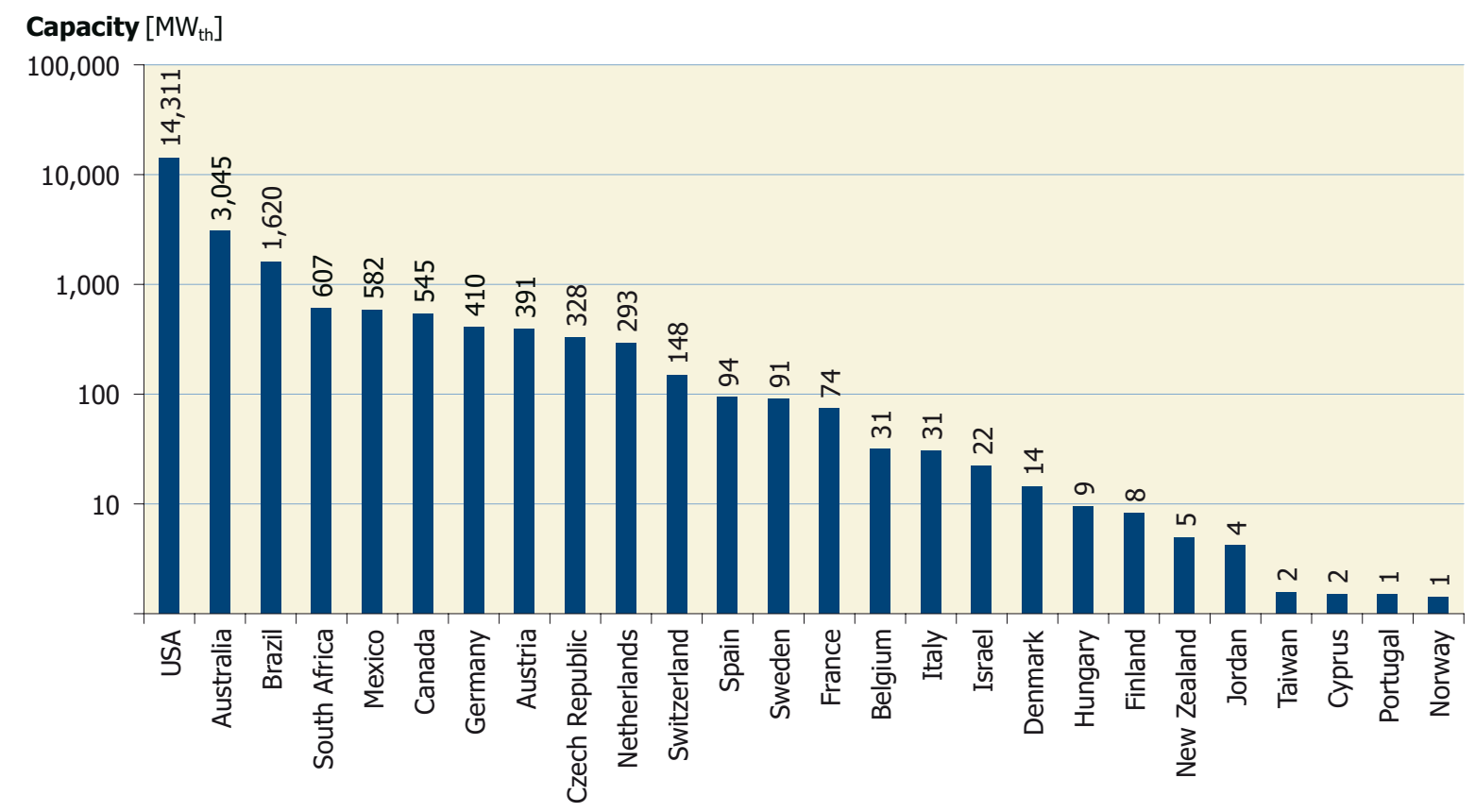

Figure 12: Total capacity of unglazed water collectors in operation by the end of 2012

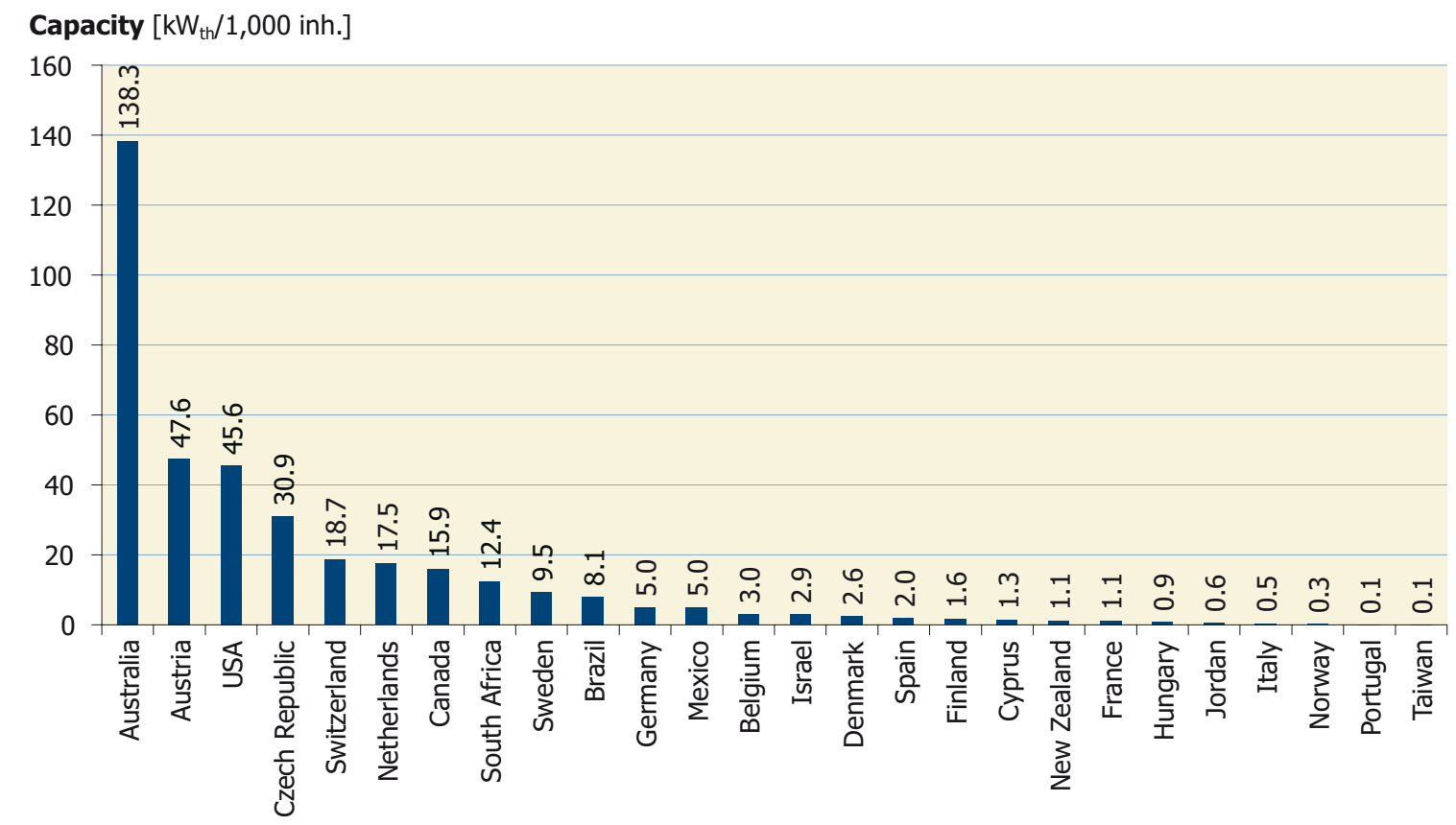

Figure 13: Total capacity of unglazed water collectors in operation in $\mathrm{kW}_{\text {th }}$ per 1,000 inhabitants by the end of 2012 


\section{Newly installed capacity in 2012 and market development}

\subsection{General market overview of newly installed capacity}

In the year 2012, a total capacity of $52.7 \mathrm{GW}_{\text {th }}$, corresponding to 75.3 million square meters of solar collectors, was installed worldwide. This means an increase in new collector installations of $9.4 \%$ compared to the year 2011. In comparison, the market growth in the period 2010/2011 amounted to $14.3 \%$.

The main markets were in China ( $44.7 \mathrm{GW}_{\text {th }}$ ) and Europe ( $3.7 \mathrm{GW}_{\text {th }}$ ), which together accounted for $92 \%$ of the overall new collector installations in 2012. The rest of the market was shared between Asia excluding China (1.3 GW $\mathrm{Gh}_{\text {th }}$, Latin America represented by Brazil, Chile and Mexico (1.0 GW th $)$, the United States and Canada ( $\left.0.8 \mathrm{GW}_{\text {th }}\right)$, Australia $\left(0.7 \mathrm{GW}_{\text {th }}\right)$, the MENA region represented by Israel, Jordan, Lebanon, Morocco and Tunisia $\left(0.4 \mathrm{GW}_{\mathrm{th}}\right)$ and the Sub-Sahara African countries Mozambique, South Africa and Zimbabwe $\left(0.1 \mathrm{GW}_{\mathrm{th}}\right)$.

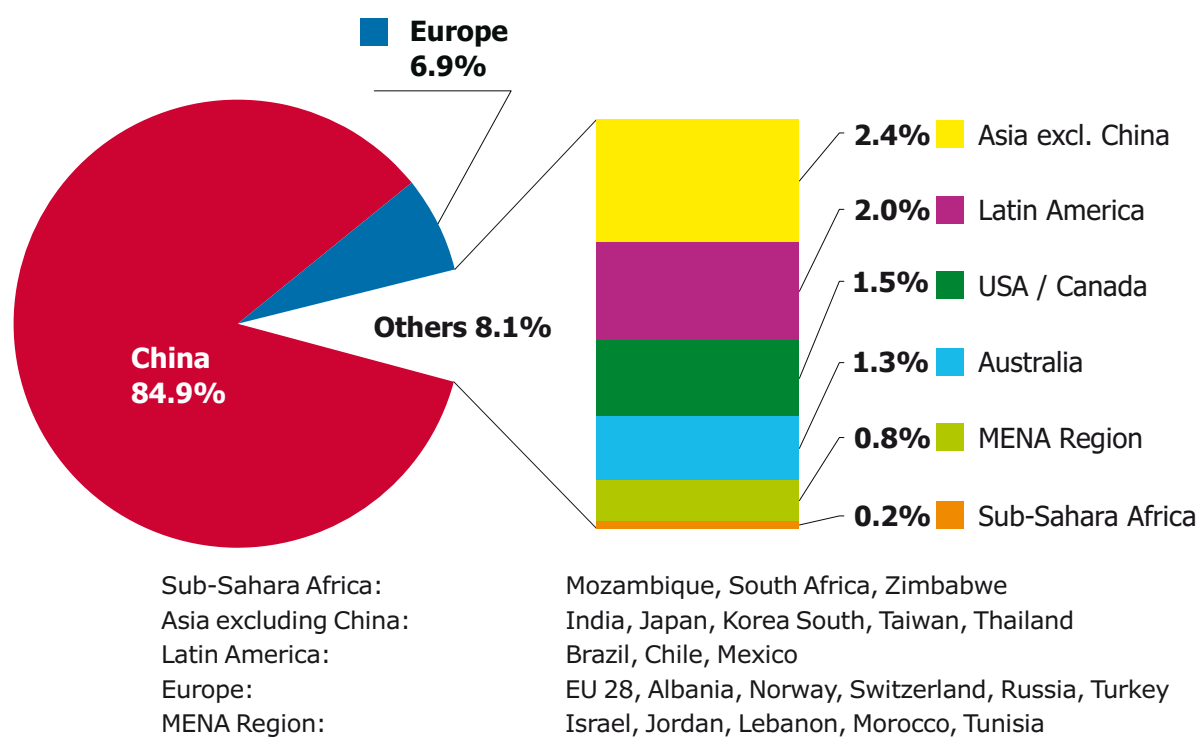

Figure 14: Share of the newly installed capacity (glazed and unglazed water and air collectors) by economic regions in 2012

The global market growth rate of $9.4 \%$ in the period $2011 / 2012$ was mainly driven by the large markets in China $(+10.9 \%)$, Brazil $(+11.8 \%)$, India $(+44.4 \%)$ and the United States $(+2.7 \%)$. In other major solar thermal markets such as in Australia $(-4.7 \%)$, Germany $(-9.5 \%)$, Israel $(-16.5 \%)$, Italy $(-15.4 \%)$, and Turkey $(-10.1 \%)$ declines were recorded.

In terms of economic regions, there was positive market growth in the period 2011/2012 in Asia, Latin America and the United States whereas in Sub-Sahara Africa, Australia, Europe and the MENA region solar thermal system installations dropped.

In China, the growth rates between 2000 and 2011 were on average around $23 \%$ and since then have been leveling off $(+17.6 \%$ in $2010 / 2011,+10.6 \%$ in $2011 / 2012,+3.3 \%$ in $2012 / 2013)$. 


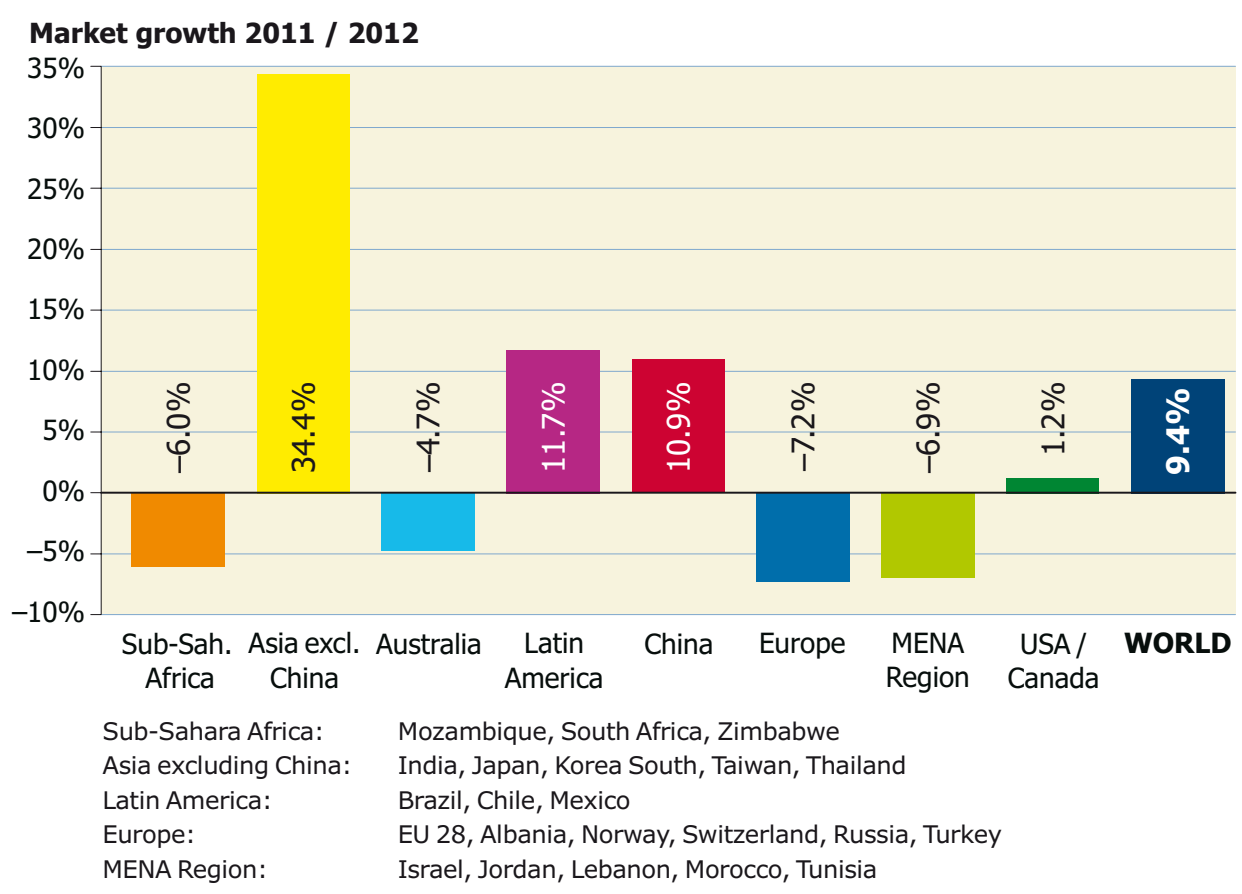

Figure 15: Market growth of newly installed capacity between 2011 and 2012 by economic region

Of all the Asian countries covered in this report, positive market figures were reported for China $(+10.9 \%)$, India $(+44.4 \%)$, Japan $(+1.2 \%)$, South Korea $(+16.5 \%)$, Taiwan $(+5.5 \%)$, and Thailand $(+19.9 \%)$.

In Latin American, countries with positive market growth were Brazil $(+11.8 \%)$, Chile $(+15 \%)$ and Mexico $(+11.0 \%)$.

The market decline in Sub-Sahara Africa is mainly caused by the $6.7 \%$ reduction of new installations in South Africa.

Israel, the largest and most mature market in the MENA region, reported a negative growth rate of $-16.5 \%$ for 2012 .

Of the top 10 European countries only four countries-Poland, France, Greece and Denmark-reported a positive growth rate. A significant decrease of $-7.2 \%$ was reported for all of Europe with the larger markets Turkey, Germany, Italy, Spain, Austria and Switzerland experiencing significant market declines.

The United States and Canada experienced a market growth of $16.1 \%$ in 2009/2010 followed by a significant decrease of $-21.7 \%$ in $2010 / 2011$, and recovered again in 2011/2012 (+1.2\%)

In Australia, the market for water collectors declined for a third year in a row, $-5.4 \%$ in the period 2009/2010, $-10.4 \%$ in the period $2010 / 2011$, and $-4.7 \%$ in the period 2011/2012. 


\begin{tabular}{|c|c|c|c|c|c|c|}
\hline \multirow{2}{*}{ Country } & \multicolumn{3}{|c|}{ Water Collectors } & \multicolumn{2}{|c|}{ Air Collectors } & \multirow{2}{*}{ TOTAL $\left[\mathrm{MW}_{\mathrm{th}}\right]$} \\
\hline & unglazed & FPC & ETC & unglazed & glazed & \\
\hline Albania & & 14.7 & 0.1 & & & 14.8 \\
\hline Australia & 455.0 & 167.6 & 21.3 & 24.5 & 0.7 & 669.1 \\
\hline Austria & 1.7 & 140.6 & 3.9 & & 0.6 & 146.7 \\
\hline Belgium & & 35.4 & 8.1 & & & 43.4 \\
\hline Brazil & 367.9 & 438.1 & & & & 806.0 \\
\hline Bulgaria & & 5.2 & 0.4 & & & 5.6 \\
\hline Canada & 50.1 & 4.6 & 5.5 & 11.1 & 8.7 & 79.8 \\
\hline Chile* & & 15.3 & & & & 15.3 \\
\hline China & & $3,500.0$ & $41,230.0$ & & & $44,730.0$ \\
\hline Croatia \# & & 9.6 & & & & 9.6 \\
\hline Cyprus & 0.0 & 14.5 & 1.0 & & & 15.5 \\
\hline Czech Republic & 35.0 & 25.9 & 9.1 & & & 70.0 \\
\hline Denmark & & 78.8 & 0.4 & & & 79.1 \\
\hline Estonia & & 0.6 & 0.6 & & & 1.3 \\
\hline Finland & & 2.1 & 0.7 & & & 2.8 \\
\hline France (mainland) + & & 168.5 & 6.1 & 3.2 & 0.7 & 178.5 \\
\hline Germany & & 725.2 & 79.8 & & & 805.0 \\
\hline Greece & & 169.1 & 1.1 & & & 170.1 \\
\hline Hungary & 1.1 & 24.5 & 10.5 & 0.2 & 0.2 & 36.4 \\
\hline India & & 374.5 & 640.5 & & 5.6 & $1,020.6$ \\
\hline Ireland & & 13.0 & 5.7 & & & 18.7 \\
\hline Israel & 0.8 & 217.4 & & & & 218.2 \\
\hline Italy & & 198.7 & 32.3 & & & 231.0 \\
\hline Japan & & 111.1 & 2.2 & & 5.6 & 118.9 \\
\hline Jordan* & & 38.2 & 9.6 & & & 47.8 \\
\hline Korea, South & & 44.6 & & & & 44.6 \\
\hline Latvia & & 0.1 & 0.1 & & & 0.2 \\
\hline Lebanon* & & 30.8 & 15.4 & & & 46.2 \\
\hline Lithuania & & 0.4 & 0.8 & & & 1.3 \\
\hline Luxembourg & & 2.3 & 0.6 & & & 2.9 \\
\hline Malta & & 1.0 & 0.4 & & & 1.4 \\
\hline Mexico & 76.7 & 66.7 & 66.7 & & & 210.0 \\
\hline Morocco* & & 55.0 & & & & 55.0 \\
\hline Mozambique & & & 0.1 & & & 0.1 \\
\hline Netherlands & 19.2 & 19.6 & 5.6 & & & 44.4 \\
\hline Norway & & 10.7 & 0.6 & & 1.4 & 12.6 \\
\hline Poland & & 151.2 & 60.2 & & & 211.4 \\
\hline Portugal & 0.1 & 58.5 & 5.0 & & & 63.6 \\
\hline Romania & & 6.0 & 4.9 & & & 10.9 \\
\hline Russia \# & & 4.3 & 0.2 & & & 4.5 \\
\hline Slovakia & & 4.6 & 0.7 & & & 5.3 \\
\hline Slovenia & & 9.5 & 2.1 & & & 11.6 \\
\hline South Africa & 34.3 & 15.5 & 35.2 & & & 85.1 \\
\hline Spain & 2.5 & 147.7 & 8.8 & & & 159.1 \\
\hline Sweden & 0.6 & 5.8 & 2.1 & & & 8.5 \\
\hline Switzerland & 8.3 & 87.9 & 12.1 & & & 108.3 \\
\hline Taiwan & 0.0 & 74.0 & 8.3 & & & 82.3 \\
\hline Thailand & & 15.9 & & & & 15.9 \\
\hline Tunisia & & 52.0 & 1.5 & & & 53.5 \\
\hline Turkey & & 802.4 & 334.6 & & & $1,137.0$ \\
\hline United Kingdom & & 33.5 & 8.0 & 3.5 & & 45.0 \\
\hline United States & 530.2 & 160.8 & 8.4 & 10.5 & 9.8 & 719.7 \\
\hline Zimbabwe & & 0.6 & 0.4 & & & 1.0 \\
\hline TOTAL & $1,583.4$ & $8,354.1$ & $42,651.7$ & 52.9 & 33.2 & $52,675.3$ \\
\hline
\end{tabular}

Note: If no data is given: no reliable database for this collector type is available. FPC: flat plate collector; ETC: evacuated tube collector

No data from Barbados, Macedonia, Namibia, New Zealand and Uruguay

* Country market data for new installations in 2012 estimated by AEE INTEC

\# New included countries compared to the 2012 edition of this report

$+\quad$ The figures for France relate to mainland France only, overseas territories of France (DOM) are not considered

Table 3: newly installed capacity in 2012 [ $\left[\mathrm{MW}_{\mathrm{th}} / \mathrm{a}\right]$ 


\begin{tabular}{|c|c|c|c|c|c|c|}
\hline \multirow{2}{*}{ Country } & \multicolumn{3}{|c|}{ Water Collectors } & \multicolumn{2}{|c|}{ Air Collectors } & \multirow{2}{*}{ TOTAL $\left[\mathrm{m}^{2}\right]$} \\
\hline & unglazed & FPC & ETC & unglazed & glazed & \\
\hline Albania & & 21,060 & 140 & & & 21,200 \\
\hline Australia & 650,000 & 239,400 & 30,450 & 35,000 & 1,000 & 955,850 \\
\hline Austria & 2,410 & 200,800 & 5,590 & & 830 & 209,630 \\
\hline Belgium & & 50,500 & 11,500 & & & 62,000 \\
\hline Brazil & 525,508 & 625,855 & & & & $1,151,363$ \\
\hline Bulgaria & & 7,400 & 600 & & & 8,000 \\
\hline Canada & 71,510 & 6,513 & 7,812 & 15,824 & 12,359 & 114,018 \\
\hline Chile* & & 21,893 & & & & 21,893 \\
\hline China & & $5,000,000$ & $58,900,000$ & & & $63,900,000$ \\
\hline Croatia \# & & 13,750 & & & & 13,750 \\
\hline Cyprus & 24 & 20,646 & 1,439 & & & 22,109 \\
\hline Czech Republic & 50,000 & 37,000 & 13,000 & & & 100,000 \\
\hline Denmark & & 112,500 & 500 & & & 113,000 \\
\hline Estonia & & 900 & 900 & & & 1,800 \\
\hline Finland & & 3,000 & 1,000 & & & 4,000 \\
\hline France (mainland) & & 240,750 & 8,750 & 4,500 & 1,000 & 255,000 \\
\hline Germany & & $1,036,000$ & 114,000 & & & $1,150,000$ \\
\hline Greece & & 241,500 & 1,500 & & & 243,000 \\
\hline Hungary & 1,500 & 35,000 & 15,000 & 300 & 250 & 52,050 \\
\hline India & & 535,000 & 915,000 & & 8,000 & $1,458,000$ \\
\hline Ireland & & 18,516 & 8,148 & & & 26,664 \\
\hline Israel & 1,200 & 310,500 & & & & 311,700 \\
\hline Italy & & 283,800 & 46,200 & & & 330,000 \\
\hline Japan & & 158,741 & 3,208 & & 7,950 & 169,899 \\
\hline Jordan* & & 54,531 & 13,705 & & & 68,236 \\
\hline Korea, South & & 63,774 & & & & 63,774 \\
\hline Latvia & & 150 & 150 & & & 300 \\
\hline Lebanon* & & 44,000 & 22,000 & & & 66,000 \\
\hline Lithuania & & 600 & 1,200 & & & 1,800 \\
\hline Luxembourg & & 3,250 & 900 & & & 4,150 \\
\hline Malta & & 1,499 & 510 & & & 2,009 \\
\hline Mexico & 109,500 & 95,250 & 95,250 & & & 300,000 \\
\hline Morocco* & & 78,572 & & & & 78,572 \\
\hline Mozambique & & & 143 & & & 143 \\
\hline Netherlands & 27,396 & 27,972 & 8,000 & & & 63,368 \\
\hline Norway & & 15,236 & 795 & & 1,983 & 18,014 \\
\hline Poland & & 216,000 & 86,000 & & & 302,000 \\
\hline Portugal & 182 & 83,624 & 7,090 & & & 90,896 \\
\hline Romania & & 8,500 & 7,000 & & & 15,500 \\
\hline Russia \# & & 6,097 & 287 & & & 6,384 \\
\hline Slovakia & & 6,500 & 1,000 & & & 7,500 \\
\hline Slovenia & & 13,500 & 3,000 & & & 16,500 \\
\hline South Africa & 49,068 & 22,176 & 50,344 & & & 121,588 \\
\hline Spain & 3,591 & 211,060 & 12,623 & & & 227,274 \\
\hline Sweden & 910 & 8,251 & 3,006 & & & 12,167 \\
\hline Switzerland & 11,815 & 125,609 & 17,287 & & & 154,711 \\
\hline Taiwan & 5 & 105,698 & 11,848 & & & 117,551 \\
\hline Thailand & & 22,660 & & & & 22,660 \\
\hline Tunisia & & 74,238 & 2,180 & & & 76,418 \\
\hline Turkey & & $1,146,298$ & 478,000 & & & $1,624,298$ \\
\hline United Kingdom & & 47,893 & 11,382 & 5,000 & & 64,275 \\
\hline United States & 757,400 & 229,700 & 12,000 & 15,000 & 14,000 & $1,028,100$ \\
\hline Zimbabwe & & 802 & 570 & & & 1,372 \\
\hline TOTAL & $2,262,019$ & $11,934,463$ & $60,931,007$ & 75,624 & 47,372 & $75,250,486$ \\
\hline
\end{tabular}

Note: If no data is given: no reliable database for this collector type is available. FPC: flat plate collector; ETC: evacuated tube collector

No data from Barbados, Macedonia, Namibia, New Zealand and Uruguay

* Country market data for new installations in 2012 estimated by AEE INTEC

\# $\quad$ New included countries compared to the 2012 edition of this report

$+\quad$ The figures for France relate to mainland France only, overseas territories of France (DOM) are not considered

Table 4: New Installed collector area in 2012 [m²/a]

New installations in 2012 are divided into flat plate collectors: $8.4 \mathrm{GW}_{\text {th }}$ (12.0 million square meters), evacuated tube collectors: $42.7 \mathrm{GW}_{\text {th }}$ (60.9 million square meters), unglazed water collectors: $1.6 \mathrm{GW}_{\text {th }}$ (2.3 million square meters,) and glazed and unglazed air collectors: $0.09 \mathrm{GW}_{\text {th }}$ ( 0.12 million square meters). 
With a share of $81 \%$, evacuated tube collectors are by far the most important solar thermal collector technology worldwide (Figure 16). In a global context this breakdown is mainly driven by the dominance of the Chinese market where more than $86 \%$ of all newly installed collectors in 2012 were evacuated tube collectors.

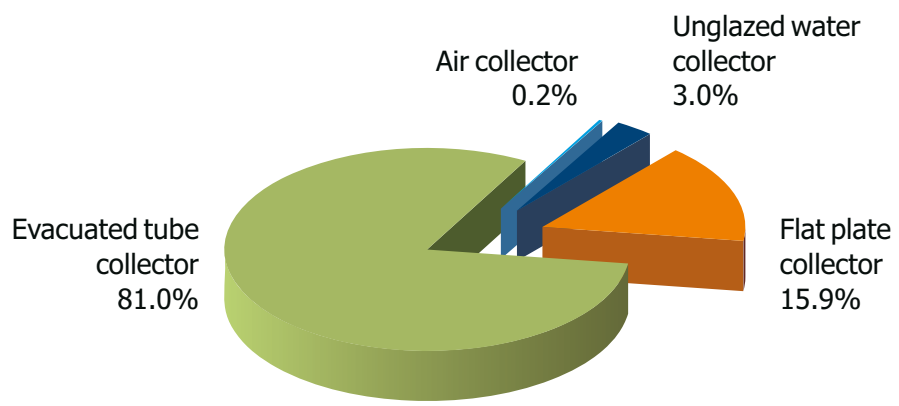

Figure 16: Distribution of the newly installed capacity by collector type in 2012 - WORLD

By contrast, in Europe the situation is almost the opposite with more than $86 \%$ of all solar thermal systems installed in 2012 being flat plate collectors (Figure 17).

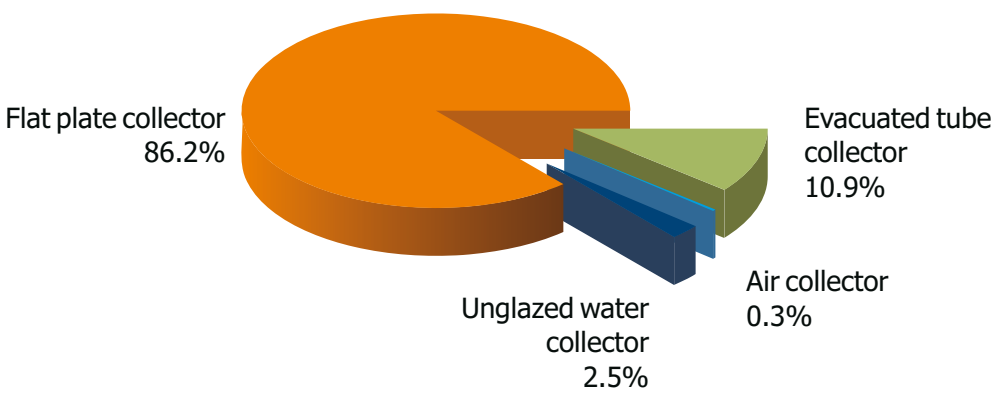

Figure 17: Distribution of the newly installed capacity by collector type in 2012 - EUROPE

Figure 18 shows the newly installed capacity of glazed and unglazed water collectors for the 10 leading markets in 2012 in total numbers. Compared to the newly installed capacity in 2011, China remained the market leader in absolute terms followed by Turkey.

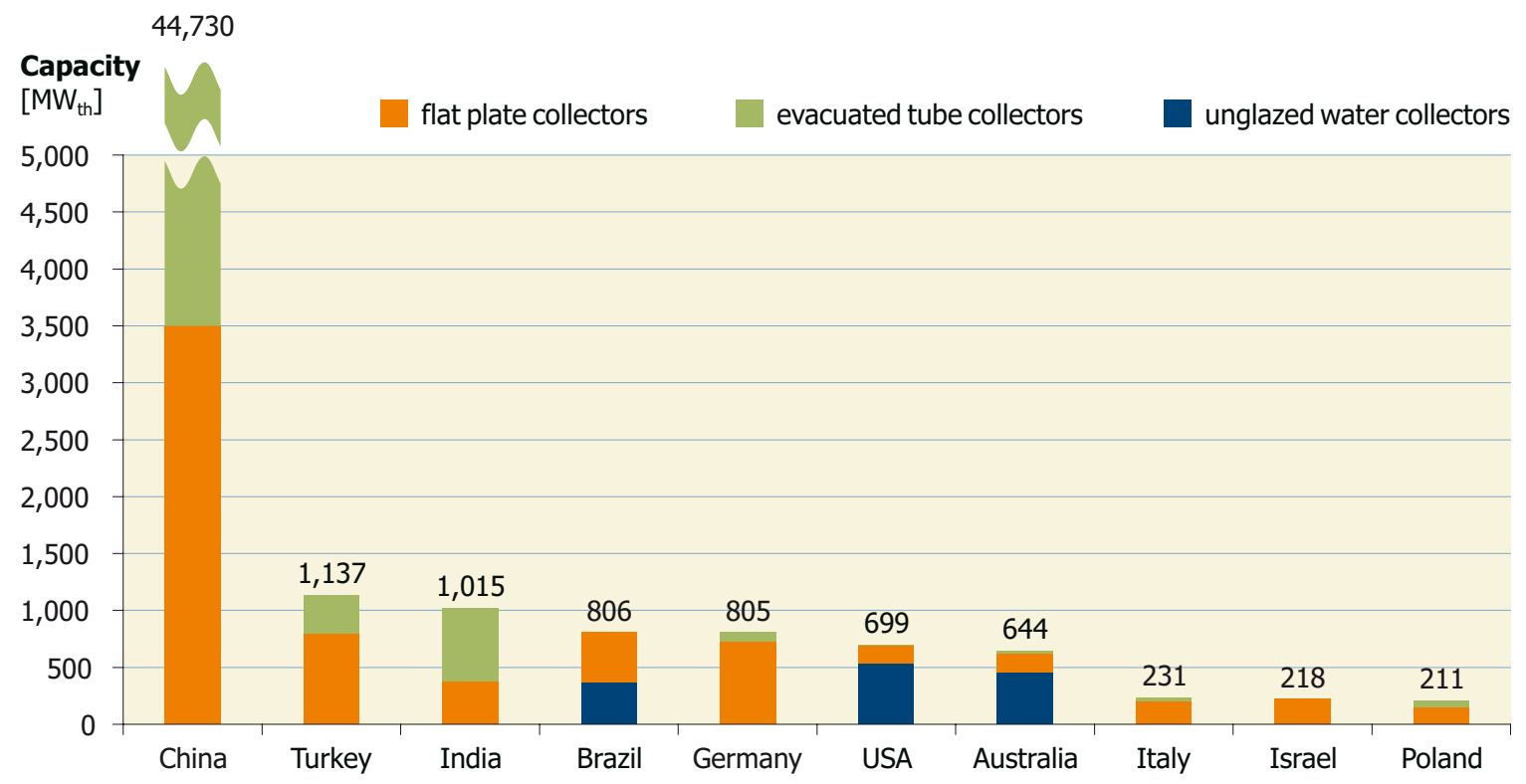

Figure 18: Top 10 markets for glazed and unglazed water collectors in 2012 (absolute figures in $M W_{\text {th }}$ ) 
Germany faced a significant market decline in 2012 and hence fell behind India and Brazil within the top 10 ranking. Poland entered the top 10 in 2012 as one of the most dynamic markets in Europe in recent years replacing Spain where the market has halved over the last four years.

As illustrated in Figure 19 China is leading as well with a remarkable $33.3 \mathrm{~kW}_{\text {th }}$ of newly installed solar thermal capacity per 1,000 inhabitants in 2012 ahead of Australia, Israel, Austria and Greece.

Denmark is ranked in sixth position, but it is worth mentioning that the majority of the Danish systems are large scale $\left(>5,000 \mathrm{~m}^{2}\right)$ and hydraulically connected to district heating systems (see Chapter 7.2).

By contrast, Australia is ranked second, which is mainly due to the country's large market share of unglazed water collectors that are used primarily for swimming pool heating.

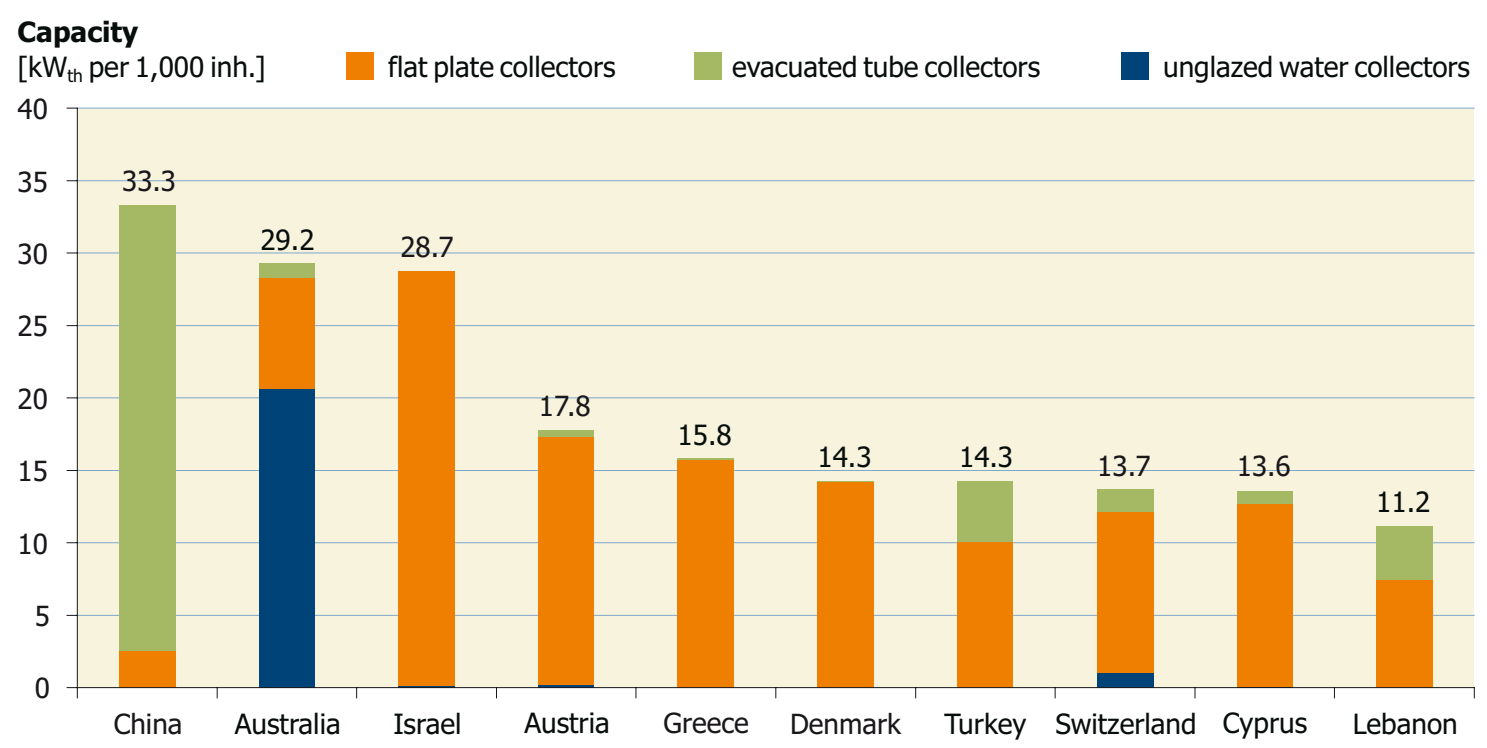

Figure 19: Top 10 markets for glazed and unglazed water collectors in 2012 (relative figures in $\mathrm{kW}_{\text {th }}$ per 1,000 inhabitants) 


\subsection{Newly installed capacity of glazed water collectors}

In 2012 glazed water collectors (evacuated tube and flat plate collectors) accounted for $96.8 \%$ of the total installed capacity (Figure 16).

For glazed water collectors, the solar thermal market in 2012 grew by $9.6 \%$ with China once again as the strong driver of this positive development. Within the top 10 glazed water heater markets Germany fell behind India in 2012 and Poland passed Australia and Spain (Figure 20).

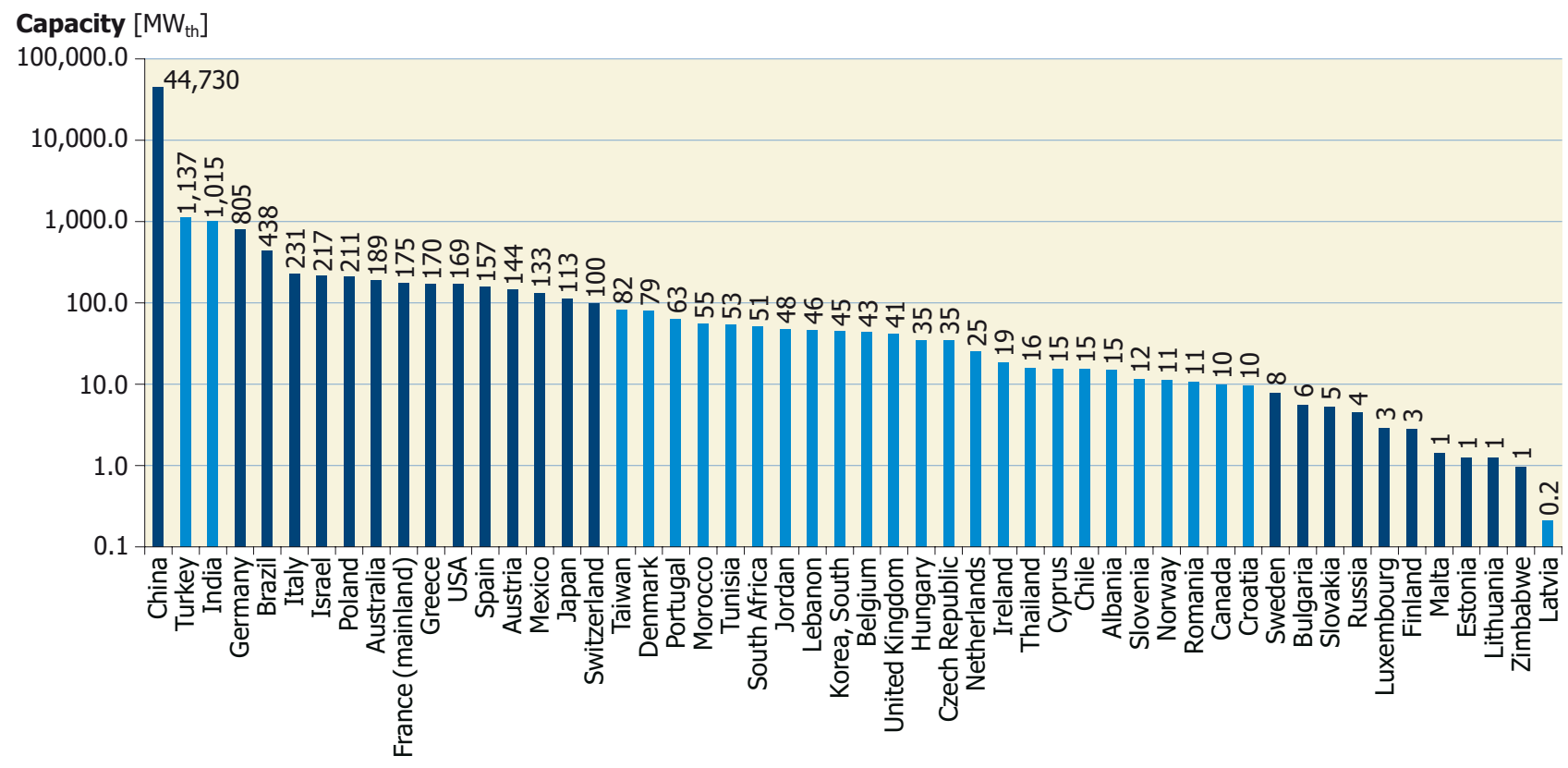

Figure 20: Newly installed capacity of glazed water collectors in 2012

In terms of newly installed glazed water collector capacity per 1,000 inhabitants, China is the leader ahead of Israel and Austria. Compared to the year 2011, Cyprus fell behind Greece, Denmark and Turkey (Figure 21).

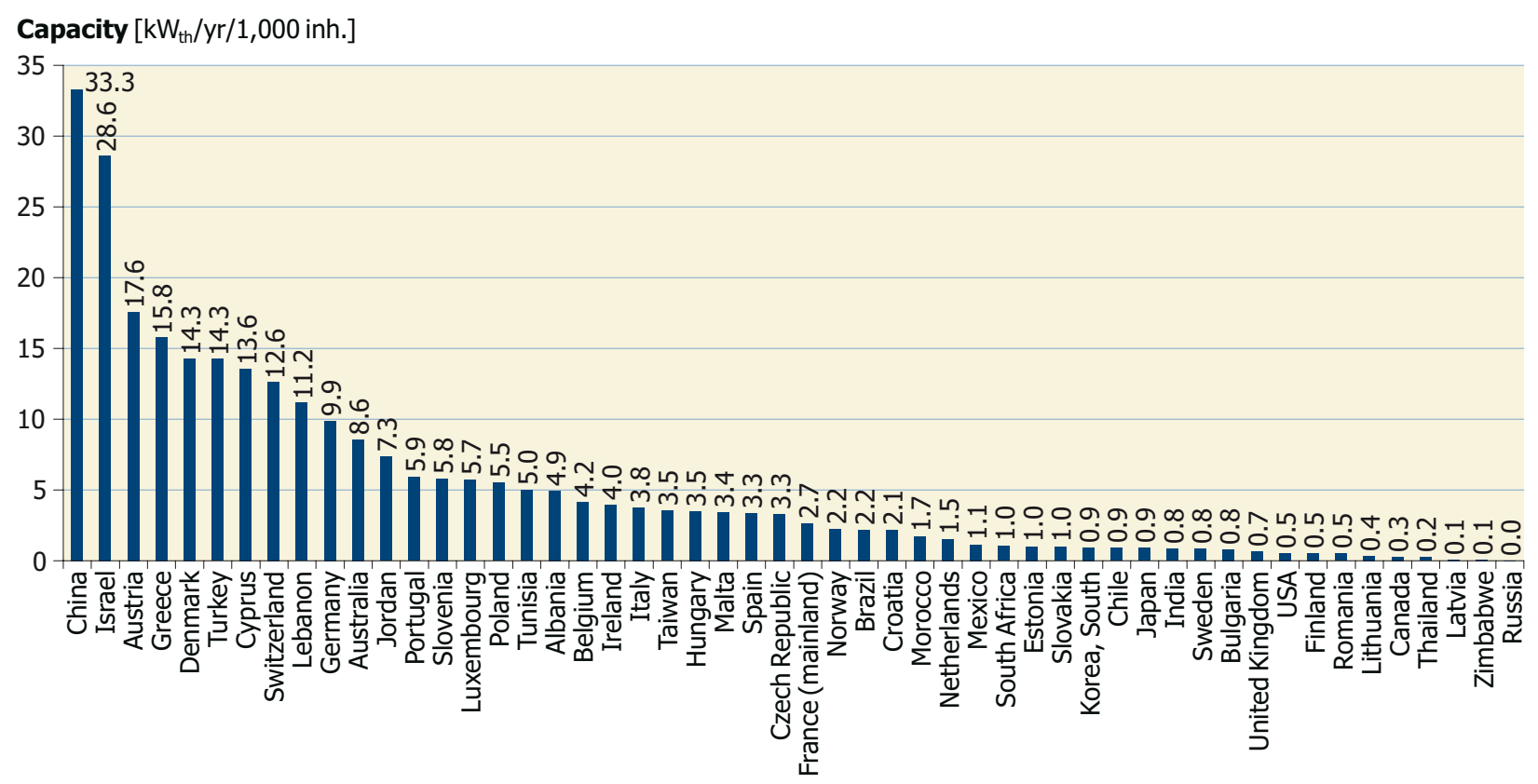

Figure 21: Newly installed capacity of glazed water collectors in 2012 in $\mathrm{kW}_{\text {th }}$ per 1,000 inhabitants 


\subsection{Market development of glazed water collectors between 2000 and 2012}

The worldwide market of glazed water collectors is characterized by a steady growth over the past 12 years with China as the main driver for this positive development. Between 2000 and 2012, the average growth rate worldwide was around 20\% and between 2006 and 2012 the annual installed glazed water collector area worldwide tripled. Compared to the year 2011, the growth rate has dropped from $15.3 \%$ to $9.6 \%$ in 2012 (Figure 22).

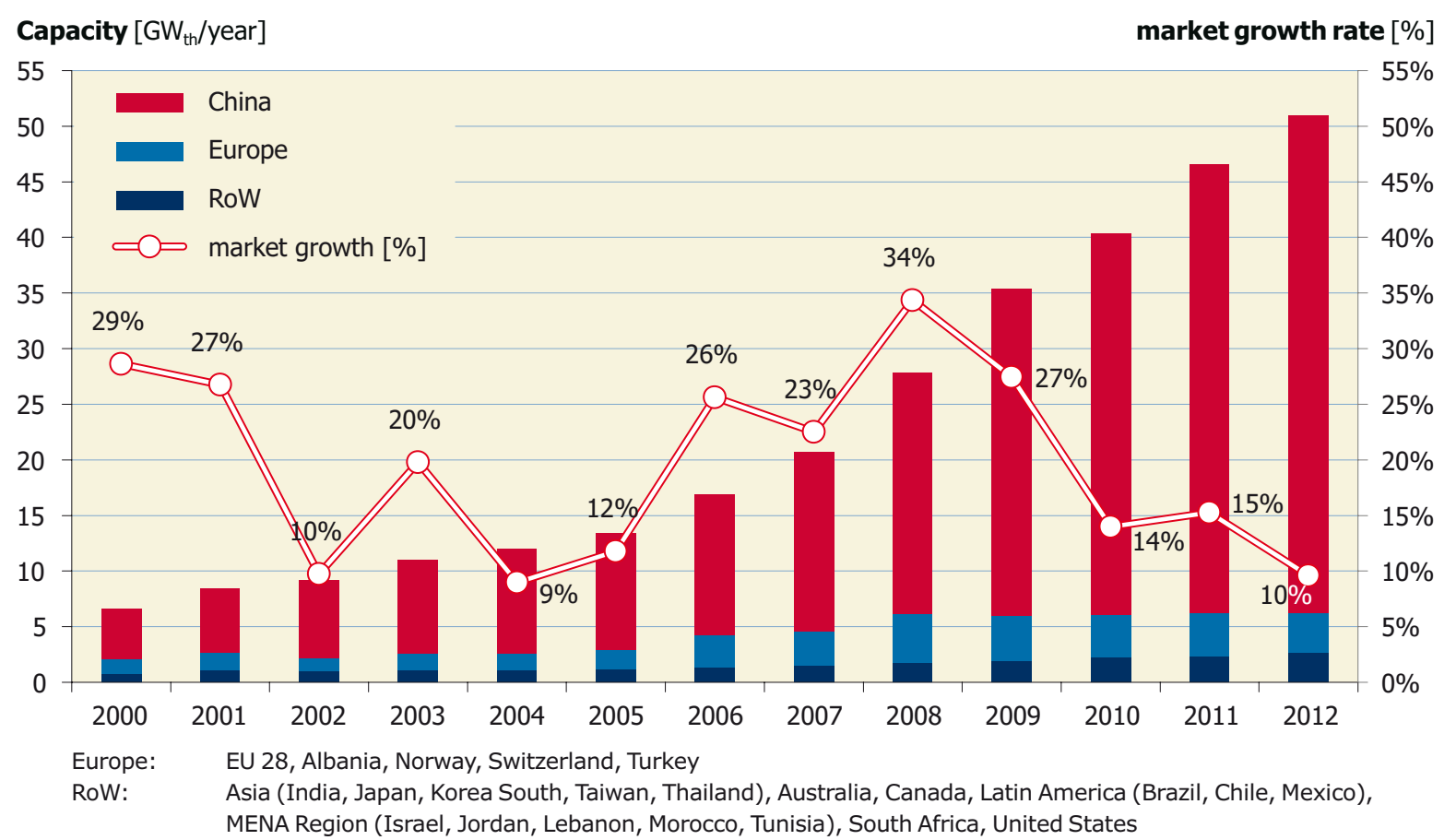

Figure 22: Global market development of glazed water collectors from 2000 to 2012

In 2000 the Chinese market was about three times as large as the European market while in 2012 the Chinese market volume exceeded it 13-fold (Figure 23).

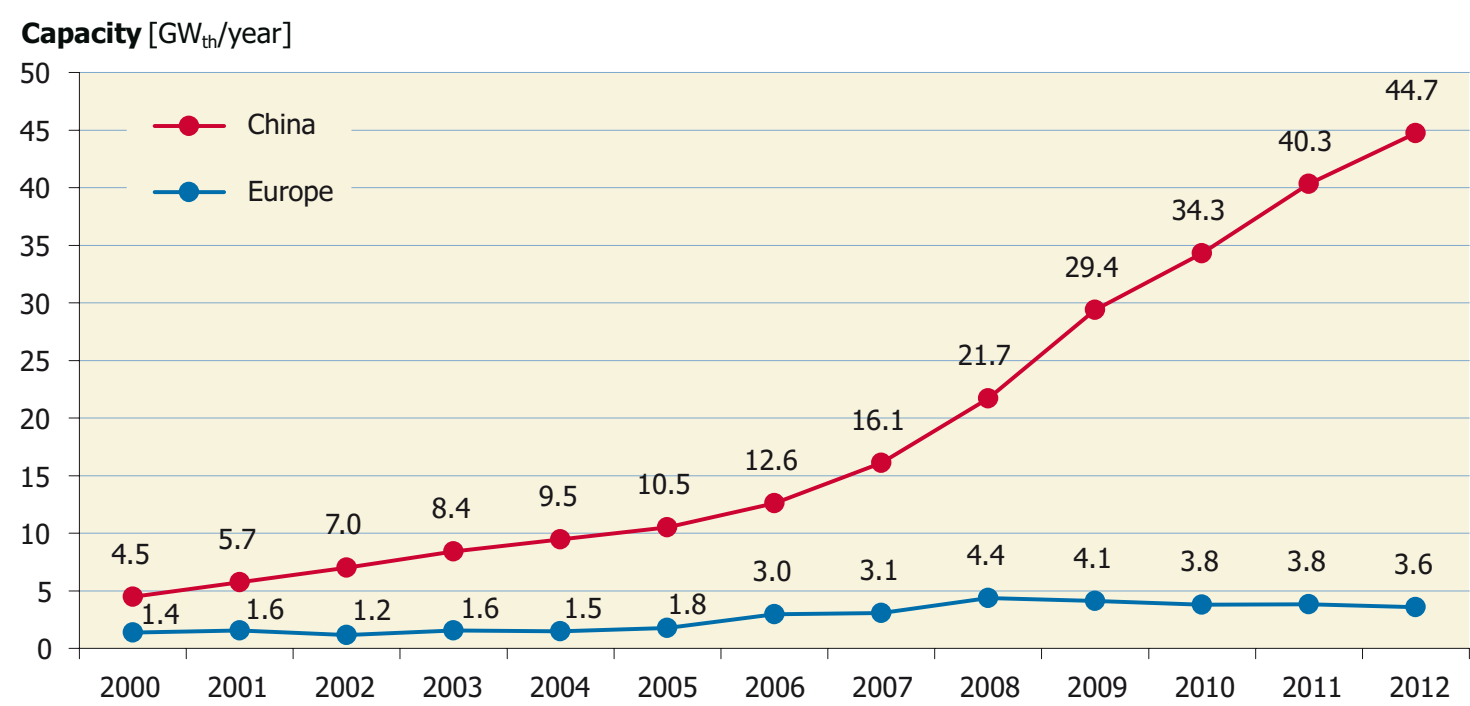

Figure 23: Market development of glazed water collectors in China and Europe 
In 2008 the European market peaked and since then the market has been declining. By contrast, in the remaining markets worldwide an upwards trend can be observed (indicated as RoW (Rest of World) in Figure 24).

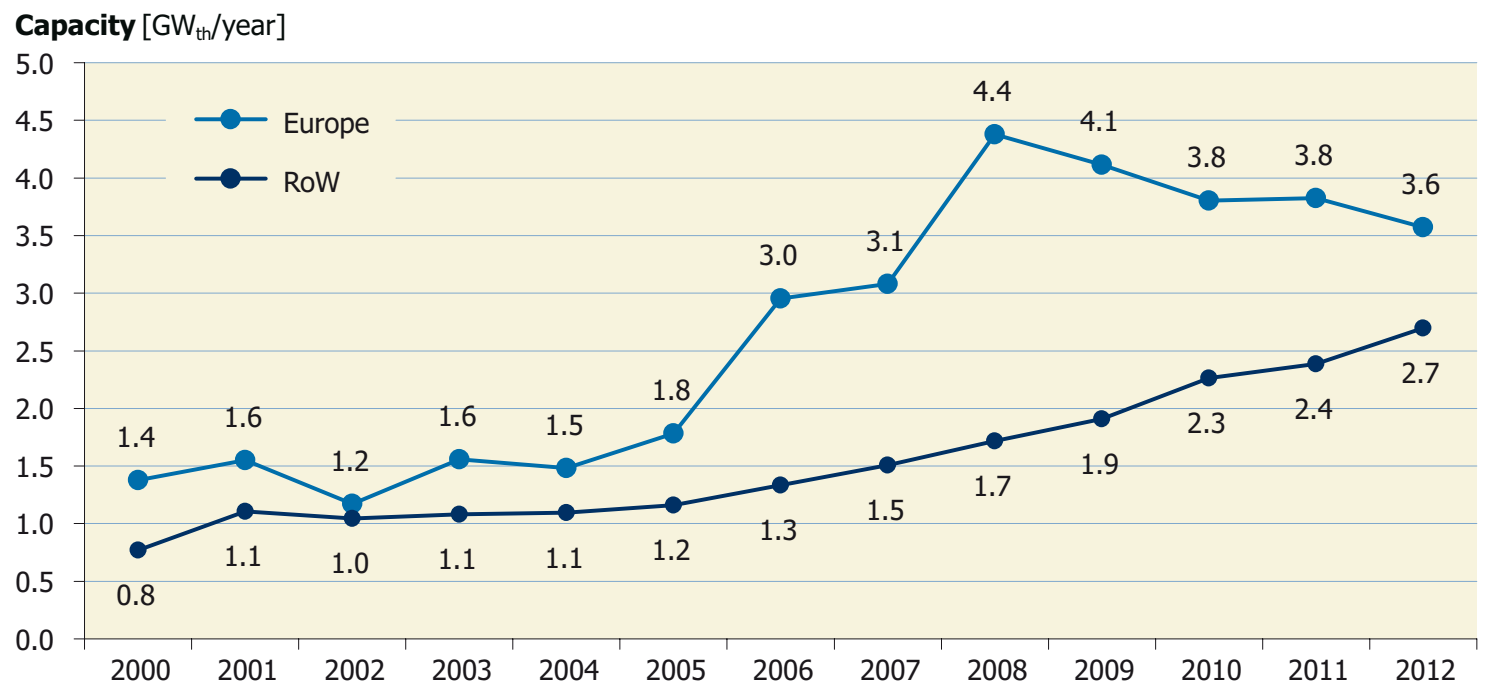

Figure 24: Market development of glazed water collectors in Europe and the Rest of World (excluding China)

RoW includes all economic regions other than China and Europe (Figure 25). Of these countries, Asia (excluding China) and Latin America hold the largest market shares and both regions show a steady upwards trend mainly due to the developments in India and Brazil.

In 2012 the MENA region saw a 16.5\% decrease in its largest market, Israel, which holds more than $50 \%$ of the solar thermal capacity installed. Also South Africa, the only country with a considerable solar thermal market in Sub-Sahara Africa, reported a market decline of $6.7 \%$ in 2012.

The Australian market has seen a significant market decline since 2009. The annual installed capacity almost halved from $364 \mathrm{MW}_{\text {th }}$ in 2009 to $189 \mathrm{MW}_{\text {th }}$ in 2012. In the United States and Canada, the market for glazed water collectors has more or less stagnated, since 2008.

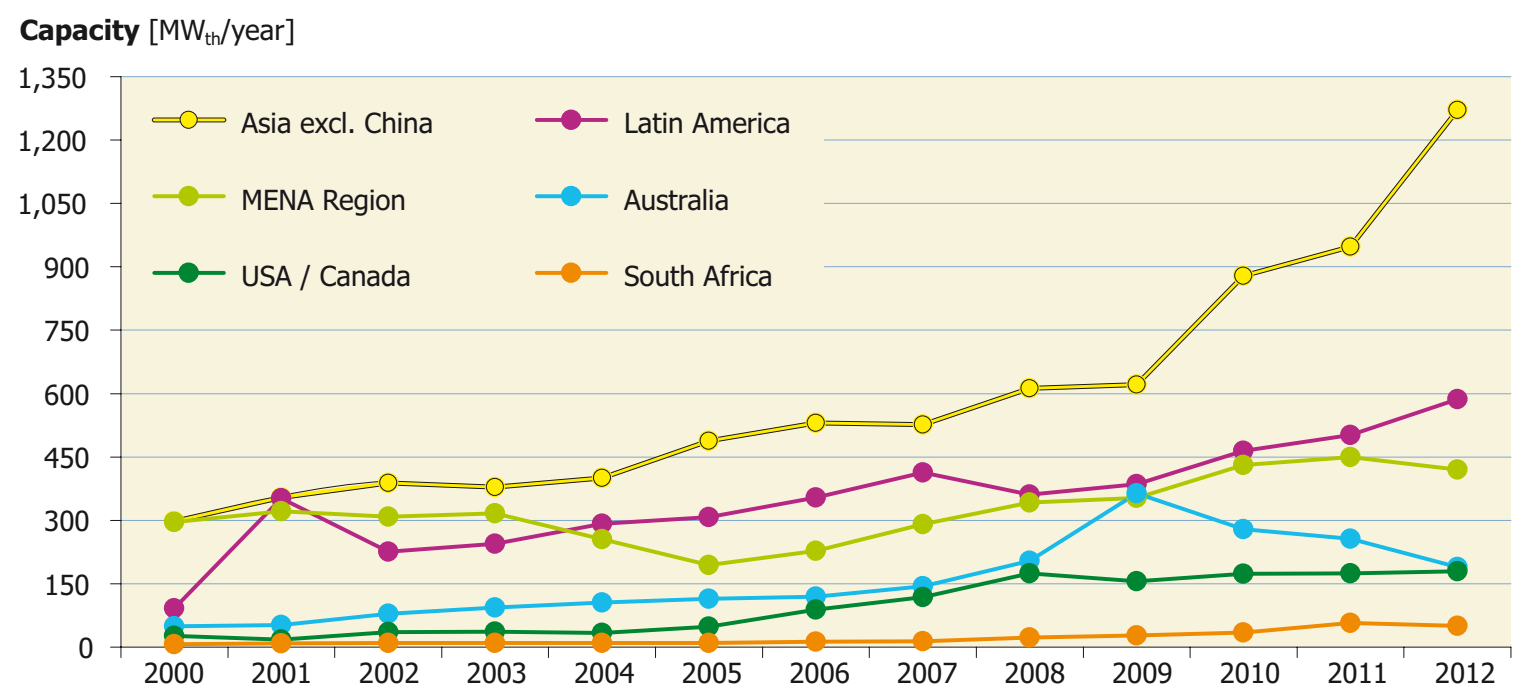

Figure 25: Market development of glazed water collectors in Rest of World (excluding China and Europe) 
In relative figures, the annual global market volume for glazed water collectors grew from $1.8 \mathrm{~kW}$ th per 1,000 inhabitants in 2000 to $12.0 \mathrm{~kW}_{\text {th }}$ per 1,000 inhabitants in 2012 (Figure 26).

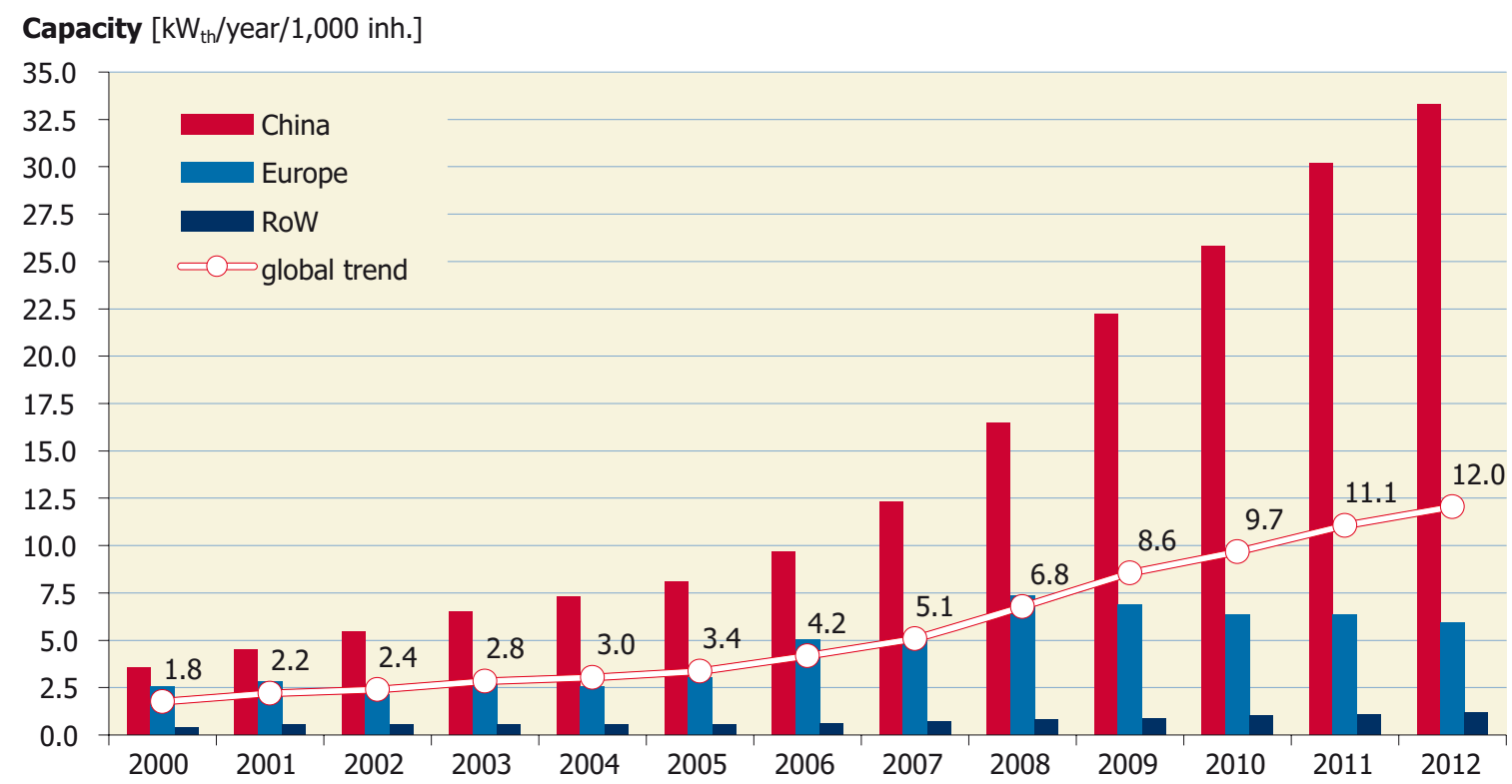

Figure 26: Annual installed capacity of glazed water collectors in kW th per 1,000 inhabitants from 2000 to 2012

It can be noted that in 2012 China has the highest market penetration in terms of glazed water collector installations per capita not only compared to other economic regions, but also compared to all other countries covered in this report. The annual installed capacity rose from $3.5 \mathrm{~kW}_{\text {th }}$ per 1,000 inhabitants in 2000 to $33.3 \mathrm{~kW}$ th per 1,000 inhabitants in 2012. Worldwide, only Israel shows a comparable market penetration of $28.6 \mathrm{~kW}_{\text {th }}$ per 1,000 inhabitants in 2012 as can be seen in Figure 21.

In Europe, the market penetration peaked in 2008 with $7.4 \mathrm{~kW}_{\text {th }}$ per 1,000 inhabitants and since then a constant downwards trend in per capita installations can be observed leading to a value of $5.9 \mathrm{~kW}_{\text {th }}$ per 1,000 inhabitants in 2012.

The other economic regions showed a slow, but steady upwards trend at a low market penetration level. Here, the annual installed capacity rose from $0.4 \mathrm{~kW}_{\text {th }}$ per 1,000 inhabitants in 2000 to $1.2 \mathrm{~kW}_{\text {th }}$ per 1,000 inhabitants in 2012.

\subsection{Market development of unglazed water collectors between 2000 and 2012}

In 2012 unglazed water collectors accounted for 3.0\% of the total installed capacity (Figure 16) and compared to the year 2011 the market grew moderately by $2.1 \%$.

The most important markets for unglazed collectors in 2012 were the United States (530 MW th), Australia (455 $\mathrm{MW}_{\text {th }}$ ), and Brazil (368 $\mathrm{MW}_{\text {th }}$ ). The three countries accounted for $85 \%$ of the recorded unglazed water collector installations. Another 14\% were installed in Mexico, Canada, the Czech Republic, South Africa, and the Netherlands. Only $1 \%$ was installed in other countries (Figure 27 ). 


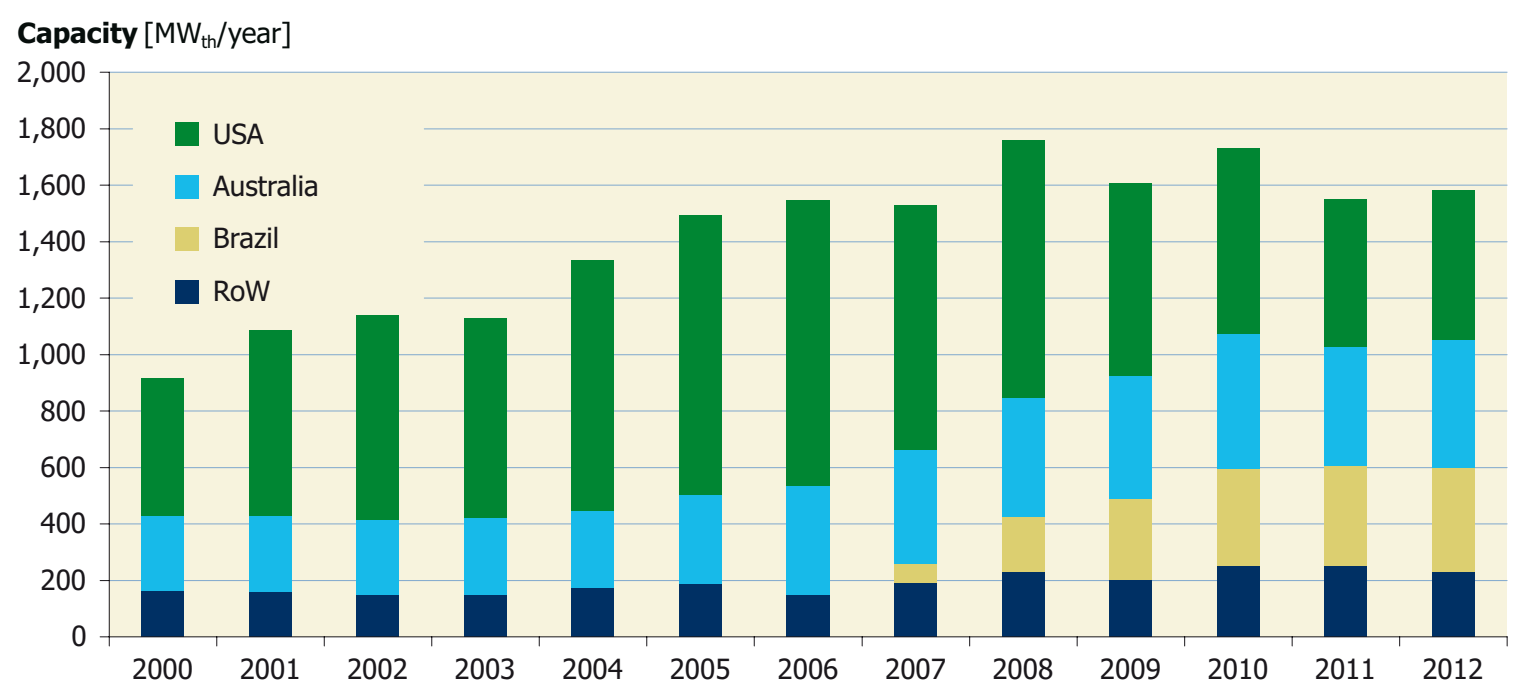

Figure 27: Global market development of unglazed water collectors from 2000 to 2012

Although the unglazed water collector market in the United States faced a heavy market downturn between 2006 and 2011, the global annual market volume for unglazed water collectors remained at a constant level between $1.5 \mathrm{GW}_{\text {th }}$ and $1.75 \mathrm{GW}_{\text {th }}$ (Figure 27). The reason for this development is the Brazilian market, which entered in 2007 and has grown steeply since then (Figure 28).

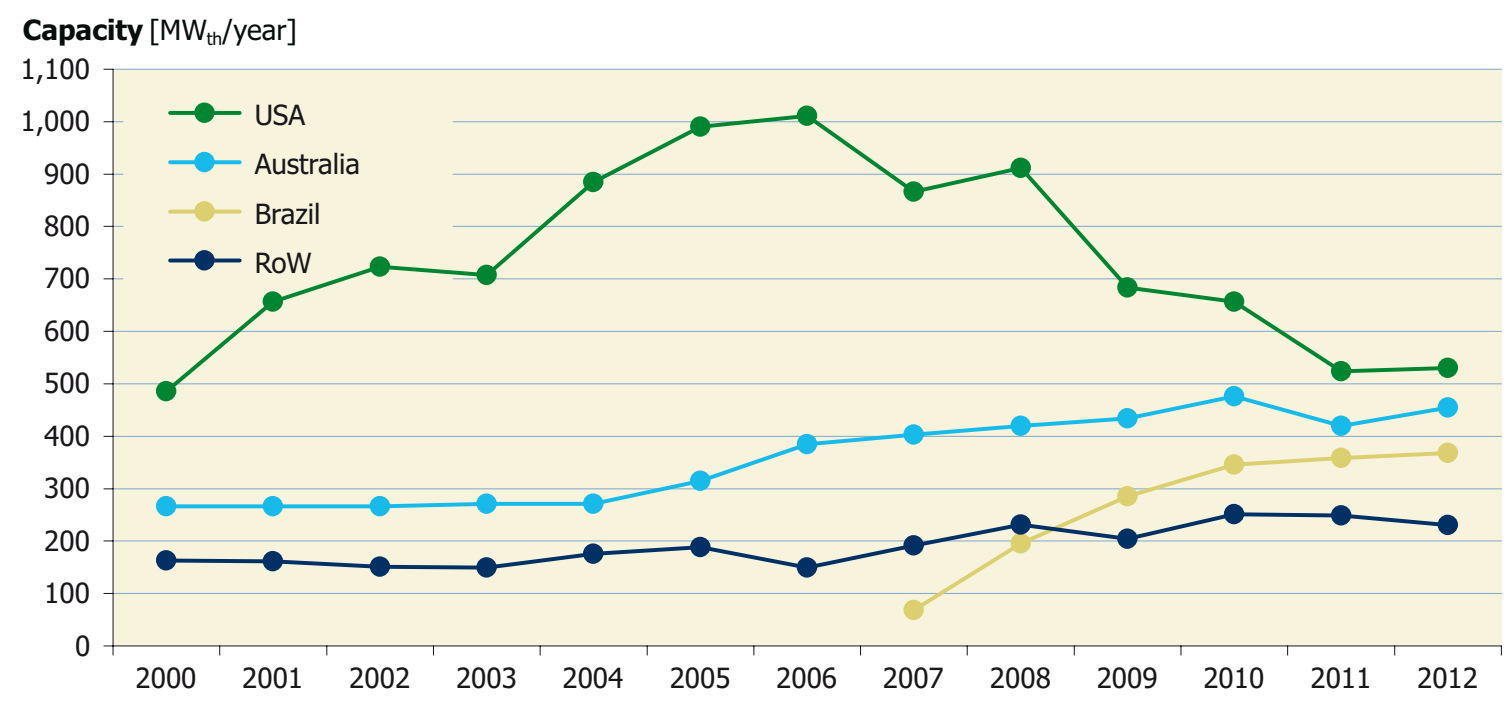

Figure 28: Global market development of unglazed water collectors from 2000 to 2012 


\section{Contribution to the energy supply and $\mathrm{CO}_{2}$ reduction}

In this section, the contribution of the total installed glazed and unglazed water collectors in operation to the thermal energy supply and $\mathrm{CO}_{2}$ reduction is shown.

The basis for these calculations is the total glazed and unglazed water collector area in operation in each country as shown in Table 1. The contribution of the total installed air collector capacity in operation in 2012 of $1.6 \mathrm{GW}_{\text {th }}$ was not taken into consideration - with a share of around $0.6 \%$ of the total installed collector capacity these collectors were omitted from the calculation.

The results are based on calculations using the simulation tool T-SOL expert 4.5 (www.valentin.de) for each country. For the simulations, different types of collectors and applications as well as the characteristic climatic conditions were considered for each country. A more detailed description of the methodology can be found in the appendix (see Chapter 8.1).

The annual collector yield of all water-based solar thermal systems in operation by the end of 2012 in the 58 recorded countries was 227.8 TWh (= $820 \mathrm{PJ})$. This corresponds to an energy savings equivalent of 24.5 million tons of oil and 79.1 million tons of $\mathrm{CO}_{2}$. The calculated number of different types of solar thermal systems in operation was around 78 million (Table 5).

The most important field of application for solar thermal systems is heating domestic hot water (see section 6.3), and therefore, this type of application also accounted for the highest savings in terms of oil equivalent and $\mathrm{CO}_{2}$. In $2012,92 \%$ of the energy provided by solar thermal systems worldwide was used for heating domestic hot water, mainly by small-scale systems in single family houses and larger applications attached to multi-family houses, hotels, schools, etc. Swimming pool heating held a share of $10 \%$ in the contribution to the energy supply and $\mathrm{CO}_{2}$ reduction and the remaining $2 \%$ was met by solar combi systems.

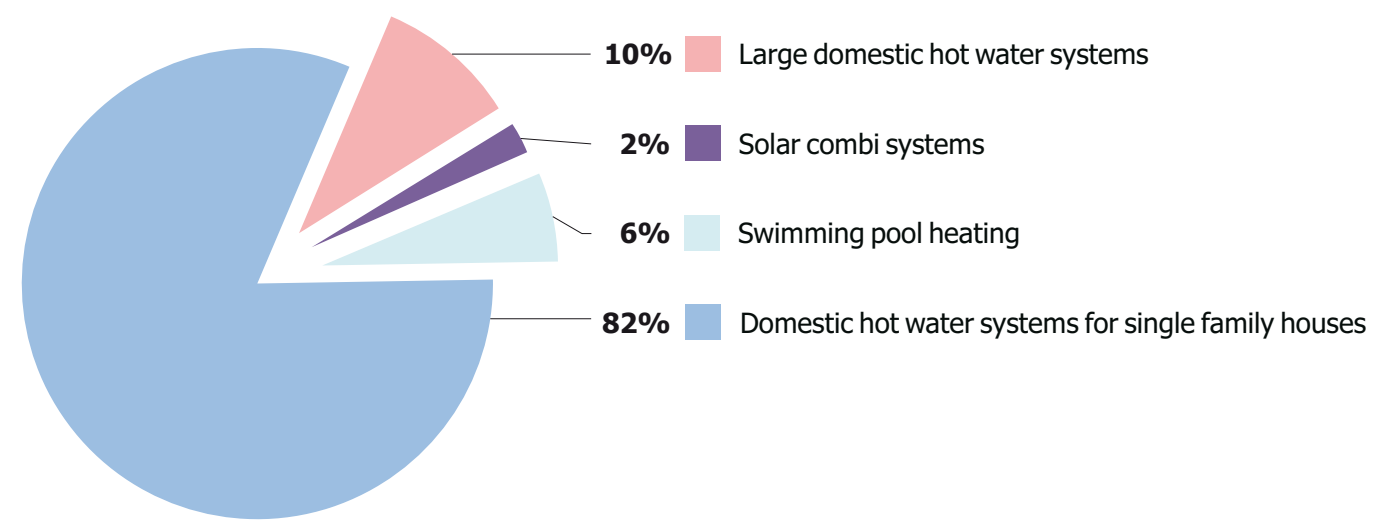

Figure 29: Share of energy savings and $\mathrm{CO}_{2}$ reduction

by type of application of glazed and unglazed water collectors in operation by the end of 2012

Table 5 summarizes the calculated annual collector yields and the corresponding oil equivalents and $\mathrm{CO}_{2}$ reductions of all water-based solar thermal systems (systems for hot water, space heating and swimming pool heating) in operation by the end of 2012 . 


\begin{tabular}{|c|c|c|c|c|c|c|}
\hline Country & $\begin{array}{c}\text { Total } \\
\text { collector area } \\
{\left[\mathbf{m}^{2}\right]}\end{array}$ & $\begin{array}{l}\text { Total } \\
\text { capacity } \\
{\left[\mathrm{MW}_{\text {th }}\right]}\end{array}$ & $\begin{array}{l}\text { Calculated } \\
\text { number } \\
\text { of systems }\end{array}$ & $\begin{array}{c}\text { Collector yield } \\
\text { [GWh/a] }\end{array}$ & $\begin{array}{c}\text { Energy savings } \\
{\left[\mathrm{t}_{\mathrm{oe}} / \mathrm{a}\right]}\end{array}$ & $\begin{array}{c}\mathrm{CO}_{2} \text { reduction } \\
{\left[\mathrm{t}_{\mathrm{CO} 2} / \mathrm{a}\right]}\end{array}$ \\
\hline Albania & 111,921 & 78 & 14,347 & 78 & 8,412 & 27,193 \\
\hline Australia & $7,326,000$ & 5,128 & $1,010,588$ & 4,598 & 494,147 & $1,597,429$ \\
\hline Austria & $4,927,748$ & 3,449 & 490,570 & 2,094 & 225,104 & 727,693 \\
\hline Barbados & 131,690 & 92 & 32,923 & 116 & 12,491 & 40,379 \\
\hline Belgium & 429,533 & 301 & 107,383 & 182 & 19,544 & 63,180 \\
\hline Brazil & $8,262,056$ & 5,783 & $1,329,864$ & 5,785 & 621,816 & $2,010,145$ \\
\hline Bulgaria & 122,100 & 85 & 22,455 & 64 & 6,841 & 22,116 \\
\hline Canada & 875,272 & 613 & 14,333 & 457 & 49,120 & 158,790 \\
\hline Chile & 80,009 & 56 & 10,065 & 60 & 6,451 & 20,854 \\
\hline China & $257,700,000$ & 180,390 & $58,742,715$ & 149,837 & $16,104,526$ & $52,061,101$ \\
\hline Croatia & 120,000 & 84 & 30,000 & 65 & 6,949 & 22,465 \\
\hline Cyprus & 890,511 & 623 & 196,236 & 791 & 85,064 & 274,987 \\
\hline Czech Republic & 891,738 & 624 & 60,205 & 382 & 41,074 & 132,780 \\
\hline Denmark & 663,409 & 464 & 77,712 & 286 & 30,766 & 99,457 \\
\hline Estonia & 6,520 & 5 & 1,630 & 3 & 303 & 978 \\
\hline Finland & 48,502 & 34 & 12,126 & 21 & 2,298 & 7,430 \\
\hline France (mainland) & $2,466,801$ & 1,727 & 387,400 & 1,194 & 128,321 & 414,824 \\
\hline Germany & $16,839,600$ & 11,788 & $1,841,364$ & 6,939 & 745,807 & $2,410,971$ \\
\hline Greece & $4,122,000$ & 2,885 & $1,591,106$ & 3,164 & 340,057 & $1,099,302$ \\
\hline Hungary & 233,300 & 163 & 27,008 & 109 & 11,671 & 37,730 \\
\hline India & $6,451,000$ & 4,516 & $1,224,561$ & 5,423 & 582,826 & $1,884,103$ \\
\hline Ireland & 271,968 & 190 & 62,943 & 114 & 12,239 & 39,564 \\
\hline Israel & $4,176,817$ & 2,924 & $1,381,826$ & 3,910 & 420,271 & $1,358,610$ \\
\hline Italy & $3,446,766$ & 2,413 & 590,603 & 2,119 & 227,796 & 736,395 \\
\hline Japan & $4,461,560$ & 3,123 & $1,094,867$ & 2,610 & 280,508 & 906,799 \\
\hline Jordan & $1,124,034$ & 787 & 198,953 & 1,064 & 114,325 & 369,580 \\
\hline Korea, South & $1,684,824$ & 1,179 & 242,952 & 854 & 91,753 & 296,611 \\
\hline Latvia & 4,040 & 3 & 1,010 & 2 & 200 & 648 \\
\hline Lebanon & 526,000 & 368 & 113,353 & 448 & 48,185 & 155,766 \\
\hline Lithuania & 6,000 & 4 & 1,500 & 3 & 290 & 939 \\
\hline Luxembourg & 39,800 & 28 & 9,950 & 18 & 1,923 & 6,218 \\
\hline Macedonia & 25,744 & 18 & 3,298 & 15 & 1,661 & 5,370 \\
\hline Malta & 48,293 & 34 & 12,073 & 42 & 4,505 & 14,563 \\
\hline Mexico & $2,029,876$ & 1,421 & 105,300 & 1,244 & 133,710 & 432,246 \\
\hline Morocco & 491,261 & 344 & 122,815 & 439 & 47,209 & 152,611 \\
\hline Mozambique & 273 & 0.2 & 68 & 0.2 & 25 & 81 \\
\hline Namibia & 22,006 & 15 & 2,718 & 20 & 2,158 & 6,975 \\
\hline Netherlands & 864,642 & 605 & 130,026 & 385 & 41,402 & 133,839 \\
\hline New Zealand & 159,645 & 112 & 39,911 & 103 & 11,101 & 35,886 \\
\hline Norway & 36,126 & 25 & 1,308 & 14 & 1,479 & 4,780 \\
\hline Poland & $1,211,500$ & 848 & 152,447 & 495 & 53,173 & 171,893 \\
\hline Portugal & 969,805 & 679 & 188,330 & 753 & 80,932 & 261,629 \\
\hline Romania & 110,700 & 77 & 27,675 & 66 & 7,063 & 22,834 \\
\hline Russia & 18,898 & 13 & 743 & 8 & 847 & 2,737 \\
\hline Slovakia & 147,000 & 103 & 24,500 & 71 & 7,595 & 24,551 \\
\hline Slovenia & 186,800 & 131 & 28,250 & 78 & 8,353 & 27,003 \\
\hline South Africa & $1,363,512$ & 954 & 125,969 & 904 & 97,113 & 313,937 \\
\hline Spain & $2,962,824$ & 2,074 & 341,762 & 2,063 & 221,693 & 716,666 \\
\hline Sweden & 450,000 & 315 & 34,103 & 187 & 20,061 & 64,851 \\
\hline Switzerland & $1,265,490$ & 886 & 153,112 & 540 & 58,026 & 187,580 \\
\hline Taiwan & $1,434,183$ & 1,004 & 293,158 & 880 & 94,586 & 305,769 \\
\hline Thailand & 120,360 & 84 & 30,090 & 103 & 11,043 & 35,697 \\
\hline Tunisia & 639,218 & 447 & 223,551 & 575 & 61,751 & 199,622 \\
\hline Turkey & $15,497,913$ & 10,849 & $3,589,317$ & 13,904 & $1,494,448$ & $4,831,103$ \\
\hline United Kingdom & 709,673 & 497 & 177,418 & 295 & 31,674 & 102,391 \\
\hline United States & $23,209,601$ & 16,247 & 976,949 & 11,793 & $1,267,572$ & $4,097,679$ \\
\hline Uruguay & 12,571 & 9 & 3,143 & 9 & 921 & 2,977 \\
\hline Zimbabwe & 19,568 & 14 & 4,892 & 17 & 1,796 & 5,808 \\
\hline TOTAL & $382,449,002$ & 267,714 & $77,715,472$ & 227,790 & $24,482,975$ & $79,146,115$ \\
\hline
\end{tabular}

Table 5: Calculated annual collector yield and corresponding oil equivalent and $\mathrm{CO}_{2}$ reduction of glazed and unglazed water collectors in operation by the end of 2012

In Chapters 5.1 to 5.3, the annual collector yield, energy savings and $\mathrm{CO}_{2}$ savings by economic regions and worldwide are graphed. 


\subsection{Annual collector yield by economic region}

In 2012 gross solar thermal collector yields amounted to 227.8 TWh worldwide (Table 5) and the major share, $82 \%$, was contributed by domestic hot water applications for single family houses (Figure 29).

Of the thermal energy gains, China accounted for 66\% (150 TWh), Europe 16\% (37 TWh) and Rest of the World $18 \%$ (42 TWh) (Figure 30).

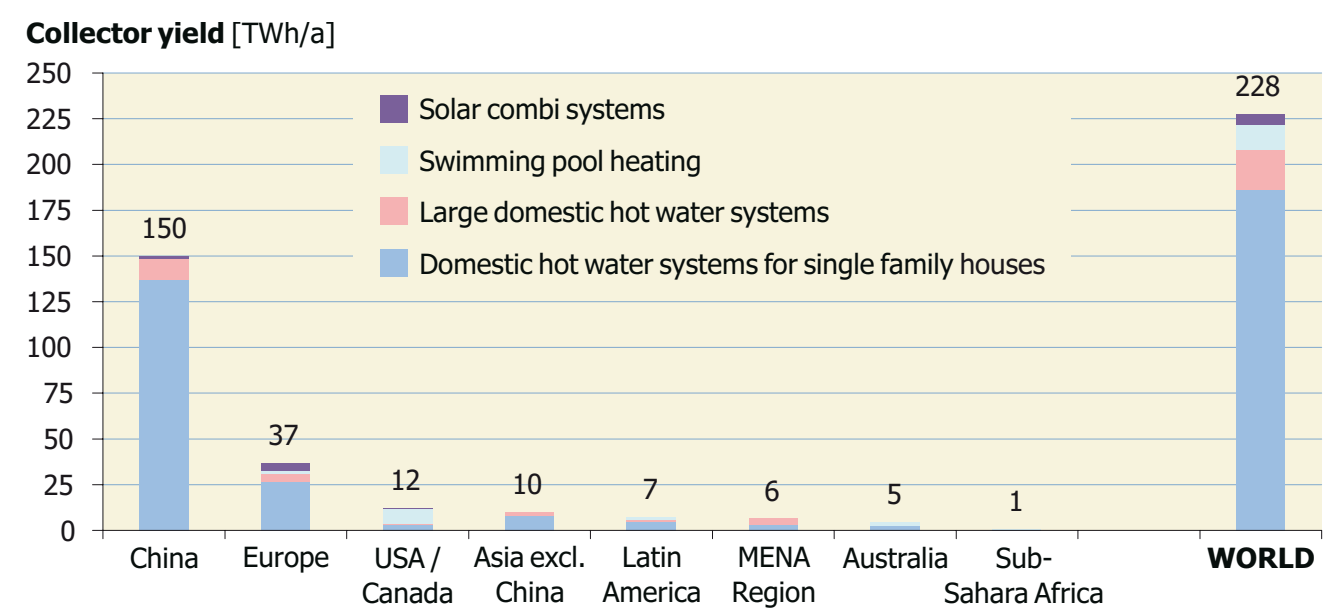

Figure 30: Annual collector yield of unglazed and glazed water collectors in operation by end of 2012

\subsection{Annual energy savings by economic region}

Considering a utilization ratio of 0.8 for the reference oil boiler, which is assumed to be partly replaced by the solar thermal system (see methodology Chapter 8.1), the annual final energy savings amounted to 284.7 TWh or 24.5 million tons of oil equivalent in $2012^{4}$.

The breakdown was China 16.1 million tons oil equivalent; Europe 16.1 million tons oil equivalent, Rest of World 4.5 million tons oil equivalent (Figure 31 ).

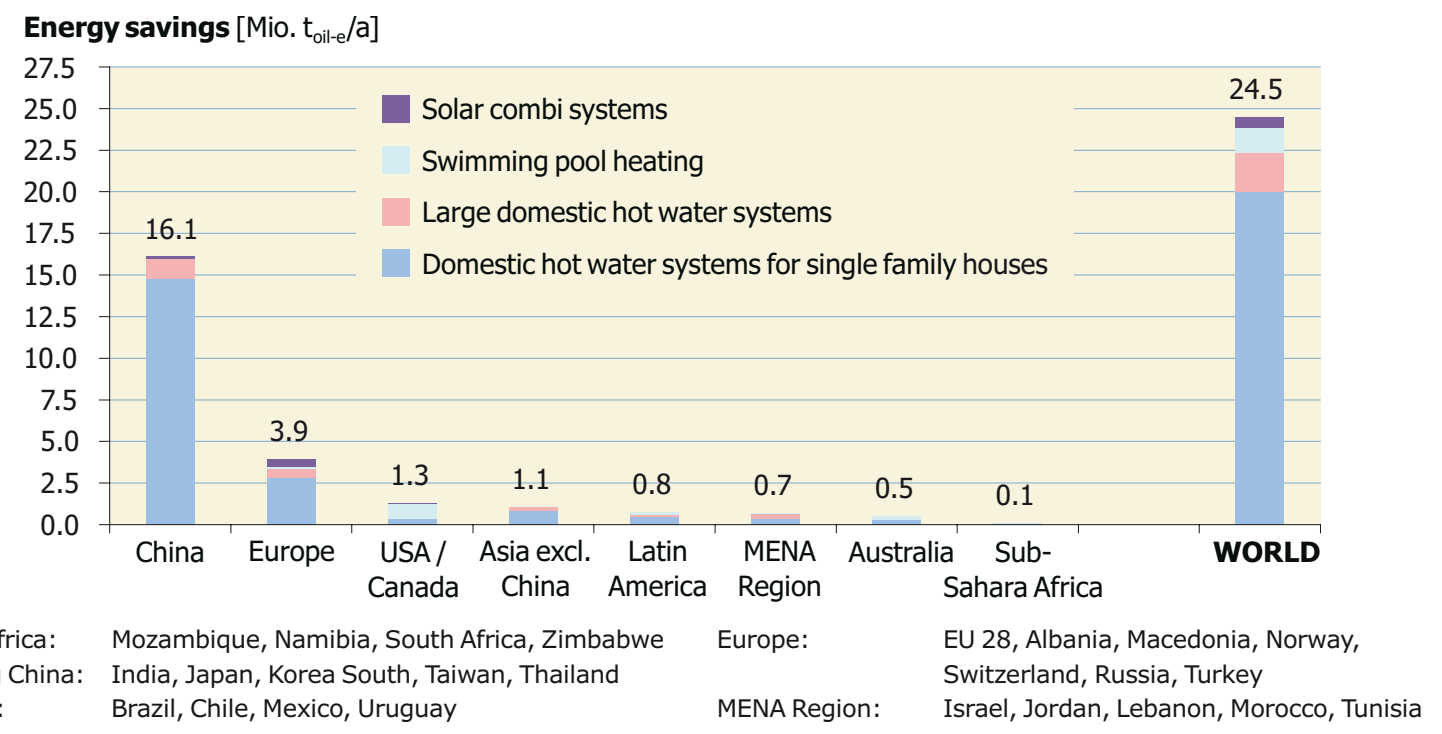

$\begin{array}{llll}\text { Sub-Sahara Africa: } & \text { Mozambique, Namibia, South Africa, Zimbabwe } & \text { Europe: } & \text { EU 28, Albania, Macedonia, Norway, } \\ \text { Asia excluding China: } & \text { India, Japan, Korea South, Taiwan, Thailand } & & \text { Switzerland, Russia, Turkey } \\ \text { Latin America: } & \text { Brazil, Chile, Mexico, Uruguay } & \text { MENA Region: } & \text { Israel, Jordan, Lebanon, Morocco, Tunisia }\end{array}$

Figure 31: Annual energy savings in oil equivalent by unglazed and glazed water collectors in operation by end of 2012 


\subsection{Annual contribution to $\mathrm{CO}_{2}$ reduction by economic region}

24.5 million tons of oil equivalents correspond to an annual $\mathrm{CO}_{2}$ emission reduction of 79.1 million tons ${ }^{5}$. Here, the breakdown was China 52.1 million tons of $\mathrm{CO}_{2} \mathrm{e}$; Europe 12.7 million tons of $\mathrm{CO}_{2} \mathrm{e}$, Rest of World 14.4 million tons of $\mathrm{CO}_{2} \mathrm{e}$ (see Figure 32 ).

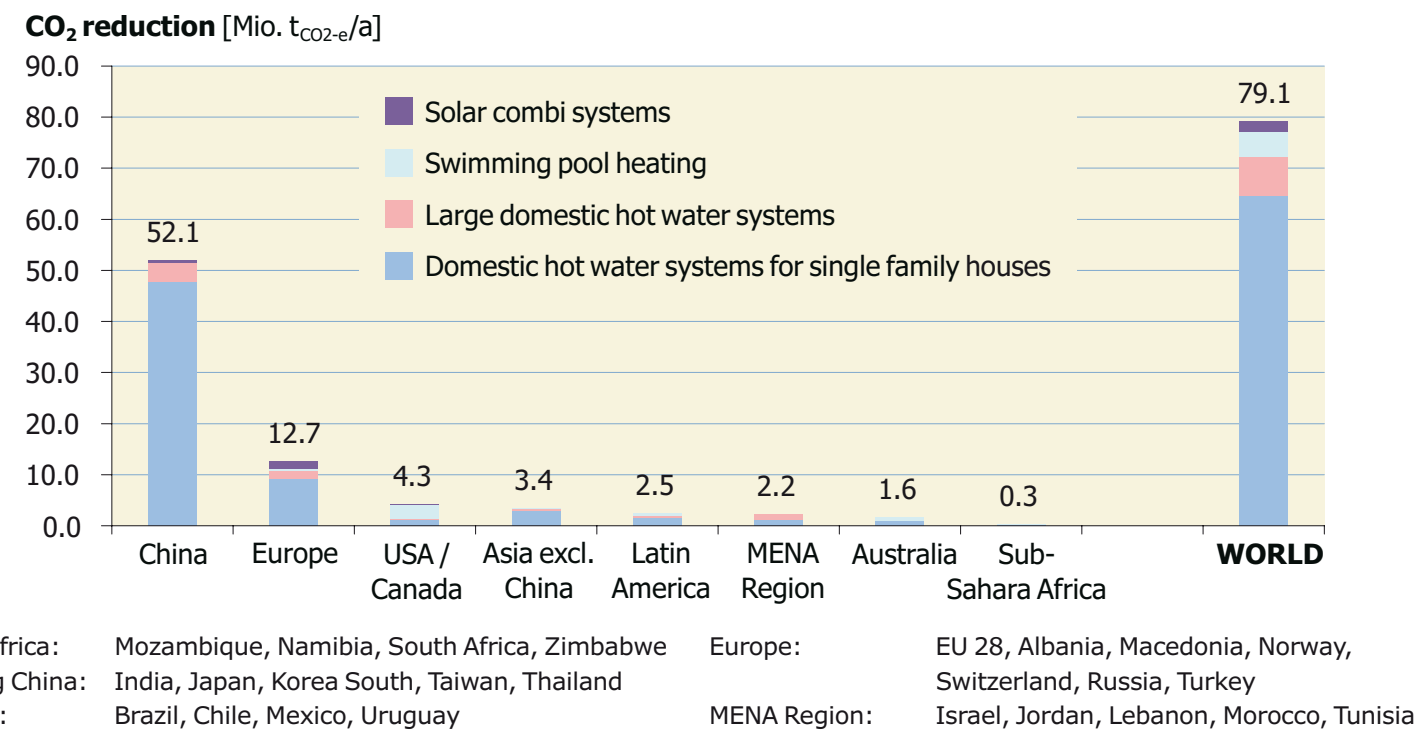

$\begin{array}{llll}\text { Sub-Sahara Africa: } & \text { Mozambique, Namibia, South Africa, Zimbabwe } & \text { Europe: } & \text { EU 28, Albania, Macedonia, Norway, } \\ \text { Asia excluding China: } & \text { India, Japan, Korea South, Taiwan, Thailand } & & \text { Switzerland, Russia, Turkey } \\ \text { Latin America: } & \text { Brazil, Chile, Mexico, Uruguay } & \text { MENA Region: } & \text { Israel, Jordan, Lebanon, Morocco, Tunisia }\end{array}$

Figure 32: Contribution to $\mathrm{CO}_{2}$ reduction by unglazed and glazed water collectors in operation by end of 2012 


\section{Distribution of systems by system type and application}

The use of solar thermal energy varies greatly from region to region and can be roughly distinguished by the type of solar thermal collector used (unglazed water collectors, evacuated tube collectors, flat plate collectors, glazed and unglazed air collectors, concentrating collectors), the type of system operation (pumped solar thermal systems, thermosiphon systems), and the main type of application (swimming pool heating, domestic hot water preparation, space heating, others such as heating of industrial processes, solar district heating or solar thermal cooling).

In Chapters 6.1 to 6.3, the share of these system types and applications are shown by different economic regions for both the cumulated capacity in operation by the end of 2012 and the newly installed capacity in $2012^{6}$.

\subsection{Distribution by type of solar thermal collector}

In terms of the total water collector area, evacuated tube collectors dominated with a share of $65 \%$ of the cumulated capacity in operation (Figure 33 ) and a share of $82 \%$ of the newly installed capacity (Figure 34). Especially in China, vacuum tube collectors played an important role and since this was by far the largest market supported by high growth rates, the worldwide figures tend towards a higher share of this type of solar thermal collector. Unglazed water collectors accounted for $8 \%$ of the cumulated water collectors installed worldwide and for $3 \%$ of the newly installed capacity.

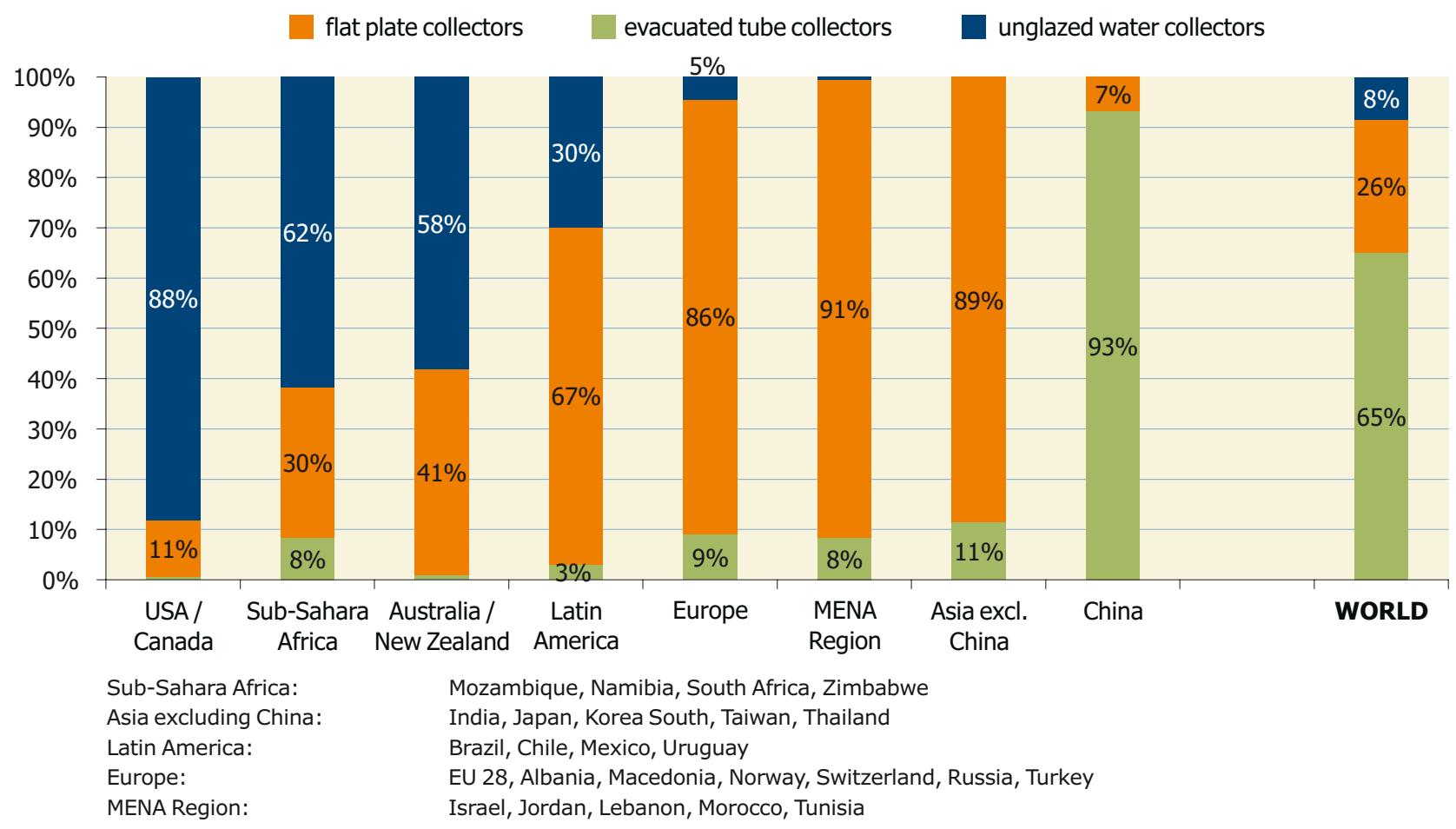

Figure 33: Distribution by type of solar thermal collector

for the total installed water collector capacity in operation by the end of 2012 


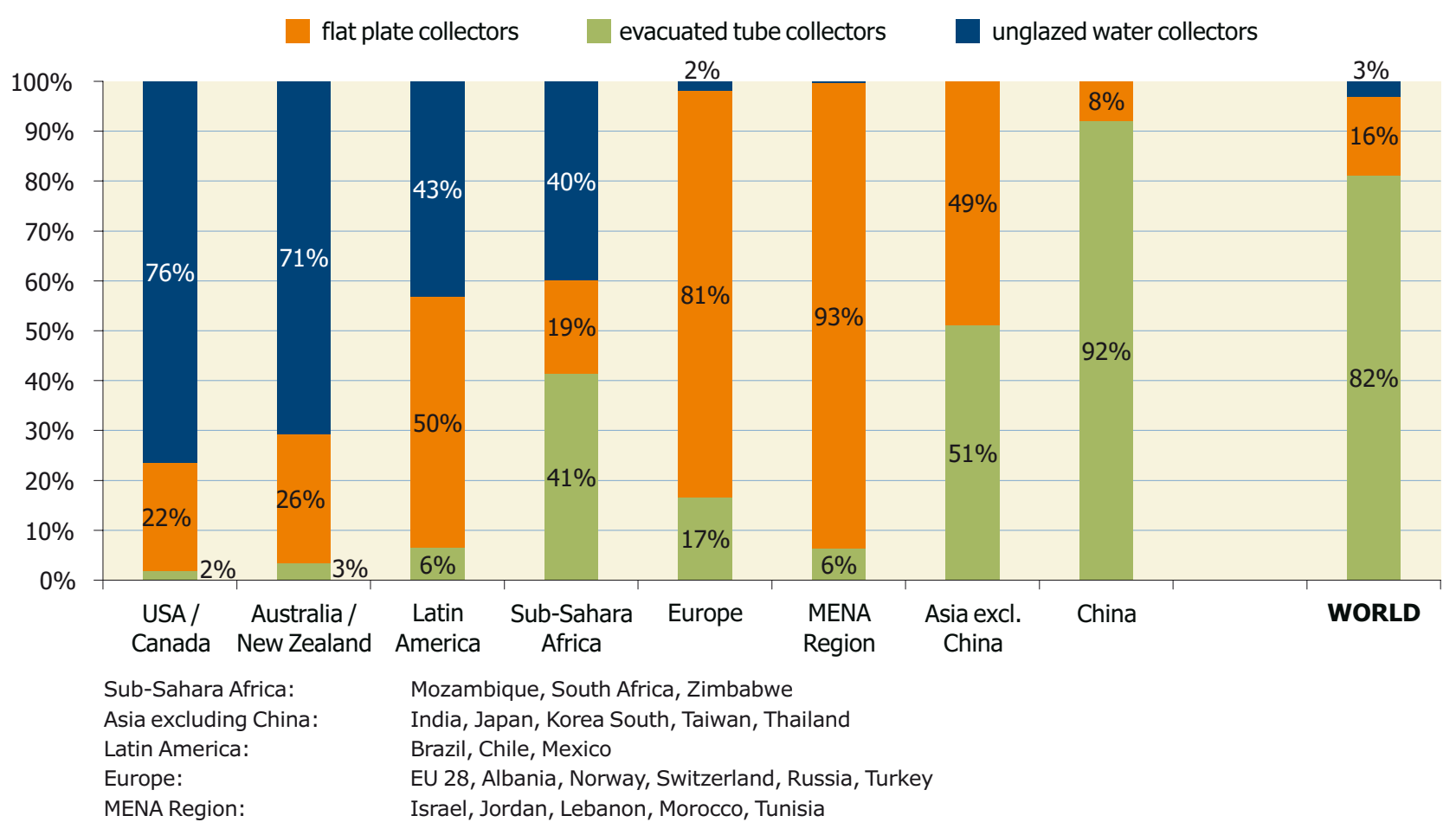

Figure 34: Distribution by type of solar thermal collector for the newly installed water collector capacity in 2012

\subsection{Distribution by type of system}

Worldwide, about three quarters of all solar thermal systems installed are thermosiphon systems and the rest are pumped solar heating systems (Figure 35). Similar to the distribution by type of solar thermal collector in total numbers the Chinese market influenced the overall figures most, and in 2012 89\% of the newly installed systems were estimated to be thermosiphon systems while pumped systems only accounted for $11 \%$ (Figure 36).

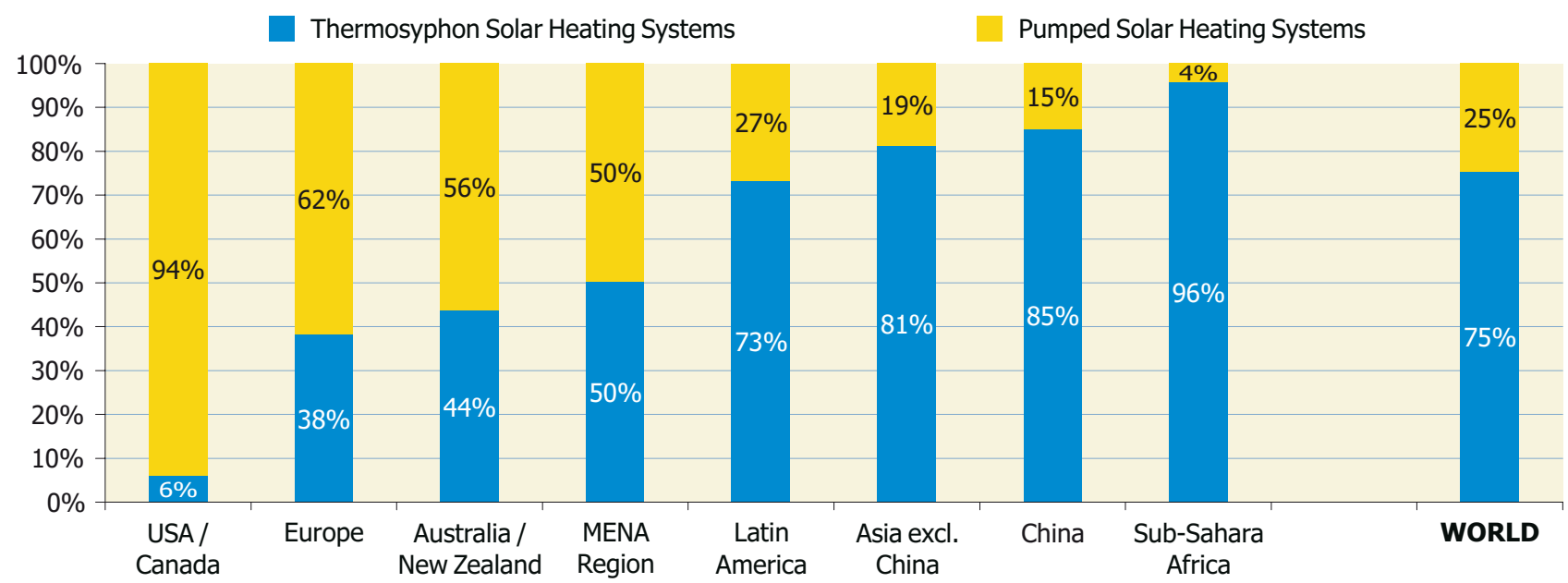

Sub-Sahara Africa: Namibia, South Africa Europe:

Asia excluding China: India, Japan, Korea South, Taiwan, Thailand MENA Region:

EU 27, Albania, Norway, Switzerland, Turkey Latin America: Brazil, Chile

Israel, Jordan, Lebanon, Tunisia

Figure 35: Distribution by type of system for the total installed glazed water collector capacity in operation by the end of 2012 


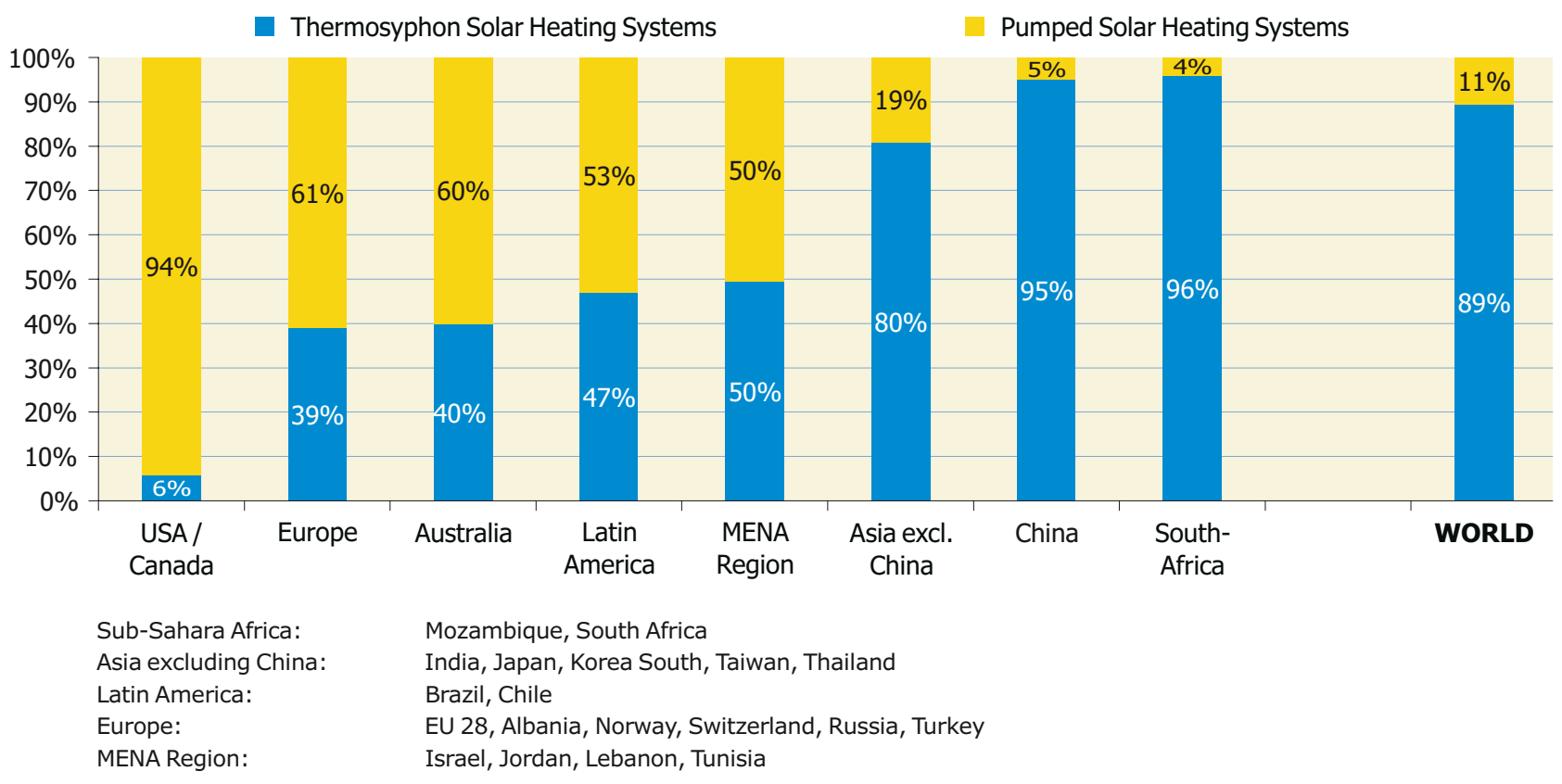

Figure 36: Distribution by type of system for the newly installed glazed water collector capacity in 2012

In general, thermosiphon systems are more common in warm climates such as in Africa, Latin America, southern Europe and the MENA region. In these regions thermosiphon systems are more often equipped with flat plate collectors, while in China, the typical thermosiphon system for domestic hot water preparation is equipped with evacuated tubes.

\subsection{Distribution by kind of application}

The calculated number of water-based solar thermal systems in operation by the end of 2012 was round 78 million (Table 5). Of these, $8 \%$ were used for swimming pool heating, $78 \%$ were used for domestic hot water preparation in single family houses and $9 \%$ were attached to larger domestic hot water systems for multifamily houses, hotels, hospitals, schools, etc. Around $4 \%$ of the worldwide installed capacity supplied heat for both domestic hot water and space heating (solar combi-systems). The remaining systems accounted for around $1 \%$ or almost 4 million square meters of solar thermal collectors and delivered heat to district heating networks, industrial processes or thermally driven solar cooling applications (Figure 37).

Compared to the cumulated installed capacity, the share of swimming pool heating was much less for new installations ( $8 \%$ of total capacity and only $2 \%$ of newly installed capacity). And to a lower extent this was also true for domestic hot water systems in single family houses. Here the share shows a declining trend, but with a share of $77 \%$ in 2012 this is still the most common application for solar thermal systems worldwide. The share of large-scale domestic hot water applications tended to increase ( $9 \%$ of total capacity and $17 \%$ of newly installed capacity) while the share of solar-combi systems remained at a low level of 3-4\% worldwide (Figure 38). 


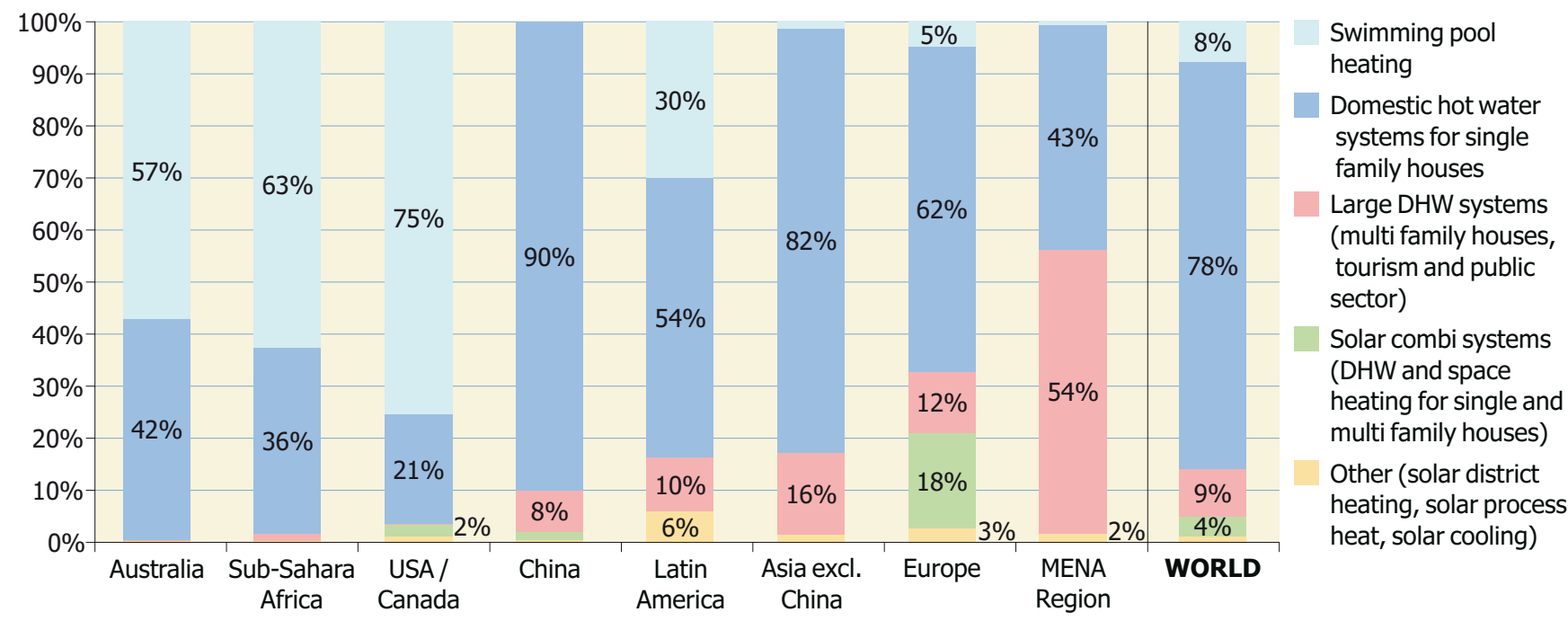

DHW Domestic hot water

Sub-Sahara Africa: Namibia, South Africa

Asia excluding China: India, Japan, Korea South, Taiwan,

Latin America:

Europe:

Brazil, Chile, Mexico

EU 18, Albania, Norway, Switzerland, Russia, Turkey

MENA Region:

Israel, Jordan, Lebanon, Tunisia

Figure 37: Distribution of solar thermal systems by application for the total installed water collector capacity by economic region in operation by the end of 2012

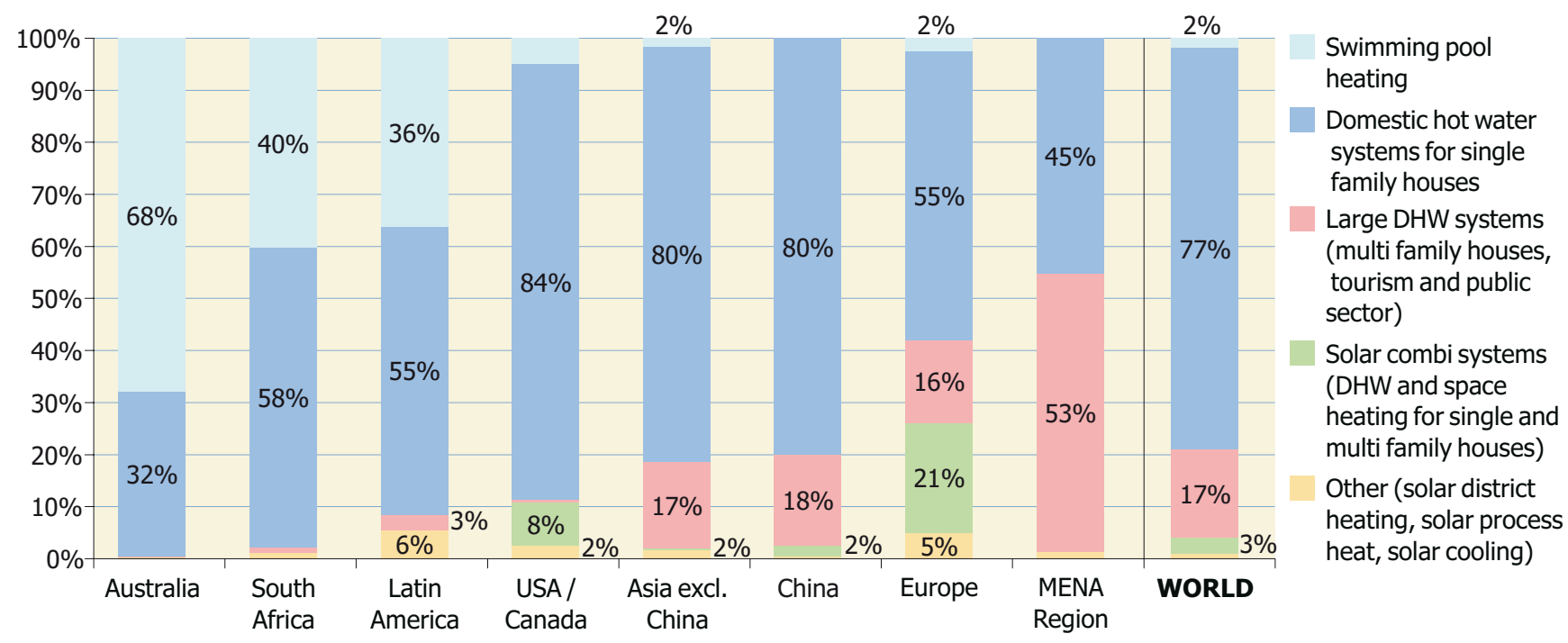

DHW Domestic hot water

Asia excluding China: India, Japan, Korea South, Taiwan, Thailand

Latin America: Brazil, Chile, Mexico

Europe: $\quad$ EU 18, Albania, Norway, Switzerland, Russia, Turkey

MENA Region: Israel, Jordan, Lebanon, Tunisia

Figure 38: Distribution of solar thermal systems by application for the newly installed water collector capacity by economic region in 2012 
Of the top 10 markets in terms of newly installed glazed water collector capacity, Germany, Italy, Poland, India, and Brazil have the most sophisticated markets for different solar thermal applications (Figure 39). The applications include domestic hot water preparation, space heating of single and multi-family houses, and hotels. In addition a noteworthy share of other applications include those for solar district heating, solar process heating and solar cooling.

It should be noted that some countries appear to "specialize" in certain applications. In Denmark, for example, more than two thirds of the 2012 newly installed capacity was large-scale solar thermal systems attached to district heating networks. The data shows that $40,000 \mathrm{~m}^{2}$ of solar assisted solar thermal systems were installed in Denmark in $2011,76,000 \mathrm{~m}^{2}$ in 2012, and another $96,000 \mathrm{~m}^{2}$ in 2013. By end of 2013 fifty large-scale solar district heating plants with an average system size of around 7,800 $\mathrm{m}^{2}$ were installed in Denmark (see Chapter 7.2). In India a notable share of concentrating solar thermal collectors are in use and the most commonly used are Scheffler dishes. They are used for community cooking in temples, prisons, student hostels, community places of stay, etc. Moreover, solar process heat installations with both concentrating and conventional non-concentrating collectors are increasing due to rising oil prices.

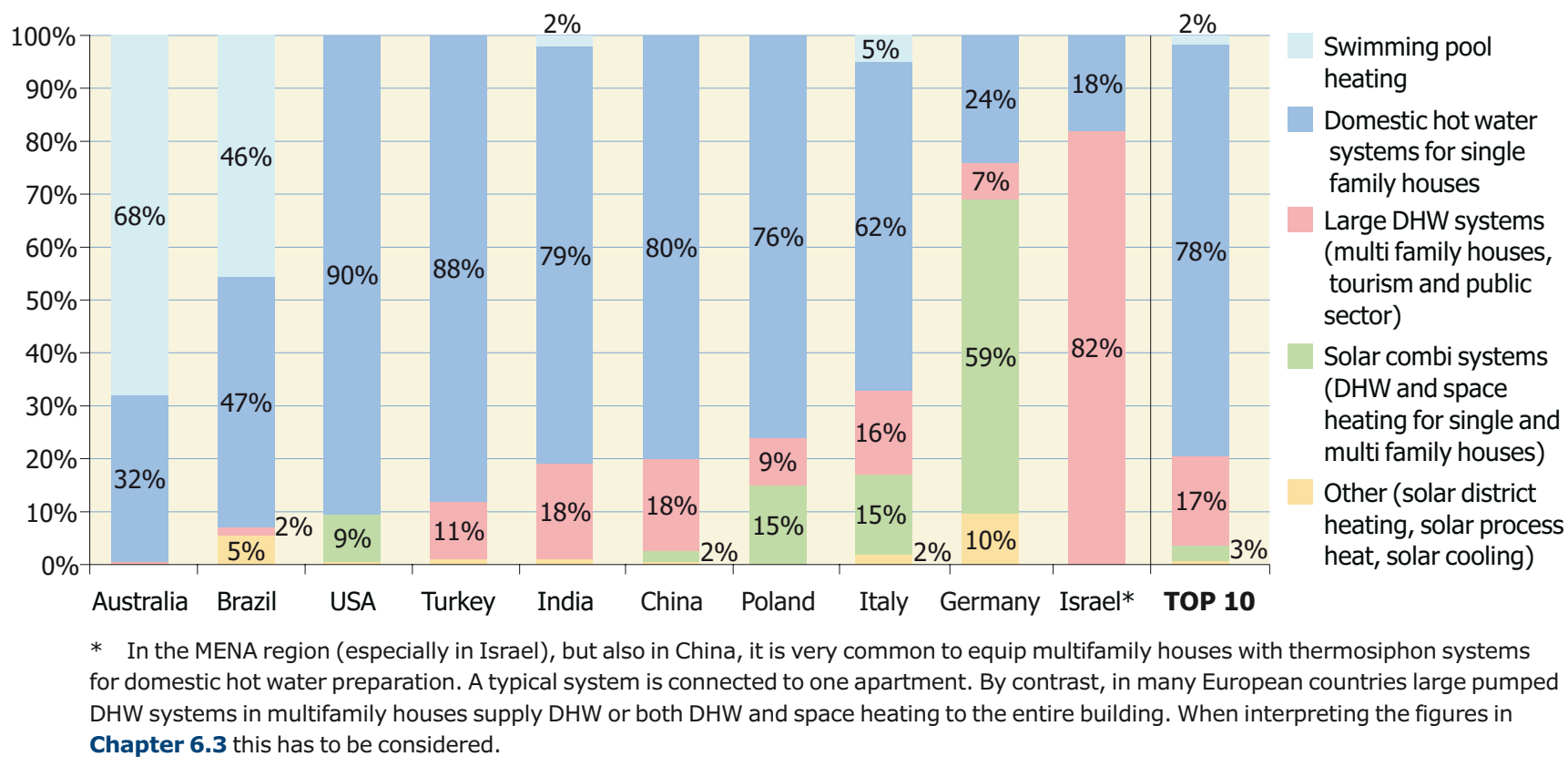

Figure 39: Distribution of solar thermal systems by application for the 10 leading markets of the newly installed glazed water collector capacity in 2011 


\section{Exceptional markets and applications for solar thermal systems}

\subsection{Overview of global megawatt-scale solar thermal applications}

Megawatt-scale solar supported district heating systems and solar heating and cooling applications in the commercial and industrial sector have gained increasing interest all over the world in recent years, and several ambitious projects have been successfully implemented.

In June 2013 the world's largest collector field was commissioned in Chile. The installation with a maximum thermal peak capacity of $32 \mathrm{MW}$ covers a total of $39,300 \mathrm{~m}^{2}$ of flat plate collector area connected to $4,000 \mathrm{~m}^{3}$ thermal energy storage. The projected thermal energy output is $51.8 \mathrm{GWh}$ per year. The solar thermal system is designed to cover $85 \%$ of the process heat demand needed to refine copper at the world's largest copper mine?.

The world's largest solar district heating plant started its operation in February 2014 in Dronninglund, Denmark. The collector field, with a collector area of $37,275 \mathrm{~m}^{2}\left(26 \mathrm{MW}_{\mathrm{th}}\right)$ together with a seasonal storage, is designed to cover around $50 \%$ of the total annual heat demand of 1,400 connected customers. The collector field works together with a $60,000 \mathrm{~m}^{3}$ pit heat storage, gas motors for combined heat and power production (CHP), an absorption heat pump, a biomass boiler and a back-up oil boiler. Due to the large storage the gas motors will always be able to produce electricity when the electricity price is high-even when there is no heat load (as the storage then can absorb the heat production $)^{8}$. A system similar to the one in Dronninglund is installed in the Danish city of Marstal ${ }^{9}$ and more so-called smart district heating plants with large-scale solar thermal systems and seasonal storages are scheduled to be built in Denmark.

In Riyadh, Saudi Arabia another large-scale solar district heating plant was commissioned in July 2011. The solar thermal plant with a total capacity of $25 \mathrm{MW}_{\text {th }}\left(36.305 \mathrm{~m}^{2}\right)$ is connected to a heating network for the supply of space heating and domestic hot water at a university campus ${ }^{10}$. Another successful solar supported heating network was implemented in Alberta, Canada. The Drake Landing community uses a $1.6 \mathrm{MW}_{\text {th }}\left(2.293 \mathrm{~m}^{2}\right)$ centralized solar thermal plant connected to a seasonal storage to supply more than $90 \%$ of the energy needed for space heating of 52 detached energy efficient homes ${ }^{11}$.

In Singapore, a large-scale solar thermal heating and cooling installation with a total capacity of $2.73 \mathrm{MW}_{\text {th }}$ $\left(3,900 \mathrm{~m}^{2}\right)$ started operation in 2011. The roof mounted solar thermal plant is connected to a $1.76 \mathrm{MW}_{\text {th }}$ absorption chiller and supplies hot water and cooling to about 2,500 students, who live and study at a newly created 76,000 $\mathrm{m}^{2}$ campus ${ }^{12}$.

Probably the largest solar thermal system in the United States is a solar process heat application that was dedicated in April 2012 in North Carolina. The $5.5 \mathrm{MW}_{\text {th }}\left(7,800 \mathrm{~m}^{2}\right)$ solar thermal system equipped with flat plate collectors supplies hot water to a turkey processing plant, lessening the use of propane gas ${ }^{13}$.

http://www.sunmark.com/

For further information go to http://task45.iea-shc.org/

http://sunstore4.eu/

http://solarthermalworld.org/content/saudi-arabia-worlds-biggest-solar-thermal-plant-operation

http://www.dlsc.ca/

http://www.solid.at/

http://solarthermalworld.org/content/usa-contractor-runs-7804-m2-collector-system-prestage-foods-factory 
The largest solar process heat applications installed in China are connected to dyeing and weaving mill factories. A system with a thermal peak capacity of $9.1 \mathrm{MW}_{\text {th }}\left(13,000 \mathrm{~m}^{2}\right)$ was constructed in the province of Zhejiang and two other projects of $10.5 \mathrm{MW}_{\text {th }}\left(15,000 \mathrm{~m}^{2}\right)$ have been commissioned in the neighboring province of Jiangsu.

More examples of solar process heat applications can be found at http://ship-plants.info/.

\subsection{Large-scale solar district heating and cooling applications in Europe}

In the Scandinavian countries of Denmark and Sweden, but also in Austria, Germany, Spain and Greece large-scale solar thermal applications connected to local or district heating grids have been in use since the early 1980s.

By the end of 2013, 192 large-scale solar thermal systems $>350 \mathrm{~kW}_{\text {th }}\left(500 \mathrm{~m}^{2}\right)$ connected to heating networks and 17 systems connected to cooling networks were in operation in Europe. The total installed capacity of these systems equaled $423 \mathrm{MW}_{\text {th }}$ (about $600,000 \mathrm{~m}^{2}$ ). The average system size was $2.0 \mathrm{MW}_{\text {th }}$ or 2,900 $\mathrm{m}^{2}$.

In summary, 37 systems larger than $3.5 \mathrm{MW}_{\text {th }}$ or 5,000 $\mathrm{m}^{2}$ were reported with most installations in Denmark (30) followed by Germany (2), Sweden (1), Austria (1), the Netherlands (1), France (1) and Norway (1).

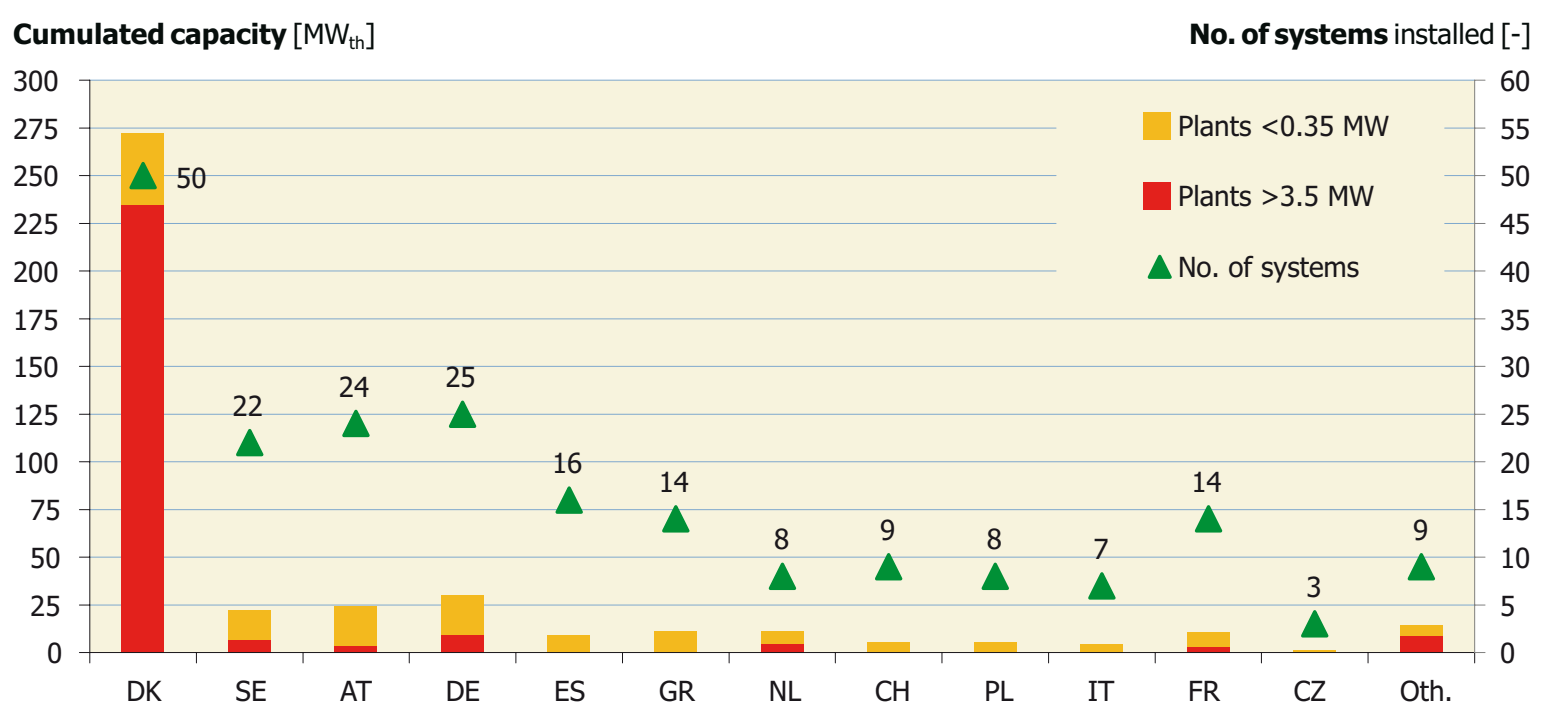

Figure 40: European large-scale solar heating systems by end of 2013

(Source: Jan-Olof Dalenbäck-Chalmers University of Technology)

By end of 2013, 9 of the 10 largest European solar thermal systems were installed in Denmark: Dronninglund $\left(37,275 \mathrm{~m}^{2}\right)$, Marstal $\left(33,300 \mathrm{~m}^{2}\right)$, Gråsten $\left(19,017 \mathrm{~m}^{2}\right)$, Braedstrup $\left(18,612 \mathrm{~m}^{2}\right)$, Tarm $\left(18,585 \mathrm{~m}^{2}\right)$, Vojens $\left(17,500 \mathrm{~m}^{2}\right)$, Ringkøbing $\left(15,000 \mathrm{~m}^{2}\right)$, Oksbøl $\left(14,745 \mathrm{~m}^{2}\right)$ and Jæegerspris $\left(13,300 \mathrm{~m}^{2}\right)$. The only system within the top 10 ranking outside of Denmark was commissioned in 2013 in Akershus, Norway (12,581 $\left.\mathrm{m}^{2}\right)$.

The market for solar supported district heating networks in Denmark has been booming for several years and is driven by high taxes for fossil fuels and an energy supply system that is characterized by decentralization on the one hand and a high share of wind energy for electricity production on the other hand. This together with the liberalized market mechanisms for electricity in Europe and low solar thermal system prices for large-scale systems make solar thermal heat in Denmark even competitive against natural gas driven combined heat and power systems in many cases $^{14}$. 


\subsection{Market for solar air conditioning and cooling applications}

Solar cooling applications convert the energy from the sun into cold by means of driving a thermal cooling machine with thermal energy generated with solar thermal collectors.

By the end of 2013, an estimated 1,050 solar cooling systems were installed worldwide. The marked showed a positive trend between 2004 and 2013, but the growth rates tended to decrease from 32\% in 2007/2008 to 11\% in 2012/ 2013.

Approximately $80 \%$ of the solar cooling installations worldwide are installed in Europe, most notably in Spain, Germany and Italy. The majority of these systems is equipped with flat plate or evacuated tube collectors. By contrast some examples for thermal cooling machines driven by concentrated solar thermal energy (with concentrating solar thermal collectors such as parabolic troughs or Fresnel collectors) were reported from India, Australia and Turkey ${ }^{15}$.

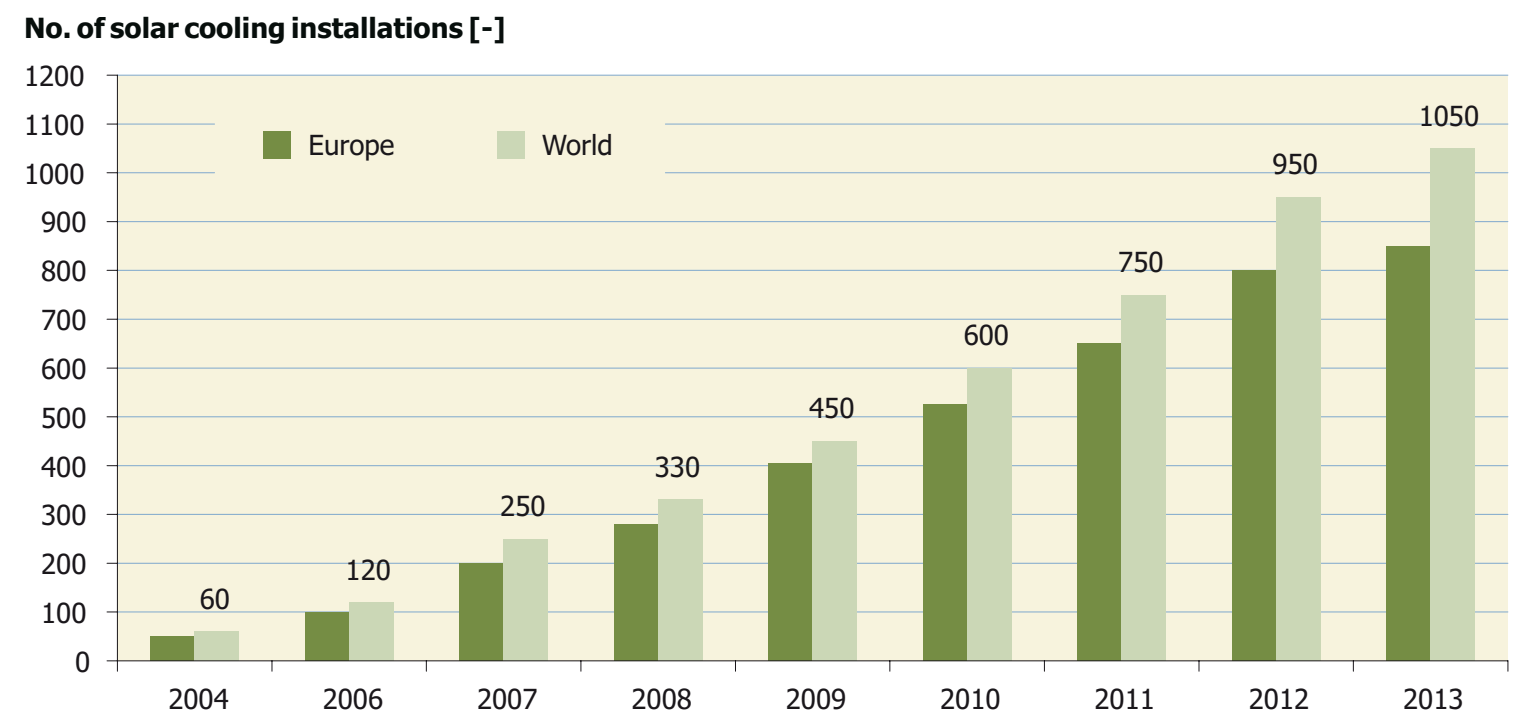

Figure 41: Market development 2004-2013 of small to large-scale solar air conditioning and cooling systems (Source: Climasol, EURAC, Fraunhofer ISE, Green Chiller, Rococo, Solem Consulting, Tecsol)

The overall number of systems installed to date indicates that solar cooling is still a niche market, but one which is developing. Since 2007 , a cost reduction of about $50 \%$ has been realized as a result of the further standardization of the solar cooling kits. 


\subsection{Good practice examples of world-wide installed solar process heat applications}

A variety of industrial processes demand vast amounts of thermal energy, which makes the industrial sector a promising market for solar thermal applications. Depending on the temperature level of the needed heat, different types of solar thermal collectors are used-air collectors, flat plate and evacuated tube collectors for temperatures at or below $100^{\circ} \mathrm{C}$ to concentrating solar thermal collectors such as parabolic troughs, Fresnel collectors or Scheffler dishes for temperatures up to $400^{\circ} \mathrm{C}$.

Currently Solar Heat for Industrial Processes (SHIP) is still a niche market, but a number of promising projects have been realized in the last couple of years ranging from small-scale demonstration plants to very large systems, such as the world's largest solar thermal plant in Chile, which delivers heat for the electro-winning of copper (see section 7).

Currently, 124 SHIP applications are reported to be in operation all over the world with a cumulated installed capacity of over $93 \mathrm{MW}_{\mathrm{th}}\left(133,200 \mathrm{~m}^{2}\right)$. Of that, 18 systems are larger than 1,000 $\mathrm{m}^{2}$ and another 25 systems are between $500-1,000 \mathrm{~m}^{2}$ (Figure 42).

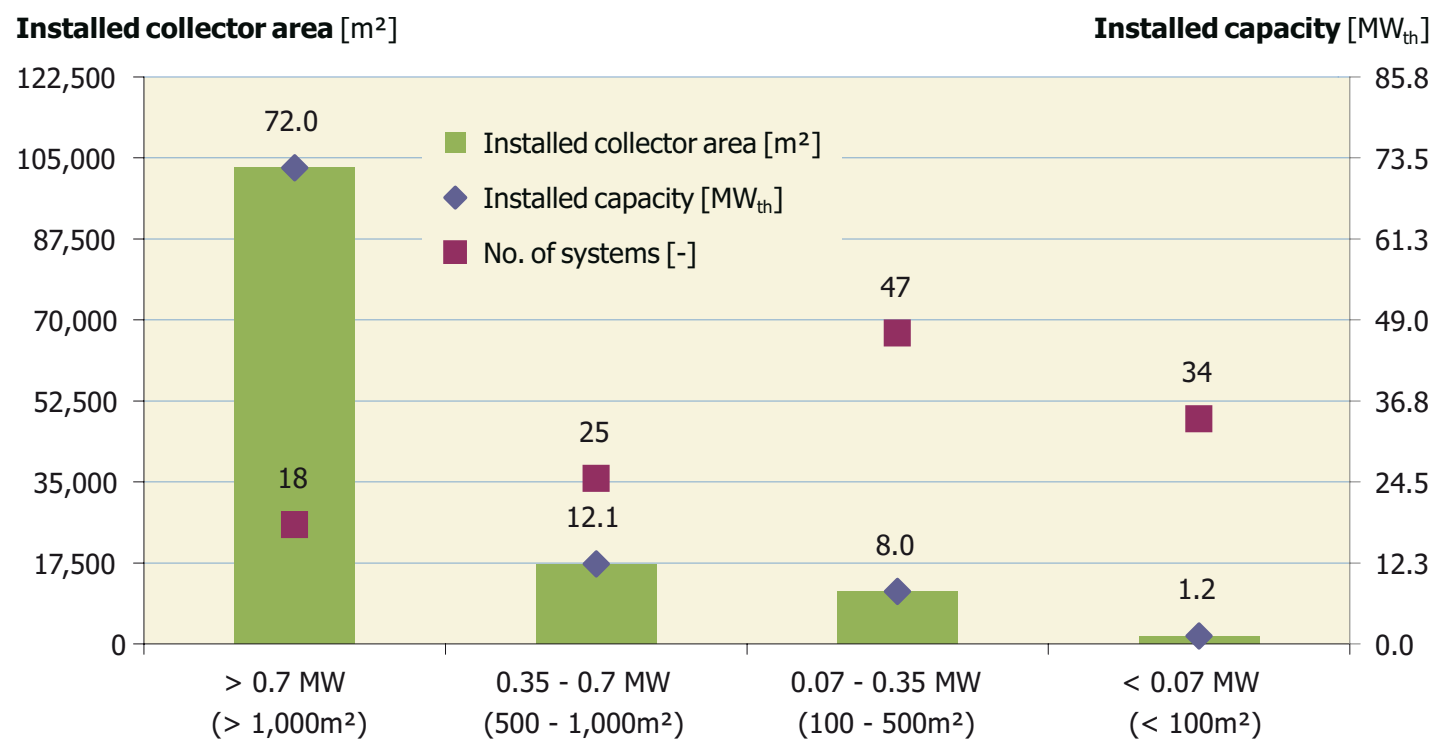

Figure 42: Global solar process heat applications in operation

(Source: IEA SHC Task49/IV SHIP database, accessed on 2014-05-16)

The SHIP database was created within the framework of IEA SHC Task 49/IV. This online database contains an overview of existing solar thermal plants worldwide. Each plant description contains detailed information, for example, location, size of the collector field, collector technology used, integration point in the production process and costs.

The SHIP database can be accessed by private users and it is the intention to continuously add new and existing SHIP applications in order to spread knowledge about the possibilities offered by this technology.

The database can be found at http://ship-plants.info/ 


\subsection{Market for Solar Air Heating Systems}

Solar air heating is a solar thermal technology in which the energy from the sun heats air. In colder climates, space heating is usually the largest use of building energy and it is the air in the buildings that is heated. Space heating consumes much more energy than hot water in most buildings. Solar air heating systems can be building integrated and typically reduce between $20-30 \%$ of conventional energy used for heating buildings.

The air is generally taken off the top of the wall (since hot air rises) and the heated or pre-heated fresh air is then connected to existing or new fans and ducted into the building via the ventilation system.

Solar air heaters are also common in agricultural applications primarily for drying.

Solar air heating systems have been used globally for the past 30 years by schools, municipalities, military, agricultural and commercial and industrial entities as well as in residential buildings. Wall mounted systems are common and take advantage of the lower winter sun angles and eliminate any snow accumulation typical of roof mounted systems. Storage of the heat is possible, but most solar air systems do not include storage to minimize costs.

Solar space heating with air collectors has not been common in Europe, likely due to the lack of an European test standard for air collectors, but in North America, building integrated solar air collectors are the most popular form of solar thermal systems in the commercial, industrial and institutional markets due to their low cost and architectural integration into buildings. 


\section{$8 \quad$ Appendix}

\subsection{Methodological approach for the energy calculation}

In order to obtain the energy yield of solar thermal systems, the oil equivalent saved and the $\mathrm{CO}_{2}$ emissions avoided, the following procedure was used:

- Only water collectors were used in the calculations (unglazed water collectors, flat-plate collectors and evacuated tube collectors). Air collectors were not included.

- For each country, the cumulated water collector area was allocated to the following applications (based on available country market data):

- Solar thermal systems for swimming pool heating

- Solar domestic hot water systems for single-family houses,

- Solar domestic hot water systems for multifamily houses including the tourism sector as well as the public sector (to simplify the analysis solar district heating systems, solar process heat and solar cooling applications were also allocated here), and

- Solar combi systems for domestic hot water and space heating for single- and multifamily houses.

- Reference systems were defined for each country and for each type of application (pumped or thermosiphon solar thermal system).

- The number of systems per country was determined from the share of collector area for each application and the collector area defined for the reference system.

Apart from the reference applications and systems mentioned above, reference collectors and reference climates were determined. On the basis of these boundary conditions, simulations were performed with the simulation program T-Sol [T-Sol, Version 4.5 Expert, Valentin Energiesoftware, www.valentin.de] and gross solar yields for each country and each system were obtained. The gross solar yields refer to the solar collector heat output and do not include heat losses through transmission piping or storage heat losses ${ }^{16}$.

The amount of final energy saved is calculated from the gross solar yields considering a utilization rate of the auxiliary heating system of 0.8 . Final energy savings are expressed in tons of oil equivalent (toe): 1 toe $=11,630 \mathrm{kWh}$.

Finally, the $\mathrm{CO}_{2}$ emissions avoided by the different solar thermal applications are quoted as kilograms carbon dioxide equivalent $\left(\mathrm{kgCO}_{2} \mathrm{e}\right)$ per tons of oil equivalent: 1 toe $=3.233 \mathrm{t} \mathrm{CO}_{2} \mathrm{e}^{17}$

To obtain an exact statement about the $\mathrm{CO}_{2}$ emissions avoided, the substituted energy medium would have to be ascertained for each country. Since this could only be done in a very detailed survey, which goes beyond the scope of this report, the energy savings and the $\mathrm{CO}_{2}$ emissions avoided therefore relate to fuel oil. It is obvious that not all solar thermal systems just replace systems running on oil. This represents a simplification since gas, coal, biomass or electricity can be used as the energy source for the auxiliary heating system instead of oil.

The following tables describe the key data of the reference systems in the different countries, the location of the reference climate used and the share of the total collector area in use for the respective application. Furthermore, a hydraulic scheme is shown for each reference system. considered were about 5 to $15 \%$ less depending on the system, the application and the climate. 


\subsubsection{Reference systems for swimming pool heating}

The information in Table 6 refers to the total capacity of water collectors in operation used for swimming pool heating as reported from each country by the end of 2012.

\begin{tabular}{|c|c|c|c|c|c|}
\hline Country* & Reference climate & $\begin{array}{l}\text { Total collector } \\
\text { area }\left[\mathrm{m}^{2}\right]\end{array}$ & $\begin{array}{c}\text { Collector area } \\
\text { per system [ }{ }^{2} \text { ] }\end{array}$ & $\begin{array}{c}\text { Total number of } \\
\text { systems }\end{array}$ & $\begin{array}{c}\text { Specific solar yield } \\
{\left[\mathrm{kWh} / \mathrm{m}^{2} \mathrm{a}\right]}\end{array}$ \\
\hline Australia & Sydney & $4,185,763$ & 34 & 123,111 & 466 \\
\hline Austria & Graz & 558,601 & 200 & 2,793 & 283 \\
\hline Brazil & Brasília & $2,271,569$ & 200 & 11,358 & 375 \\
\hline Canada & Montreal & 545,294 & 200 & 2,726 & 386 \\
\hline Cyprus & Nicosia & 2,147 & 200 & 11 & 508 \\
\hline Czech Republic & Prague & 526,194 & 200 & 2,631 & 303 \\
\hline Denmark & Copenhagen & 20,515 & 200 & 103 & 295 \\
\hline France & Paris & 23,583 & 200 & 118 & 328 \\
\hline Germany & Wurzburg & 585,600 & 200 & 2,928 & 314 \\
\hline Hungary & Budapest & 27,996 & 200 & 140 & 344 \\
\hline India & New-Delhi & 161,275 & 200 & 806 & 529 \\
\hline Israel & Jerusalem & 31,817 & 200 & 159 & 568 \\
\hline Italy & Bologna & 172,338 & 200 & 862 & 442 \\
\hline Jordan & Amman & 5,940 & 200 & 30 & 578 \\
\hline Mexico & Mexico City & 831,508 & 200 & 4,158 & 311 \\
\hline Netherlands & Amsterdam & 418,783 & 200 & 2,094 & 272 \\
\hline Norway & Oslo & 1,873 & 200 & 9 & 316 \\
\hline Portugal & Lisbon & 1,940 & 200 & 10 & 421 \\
\hline Russia & Moscow & 16 & 200 & 0 & 269 \\
\hline South Africa & Johannesburg & 867,194 & 200 & 4,336 & 505 \\
\hline Spain & Madrid & 148,141 & 200 & 741 & 472 \\
\hline Sweden & Gothenburg & 130,050 & 200 & 650 & 295 \\
\hline Switzerland & Zürich & 211,540 & 200 & 1,058 & 277 \\
\hline Taiwan & Taipei & 10,039 & 200 & 50 & 319 \\
\hline \multirow[t]{3}{*}{ United States } & LA, Indianapolis & $17,594,787$ & 200 & 87,974 & 387 \\
\hline & TOTAL & $29,334,505$ & & 248,854 & \\
\hline & AVERAGE & & 193 & & 382 \\
\hline
\end{tabular}

* Countries not listed in this table did not report any share of collectors used for swimming pool heating.

Table 6: Solar thermal systems for swimming pool heating by end of 2012

Figure $\mathbf{4 3}$ shows the hydraulic scheme of the swimming pool reference system as used for the simulations of the solar energy yields.

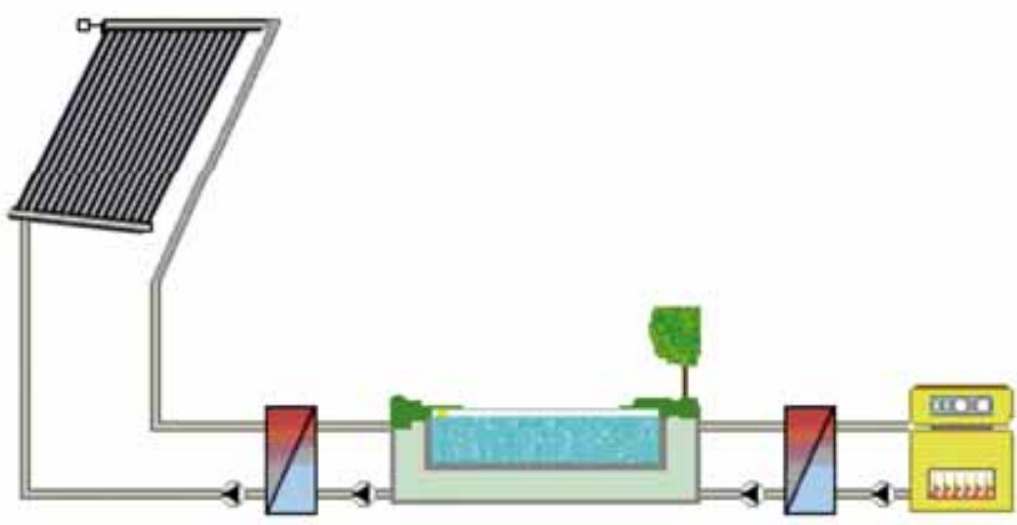

Figure 43: Hydraulic scheme of the swimming pool reference system 


\subsubsection{Reference systems for domestic hot water preparation in single-family houses}

The information in Table 7 refers to the total capacity of water collectors in operation used for domestic hot water heating in single family houses at the end of 2012 as reported by each country.

\begin{tabular}{|c|c|c|c|c|c|c|}
\hline Country & $\begin{array}{c}\text { Reference } \\
\text { climate }\end{array}$ & $\begin{array}{l}\text { Total collector } \\
\text { area }\left[\mathrm{m}^{2}\right]\end{array}$ & $\begin{array}{c}\text { Collector area } \\
\left.\text { per system [ } \mathbf{m}^{2}\right]\end{array}$ & $\begin{array}{c}\text { Total number of } \\
\text { systems }\end{array}$ & $\begin{array}{c}\text { Specific solar } \\
\text { yield [kWh/m² a] }\end{array}$ & $\begin{array}{l}\text { Type of } \\
\text { system }\end{array}$ \\
\hline Albania & Tirana & 31,864 & 2.5 & 12,746 & 713 & TS \\
\hline Australia & Sydney & $3,103,607$ & 3.5 & 886,745 & 844 & PS \\
\hline Austria & Graz & $2,051,412$ & 6.0 & 341,902 & 451 & PS \\
\hline Barbados & Grantley Adams & 131,690 & 4.0 & 32,923 & 882 & TS \\
\hline Belgium & Brussels & 429,533 & 4.0 & 107,383 & 423 & PDS / PS \\
\hline Brazil & Brasília & $5,211,723$ & 4.0 & $1,302,931$ & 809 & TS \\
\hline Bulgaria & Sofia & 87,014 & 4.0 & 21,753 & 524 & PS \\
\hline Canada & Montreal & 34,136 & 6.0 & 5,689 & 556 & PS \\
\hline Chile & Santiago de Chile & 36,804 & 4.0 & 9,201 & 771 & PS \\
\hline China & Shanghai & $231,930,000$ & 4.0 & $57,982,500$ & 592 & TS \\
\hline Croatia & Zagreb & 120,000 & 4.0 & 30,000 & 539 & PS \\
\hline Cyprus & Nicosia & 771,988 & 4.0 & 192,997 & 912 & TS \\
\hline Czech Republic & Prague & 179,752 & 4.7 & 38,245 & 385 & PS \\
\hline Denmark & Copenhagen & 279,756 & 4.0 & 69,939 & 454 & PS \\
\hline Estonia & Tallinn & 6,520 & 4.0 & 1,630 & 432 & PS \\
\hline Finland & Helsinki & 48,502 & 4.0 & 12,126 & 441 & PS \\
\hline France & Paris & 943,337 & 3.2 & 294,793 & 496 & PS \\
\hline Germany & Wurzburg & $7,314,300$ & 6.0 & $1,219,050$ & 424 & PS \\
\hline Greece & Athens & $3,969,486$ & 2.5 & $1,587,794$ & 772 & TS \\
\hline Hungary & Budapest & 139,980 & 6.0 & 23,330 & 473 & PS \\
\hline India & New-Delhi & $4,773,740$ & 4.0 & $1,193,435$ & 882 & TS \\
\hline Ireland & Dublin & 244,772 & 4.0 & 61,193 & 423 & PS \\
\hline Israel & Jerusalem & 829,000 & 3.0 & 276,333 & 1,024 & TS \\
\hline Italy & Bologna & $2,136,995$ & 4.0 & 534,249 & 661 & PS \\
\hline Japan & Tokyo & $4,372,329$ & 4.0 & $1,093,082$ & 586 & TS \\
\hline Jordan & Amman & 894,475 & 4.6 & 194,451 & 986 & TS \\
\hline Korea, South & Seoul & 909,805 & 4.0 & 227,451 & 525 & PS \\
\hline Latvia & Riga & 4,040 & 4.0 & 1,010 & 462 & PS \\
\hline Lebanon & Beirut & 447,100 & 4.0 & 111,775 & 860 & TS \\
\hline Lithuania & Vilnius & 6,000 & 4.0 & 1,500 & 450 & PS \\
\hline Luxembourg & Luxembourg & 39,800 & 4.0 & 9,950 & 450 & PS \\
\hline Macedonia & Skopje & 12,100 & 4.0 & 3,025 & 627 & PS \\
\hline Malta & Luqa & 48,293 & 4.0 & 12,073 & 868 & PS \\
\hline Mexico & Mexico City & 335,543 & 4.0 & 83,886 & 718 & PS \\
\hline Morocco & Rabat & 491,261 & 4.0 & 122,815 & 894 & TS \\
\hline Namibia & Windhoek & 9,903 & 4.0 & 2,476 & 1,032 & TS \\
\hline Netherlands & Amsterdam & 343,311 & 2.8 & 122,611 & 433 & PDS / PS \\
\hline New Zealand & Wellington & 159,645 & 4.0 & 39,911 & 647 & PS \\
\hline Norway & Oslo & 1,181 & 8.0 & 148 & 430 & PS \\
\hline Poland & Warsaw & 848,050 & 6.0 & 141,342 & 397 & PS \\
\hline Portugal & Lisbon & 725,414 & 4.0 & 181,354 & 804 & PS \\
\hline Romania & Bucharest & 110,700 & 4.0 & 27,675 & 594 & PS \\
\hline Russia & Moscow & 1,497 & 4.0 & 374 & 443 & PS \\
\hline Slovakia & Bratislava & 147,000 & 6.0 & 24,500 & 481 & PS \\
\hline Slovenia & Ljubljana & 155,044 & 6.0 & 25,841 & 424 & PS \\
\hline South Africa & Johannesburg & 485,683 & 4.0 & 121,421 & 1,009 & TS \\
\hline Spain & Madrid & $1,155,501$ & 4.0 & 288,875 & 766 & PS \\
\hline Sweden & Gothenburg & 34,200 & 4.0 & 8,550 & 383 & PS \\
\hline Switzerland & Zürich & 706,147 & 5.7 & 123,885 & 426 & PS \\
\hline Taiwan & Taipei & $1,404,065$ & 4.8 & 292,514 & 616 & TS \\
\hline Thailand & Bangkok & 120,360 & 4.0 & 30,090 & 854 & TS \\
\hline Tunisia & Tunis & 625,155 & 2.8 & 223,270 & 902 & TS \\
\hline Turkey & Antalya & $14,258,080$ & 4.0 & $3,564,520$ & 910 & TS \\
\hline United Kingdom & London & 709,673 & 4.0 & 177,418 & 415 & PS \\
\hline United States & LA, Indianapolis & $5,077,571$ & 6.0 & 846,262 & 646 & PS \\
\hline Uruguay & Montevideo & 12,571 & 4.0 & 3,143 & 682 & TS \\
\hline \multirow[t]{3}{*}{ Zimbabwe } & Harare & 19,568 & 4.0 & 4,892 & 854 & TS \\
\hline & TOTAL & $299,476,976$ & & $74,350,976$ & & \\
\hline & AVERAGE & & 4,3 & & 640 & \\
\hline
\end{tabular}

PS: pumped system

TS: thermosiphon system

PDS: pumped drain back system

Table 7: Solar thermal systems for domestic hot water heating in single family houses by end of 2012 
Figure 44 shows the hydraulic scheme used for the energy calculation for all pumped solar thermal systems and Figure 45 refers to the thermosiphon systems.

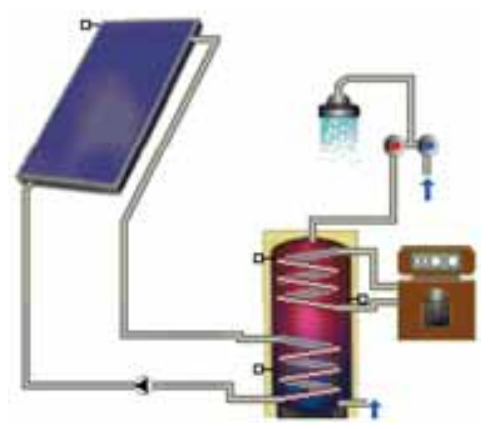

Figure 44: Hydraulic scheme of the domestic hot water pumped reference system for single family houses

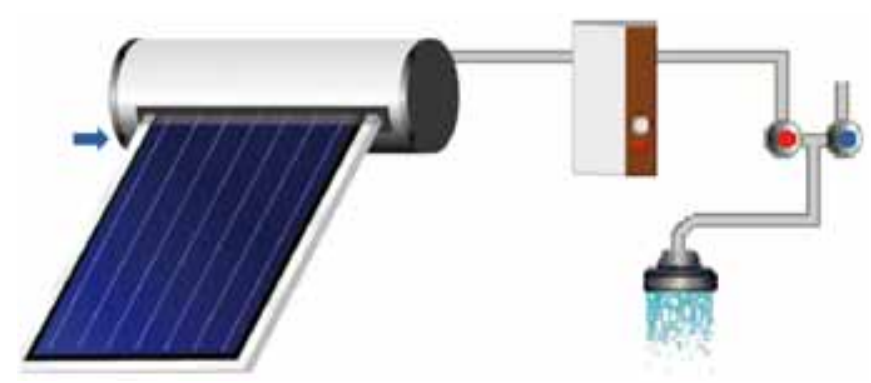

Figure 45: Hydraulic scheme of the domestic hot water thermosiphon reference system for single family houses

For the Chinese thermosiphon systems the reference system above was used, but instead of a flat plate collector as shown in Figure $\mathbf{4 5}$ a representative Chinese vacuum tube collector was used for the simulation. 


\subsubsection{Reference systems for domestic hot water preparation in multifamily houses}

The information in Table 8 refers to the total capacity of water collectors in operation used for domestic hot water heating in multifamily houses at the end of 2012 as reported by each country.

\begin{tabular}{|c|c|c|c|c|c|c|}
\hline Country & $\begin{array}{c}\text { Reference } \\
\text { climate }\end{array}$ & $\begin{array}{l}\text { Total collector } \\
\text { area }\left[\mathrm{m}^{2}\right]\end{array}$ & $\begin{array}{c}\text { Collector area } \\
\left.\text { per system [ } \mathbf{m}^{2}\right]\end{array}$ & $\begin{array}{l}\text { Total number of } \\
\text { systems }\end{array}$ & $\begin{array}{c}\text { Specific solar } \\
\text { yield }\left[\mathrm{kWh} / \mathrm{m}^{2} \mathrm{a}\right]\end{array}$ & $\begin{array}{l}\text { Type of } \\
\text { System }\end{array}$ \\
\hline Albania & Tirana & 80,057 & 50.0 & 1,601 & 694 & PS \\
\hline Australia & Sydney & 36,630 & 50.0 & 733 & 725 & PS \\
\hline Austria & Graz & 382,614 & 50.0 & 7,652 & 505 & PS \\
\hline Brazil & Brasília & 778,763 & 50.0 & 15,575 & 658 & PS \\
\hline Bulgaria & Sofia & 35,086 & 50.0 & 702 & 515 & PS \\
\hline Canada & Montreal & 295,842 & 50.0 & 5,917 & 621 & PS \\
\hline Chile & Santiago de Chile & 43,205 & 50.0 & 864 & 733 & PS \\
\hline China & Shanghai & $21,904,500$ & 50.0 & 438,090 & 502 & PS \\
\hline Cyprus & Nicosia & 102,162 & 50.0 & 2,043 & 750 & PS \\
\hline Czech Republic & Prague & 29,218 & 42.4 & 689 & 436 & PS \\
\hline Denmark & Copenhagen & 356,709 & 50.0 & 7,134 & 414 & PS \\
\hline France & Paris & $1,247,563$ & 20.0 & 62,378 & 489 & PS \\
\hline Germany & Wurzburg & $1,982,988$ & 50.0 & 39,660 & 472 & PS \\
\hline Greece & Athens & 148,392 & 50.0 & 2,968 & 642 & PS \\
\hline Hungary & Budapest & 17,498 & 50.0 & 350 & 522 & PS \\
\hline India & New-Delhi & $1,515,985$ & 50.0 & 30,320 & 749 & PS \\
\hline Ireland & Dublin & 8,159 & 50.0 & 163 & 425 & PS \\
\hline Israel & Jerusalem & $3,316,000$ & 3.0 & $1,105,333$ & 919 & PS \\
\hline Italy & Bologna & 620,418 & 50.0 & 12,408 & 593 & PS \\
\hline Japan & Tokyo & 89,231 & 50.0 & 1,785 & 516 & PS \\
\hline Jordan & Amman & 223,619 & 50.0 & 4,472 & 801 & PS \\
\hline Korea, South & Seoul & 775,019 & 50.0 & 15,500 & 485 & PS \\
\hline Lebanon & Beirut & 78,900 & 50.0 & 1,578 & 809 & PS \\
\hline Macedonia & Skopje & 13,644 & 50.0 & 273 & 577 & PS \\
\hline Mexico & Mexico City & 862,825 & 50.0 & 17,256 & 713 & PS \\
\hline Namibia & Windhoek & 12,103 & 50.0 & 242 & 814 & PS \\
\hline Netherlands & Amsterdam & 80,255 & 50.0 & 1,605 & 418 & PS \\
\hline Norway & Oslo & 16,749 & 50.0 & 335 & 406 & PS \\
\hline Poland & Warsaw & 302,875 & 50.0 & 6,058 & 447 & PS \\
\hline Portugal & Lisbon & 226,934 & 40.0 & 5,673 & 705 & PS \\
\hline Russia & Moscow & 16,926 & 50.0 & 339 & 416 & PS \\
\hline Slovenia & Ljubljana & 3,736 & 50.0 & 75 & 477 & PS \\
\hline South Africa & Johannesburg & 10,635 & 50.0 & 213 & 867 & PS \\
\hline Spain & Madrid & $1,422,156$ & 50.0 & 28,443 & 676 & PS \\
\hline Sweden & Gothenburg & 45,900 & 50.0 & 918 & 430 & PS \\
\hline Switzerland & Zürich & 84,316 & 20.0 & 4,216 & 457 & PS \\
\hline Taiwan & Taipei & 20,079 & 33.8 & 594 & 518 & PS \\
\hline Tunisia & Tunis & 14,063 & 50.0 & 281 & 756 & PS \\
\hline Turkey & Antalya & $1,239,833$ & 50.0 & 24,797 & 750 & PS \\
\hline \multirow[t]{3}{*}{ United States } & LA, Indianapolis & 32,484 & 50.0 & 650 & 688 & PS \\
\hline & TOTAL & $38,474,071$ & & $1,849,883$ & & \\
\hline & AVERAGE & & 46.5 & & 602 & \\
\hline
\end{tabular}

PS: pumped system

Table 8: Solar thermal systems for domestic hot water heating in multifamily houses by end of 2012

Figure $\mathbf{4 6}$ shows the hydraulic scheme of domestic hot water reference system for multifamily houses as used for the simulations of the solar energy yields. As opposed to small-scale domestic hot water systems, all large-scale systems are assumed to be pumped solar thermal systems.

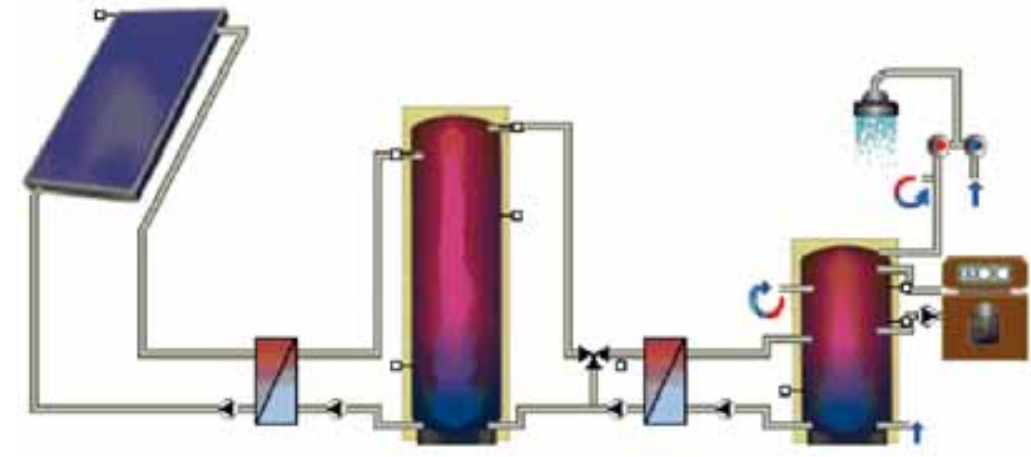

Figure 46: Hydraulic scheme of the domestic hot water pumped reference system for multifamily houses 


\subsubsection{Reference systems for domestic hot water preparation and space heating in single and multifamily houses (solar combi-systems)}

The information in Table 9 refers to the total capacity of water collectors in operation used for domestic hot water heating in multifamily houses at the end of 2012 as reported by each country.

\begin{tabular}{|c|c|c|c|c|c|c|}
\hline Country & $\begin{array}{c}\text { Reference } \\
\text { climate }\end{array}$ & $\begin{array}{l}\text { Total collector } \\
\text { area }\left[\mathrm{m}^{2}\right]\end{array}$ & $\begin{array}{c}\text { Collector area } \\
\left.\text { per system [ } \mathbf{m}^{2}\right]\end{array}$ & $\begin{array}{c}\text { Total number of } \\
\text { systems }\end{array}$ & $\begin{array}{c}\text { Specific solar } \\
\text { yield }\left[\mathrm{kWh} / \mathrm{m}^{2} \text { a] }\right.\end{array}$ & $\begin{array}{l}\text { Type of } \\
\text { System }\end{array}$ \\
\hline Austria & Graz & $1,935,121$ & 14.0 & 138,223 & 369 & PS \\
\hline China & Shanghai & $3,865,500$ & 12.0 & 322,125 & 388 & PS \\
\hline Cyprus & Nicosia & 14,214 & 12.0 & 1,184 & 663 & PS \\
\hline Czech Republic & Prague & 156,574 & 8.4 & 18,640 & 351 & PS \\
\hline Denmark & Copenhagen & 6,429 & 12.0 & 536 & 348 & PS \\
\hline France & Paris & 143,859 & 11.0 & 13,078 & 370 & PS \\
\hline Germany & Wurzburg & $6,956,712$ & 12.0 & 579,726 & 378 & PS \\
\hline Greece & Athens & 4,122 & 12.0 & 344 & 558 & PS \\
\hline Hungary & Budapest & 47,827 & 15.0 & 3,188 & 422 & PS \\
\hline Ireland & Dublin & 19,038 & 12.0 & 1,586 & 364 & PS \\
\hline Italy & Bologna & 517,015 & 12.0 & 43,085 & 499 & PS \\
\hline Netherlands & Amsterdam & 22,293 & 6.0 & 3,715 & 352 & PS \\
\hline Norway & Oslo & 16,323 & 20.0 & 816 & 342 & PS \\
\hline Poland & Warsaw & 60,575 & 12.0 & 5,048 & 365 & PS \\
\hline Portugal & Lisbon & 15,517 & 12.0 & 1,293 & 593 & PS \\
\hline Russia & Moscow & 459 & 15.0 & 31 & 350 & PS \\
\hline Slovenia & Ljubljana & 28,020 & 12.0 & 2,335 & 362 & PS \\
\hline Spain & Madrid & 237,026 & 10.0 & 23,703 & 619 & PS \\
\hline Sweden & Gothenburg & 239,850 & 10.0 & 23,985 & 389 & PS \\
\hline Switzerland & Zürich & 263,488 & 11.0 & 23,953 & 385 & PS \\
\hline \multirow[t]{3}{*}{ United States } & LA, Indianapolis & 504,759 & 12.0 & 42,063 & 579 & PS \\
\hline & TOTAL & $15,054,718$ & & $1,248,657$ & & \\
\hline & AVERAGE & & 12.5 & & 431 & \\
\hline
\end{tabular}

combi-system system for the supply of domestic hot water and space heating

PS: pumped system

Table 9: Solar combi system reference for single and multifamily houses and the total collector area in operation in 2011

Figure $\mathbf{4 7}$ shows the hydraulic scheme of domestic hot water reference system for multifamily houses as used for the simulations of the solar energy yields.

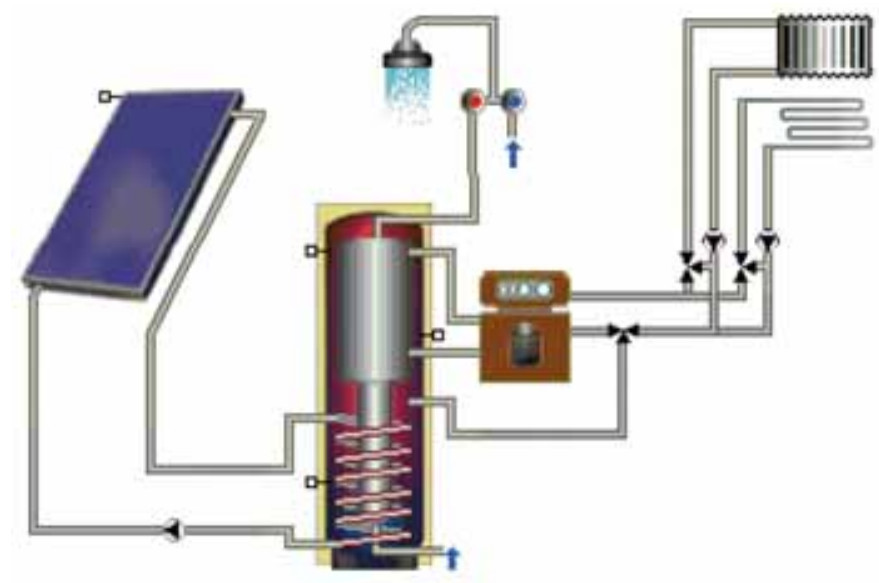

Figure 47: Hydraulic scheme of the solar-combi reference system for single and multifamily houses 


\subsection{Reference collectors}

8.2.1 Data of the reference unglazed water collector for swimming pool heating

$$
\eta=0.85 \quad a_{1}=20\left[\mathrm{~W} / \mathrm{m}^{2} \mathrm{~K}\right] \quad \mathrm{a}_{2}=0.1\left[\mathrm{~W} / \mathrm{m}^{2} \cdot \mathrm{K}^{2}\right]
$$

8.2.2 Data of the reference collector for all other applications except for China

$$
\eta=0.8 \quad a_{1}=3.69\left[\mathrm{~W} / \mathrm{m}^{2} \mathrm{~K}\right] \quad \mathrm{a}_{2}=0.007\left[\mathrm{~W} / \mathrm{m}^{2} \mathrm{~K}^{2}\right]
$$

\subsubsection{Data of the Chinese reference vacuum tube collector}

$$
\eta=0.74 \quad a_{1}=2.5\left[\mathrm{~W} / \mathrm{m}^{2} \mathrm{~K}\right] \quad \mathrm{a}_{2}=0.013\left[\mathrm{~W} / \mathrm{m}^{2} \mathrm{~K}^{2}\right]
$$

\begin{tabular}{|c|c|c|c|c|c|c|c|c|c|c|c|}
\hline & & & & & & & & & \\
\hline & & & 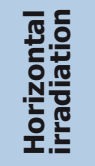 & 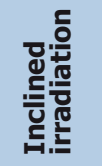 & 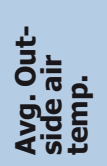 & & & & 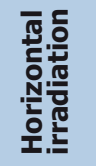 & 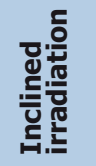 & 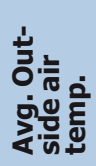 \\
\hline No. & Country & $\begin{array}{l}\text { Reference } \\
\text { climate }\end{array}$ & $\begin{array}{l}{[\mathrm{kWh} /} \\
\left.\mathrm{m}^{2} \cdot \mathrm{a}\right]\end{array}$ & $\begin{array}{l}{[\mathrm{kWh} /} \\
\left.\mathrm{m}^{2} \cdot \mathrm{a}\right]\end{array}$ & {$\left[{ }^{\circ} \mathrm{C}\right]$} & No. & Country & $\begin{array}{l}\text { Reference } \\
\text { climate }\end{array}$ & $\begin{array}{l}{[\mathrm{kWh} /} \\
\left.\mathrm{m}^{2} \cdot \mathrm{a}\right]\end{array}$ & $\begin{array}{l}{[\mathrm{kWh} /} \\
\left.\mathrm{m}^{2} \cdot \mathrm{a}\right]\end{array}$ & {$\left[{ }^{\circ} \mathrm{C}\right]$} \\
\hline 1 & Albania & Tirana & 1,604 & 1,835 & 13.5 & 30 & Lithuania & Vilnius & 1,001 & 1,161 & 6.2 \\
\hline 2 & Australia & Sydney & 1,674 & 1,841 & 18.1 & 31 & Luxembourg & Luxembourg & 1,037 & 1,158 & 8.4 \\
\hline 3 & Austria & Graz & 1,126 & 1,280 & 9.2 & 32 & Macedonia & Skopje & 1,381 & 1,521 & 12.5 \\
\hline 4 & Barbados & Grantley Adams & 2,016 & 2,048 & 27.4 & 33 & Malta & Luqa & 1,902 & 2,115 & 18.7 \\
\hline 5 & Belgium & Brussels & 971 & 1,095 & 10.0 & 34 & Mexico & Mexico City & 1,706 & 1,759 & 16.6 \\
\hline 6 & Brazil & Brasília & 1,793 & 1,838 & 22.0 & 35 & Morocco & Rabat & 2,011 & 2,281 & 17.2 \\
\hline 7 & Bulgaria & Sofia & 1,188 & 1,304 & 10.1 & 36 & Mozambique & Maputo & 1,927 & 2,135 & 22.8 \\
\hline 8 & Canada & Montreal & 1,351 & 1,568 & 6.9 & 37 & Namibia & Windhoek & 2,363 & 2,499 & 21.0 \\
\hline 9 & Chile & Santiago d. C. & 1,753 & 1,850 & 14.5 & 38 & Netherlands & Amsterdam & 999 & 1,131 & 10.0 \\
\hline 10 & China & Shanghai & 1,282 & 1,343 & 17.1 & 39 & New Zealand & Wellington & 1,401 & 1,542 & 13.6 \\
\hline 11 & Croatia & Zagreb & 1,212 & 1,352 & 11.3 & 40 & Norway & Oslo & 971 & 1,208 & 5.8 \\
\hline 12 & Cyprus & Nicosia & 1,886 & 2,098 & 19.9 & 41 & Poland & Warsaw & 1,024 & 1,156 & 8.1 \\
\hline 13 & Czech Rep. & Prague & 998 & 1,111 & 7.9 & 42 & Portugal & Lisbon & 1,686 & 1,875 & 17.4 \\
\hline 14 & Denmark & Copenhagen & 989 & 1,164 & 8.1 & 43 & Romania & Bucharest & 1,324 & 1,473 & 10.6 \\
\hline 15 & Estonia & Tallinn & 960 & 1,126 & 5.3 & 44 & Russia & Moscow & 996 & 1,181 & 5.9 \\
\hline 16 & Finland & Helsinki & 948 & 1,134 & 4.6 & 45 & Slovakia & Bratislava & 1,214 & 1,374 & 10.3 \\
\hline 17 & France & Paris & 1,112 & 1,246 & 11.0 & 46 & Slovenia & Ljubljana & 1,115 & 1,231 & 9.8 \\
\hline 18 & Germany & Wurzburg & 1,091 & 1,225 & 9.5 & 47 & South Africa & Johannesburg & 2,075 & 2,232 & 15.6 \\
\hline 19 & Greece & Athens & 1,585 & 1,744 & 18.5 & 48 & Spain & Madrid & 1,644 & 1,844 & 15.5 \\
\hline 20 & Hungary & Budapest & 1,199 & 1,346 & 11.0 & 49 & Sweden & Gothenburg & 934 & 1,105 & 7.2 \\
\hline 21 & India & New-Delhi & 1,961 & 2,275 & 24.7 & 50 & Switzerland & Zürich & 1,094 & 1,218 & 9.6 \\
\hline 22 & Ireland & Dublin & 949 & 1,091 & 9.5 & 51 & Taiwan & Taipei & 1,372 & 1,398 & 20.8 \\
\hline 23 & Israel & Jerusalem & 2,198 & 2,400 & 17.3 & 52 & Thailand & Bangkok & 1,765 & 1,898 & 29.1 \\
\hline 24 & Italy & Bologna & 1,419 & 1,592 & 14.3 & 53 & Tunisia & Tunis & 1,808 & 2,038 & 19.3 \\
\hline 25 & Japan & Tokyo & 1,175 & 1,287 & 16.7 & 54 & Turkey & Antalya & 1,795 & 1,958 & 18.4 \\
\hline 26 & Jordan & Amman & 2,145 & 2,341 & 17.9 & 55 & UK & London & 943 & 1,062 & 12.0 \\
\hline 27 & Korea, South & Seoul & 1,161 & 1,280 & 12.7 & 56 & USA & LA, Indianapolis & 1,646 & 1,816 & 14.3 \\
\hline 28 & Latvia & Riga & 991 & 1,187 & 6.3 & 57 & Uruguay & Montevideo & 1,534 & 1,647 & 15.9 \\
\hline 29 & Lebanon & Beirut & 1,935 & 2,132 & 19.9 & 58 & Zimbabwe & Harare & 2,017 & 2,087 & 18.9 \\
\hline
\end{tabular}

\subsection{Reference climates}

Source: T-Sol expert version 4.5 and Meteonorm version 6.1.

Table 10: Reference climates for the 58 countries surveyed 


\subsection{Population data}

\begin{tabular}{|c|c|c|c|c|c|c|c|}
\hline No & Country & 2012 & Region code & No & Country & 2012 & Region code \\
\hline 1 & Albania & $3,002,859$ & 6 & 32 & Macedonia & $2,082,370$ & 6 \\
\hline 2 & Australia & $22,015,580$ & 3 & 33 & Malta & 409,836 & 6 \\
\hline 3 & Austria & $8,219,743$ & 6 & 34 & Mexico & $117,299,200$ & 4 \\
\hline 4 & Barbados & 287,733 & 4 & 35 & Morocco & $32,309,240$ & 7 \\
\hline 5 & Belgium & $10,438,350$ & 6 & 36 & Mozambique & $23,515,930$ & 1 \\
\hline 6 & Brazil & $199,321,400$ & 4 & 37 & Namibia & $2,165,828$ & 1 \\
\hline 7 & Bulgaria & $7,037,935$ & 6 & 38 & Netherlands & $16,730,630$ & 6 \\
\hline 8 & Canada & $34,300,080$ & 8 & 39 & New Zealand & $4,327,944$ & 3 \\
\hline 9 & Chile & $17,067,370$ & 4 & 40 & Norway & $5,021,106$ & 6 \\
\hline 10 & China & $1,343,240,000$ & 5 & 41 & Poland & $38,415,280$ & 6 \\
\hline 11 & Croatia & $4,480,043$ & 6 & 42 & Portugal & $10,781,460$ & 6 \\
\hline 12 & Cyprus & $1,138,071$ & 6 & 43 & Romania & $21,848,500$ & 6 \\
\hline 13 & Czech Republic & $10,591,710$ & 6 & 44 & Russia & $142,517,670$ & 6 \\
\hline 14 & Denmark & $5,543,453$ & 6 & 45 & Slovakia & $5,483,088$ & 6 \\
\hline 15 & Estonia & $1,274,709$ & 6 & 46 & Slovenia & $1,996,617$ & 6 \\
\hline 16 & Finland & $5,262,930$ & 6 & 47 & South Africa & $48,810,430$ & 1 \\
\hline 17 & France (mainland) & $65,630,690$ & 6 & 48 & Spain & $47,042,980$ & 6 \\
\hline 18 & Germany & $81,305,860$ & 6 & 49 & Sweden & $9,573,256$ & 6 \\
\hline 19 & Greece & $10,767,830$ & 6 & 50 & Switzerland & $7,925,517$ & 6 \\
\hline 20 & Hungary & $9,958,453$ & 6 & 51 & Taiwan & $23,234,940$ & 2 \\
\hline 21 & India & $1,205,074,000$ & 2 & 52 & Thailand & $67,245,400$ & 2 \\
\hline 22 & Ireland & $4,722,028$ & 6 & 53 & Tunisia & $10,732,900$ & 7 \\
\hline 23 & Israel & $7,590,758$ & 7 & 54 & Turkey & $79,749,460$ & 6 \\
\hline 24 & Italy & $61,261,250$ & 6 & 55 & United Kingdom & $63,047,160$ & 6 \\
\hline 25 & Japan & $127,368,100$ & 2 & 56 & United States & $313,914,000$ & 8 \\
\hline 26 & Jordan & $6,508,887$ & 7 & 57 & Uruguay & $3,316,328$ & 4 \\
\hline 27 & Korea, South & $48,860,500$ & 2 & 58 & Zimbabwe & $12,619,600$ & 1 \\
\hline 28 & Latvia & $2,191,580$ & 6 & \multirow{3}{*}{\multicolumn{2}{|c|}{$\begin{array}{l}\sum \text { Solar Thermal } \\
\text { World Statistics }\end{array}$}} & & \\
\hline 29 & Lebanon & $4,140,289$ & 7 & & & $4,424,753,696$ & $63.0 \%$ \\
\hline 30 & Lithuania & $3,525,761$ & 6 & & & & \\
\hline 31 & Luxembourg & 509,074 & 6 & \multicolumn{2}{|c|}{$\sum$ Inhabitants world } & $7,020,760,225$ & $100.0 \%$ \\
\hline
\end{tabular}

Data source: International Data Base of the U.S. Census Bureau http://www.census.gov/ipc/www/idb/country.php

Table 11: Inhabitants by the end of 2012 of the 58 surveyed countries in alphabetical order

\begin{tabular}{|c|c|c|c|}
\hline \multicolumn{2}{|r|}{ Region Code / Region } & $\Sigma$ Inhabitants & Share \\
\hline 1 & Sub-Sahara Africa & $86,184,778$ & $2.0 \%$ \\
\hline 2 & Asia excl. China & $1,455,189,038$ & $34.3 \%$ \\
\hline 3 & Australia / New Zealand & $26,057,058$ & $0.6 \%$ \\
\hline 4 & Latin America & $337,637,999$ & $8.0 \%$ \\
\hline 5 & China & $1,336,718,015$ & $31.5 \%$ \\
\hline 6 & Europe & $598,744,151$ & $14.1 \%$ \\
\hline 7 & MENA Region & $60,721,971$ & $1.4 \%$ \\
\hline & United States / Canada & $345,081,566$ & $8.1 \%$ \\
\hline \multicolumn{2}{|r|}{ TOTAL } & $4,246,334,576$ & $100.0 \%$ \\
\hline
\end{tabular}

Data source: International Data Base of the U.S. Census Bureau http://www.census.gov/ipc/www/idb/country.php

Sub-Saharan Africa: Mozambique, Namibia, South Africa, Zimbabwe

Asia excluding China: India, Japan, Korea South, Taiwan, Thailand

Latin America: Brazil, Chile, Mexico, Uruguay

Europe: EU 28, Albania, Macedonia, Norway,

Switzerland, Russia, Turkey

MENA Region: Israel, Jordan, Lebanon, Morocco, Tunisia

Table 12: Inhabitants per economic region

by the end of 2011 


\subsection{Market data of the previous years}

The data presented in Chapters 3 - 5 were originally collected in square meters. Through an agreement of international experts the collector areas of these solar thermal applications have been converted and are shown in installed capacity as well.

Making the installed capacity of solar thermal collectors comparable with that of other energy sources, solar thermal experts from seven countries agreed upon a methodology to convert installed collector area into solar thermal capacity.

The methodology was developed during a meeting with IEA SHC Programme officials and major solar thermal trade associations in Gleisdorf, Austria in September 2004. The represented associations from Austria, Canada, Germany, the Netherlands, Sweden and the United States as well as the European Solar Thermal Industry Federation (ESTIF) and the IEA SHC Programme agreed to use a factor of $0.7 \mathrm{~kW}$ th $/ \mathrm{m}^{2}$ to derive the nominal capacity from the area of installed collectors.

In order to ensure consistency of the calculations within this report the following tables provide data from the previous years. If necessary the numbers have been revised in 2013 compared to the data originally published in earlier editions of this report due to changes in methodology or the origin of the data for each country.

In the following Table 13, Table 14 and Table 15 these countries are highlighted accordingly and in Chapter $\mathbf{8 . 6}$ (References) the respective data source is cited. 


\begin{tabular}{|c|c|c|c|c|c|c|}
\hline \multirow{2}{*}{ Country } & \multicolumn{3}{|c|}{ Water Collectors } & \multicolumn{2}{|c|}{ Air Collectors } & \multirow{2}{*}{ TOTAL $\left[\mathrm{m}^{2}\right]$} \\
\hline & unglazed & FPC & ETC & unglazed & glazed & \\
\hline Albania & & 7,480 & 82 & & & 7,562 \\
\hline Australia & 680,000 & 362,351 & 35,837 & & & $1,078,188$ \\
\hline Austria & 5,539 & 268,093 & 11,805 & 350 & & 285,787 \\
\hline \multicolumn{7}{|l|}{ Barbados** } \\
\hline Belgium & & 31,306 & 6,995 & & & 38,301 \\
\hline Brazil & 493,725 & 472,956 & & & & 966,681 \\
\hline Bulgaria & & 7,750 & 650 & & & 8,400 \\
\hline Canada & 84,690 & 11,481 & 11,493 & 89,560 & 2,267 & 199,491 \\
\hline Chile* & & 10,920 & & & & 10,920 \\
\hline China & & $3,000,000$ & $46,000,000$ & & & $49,000,000$ \\
\hline Croatia \# & & 11,250 & & & & 11,250 \\
\hline Cyprus & 109 & 32,931 & 1,782 & & & 34,822 \\
\hline Czech Republic & 53,000 & 73,898 & 17,719 & & & 144,617 \\
\hline Denmark & & 61,944 & 400 & & & 62,344 \\
\hline Estonia & & 100 & 400 & & & 500 \\
\hline Finland & & 4,000 & 2,000 & & & 6,000 \\
\hline France (mainland) & & 247,000 & 9,000 & & & 256,000 \\
\hline Germany & & $1,038,000$ & 112,000 & & & $1,150,000$ \\
\hline Greece & & 212,500 & 1,500 & & & 214,000 \\
\hline Hungary & 2,400 & 14,700 & 6,300 & 300 & 150 & 23,850 \\
\hline India & & 608,436 & 280,369 & & & 888,805 \\
\hline Ireland & & 17,472 & 13,109 & & & 30,581 \\
\hline Israel & & 316,000 & & & & 316,000 \\
\hline Italy & & 427,500 & 62,500 & & & 490,000 \\
\hline Japan & & 146,866 & 4,794 & & 11,850 & 163,511 \\
\hline Jordan & 5,940 & 79,621 & 12,654 & & & 98,215 \\
\hline Korea, South & & 69,803 & & & & 69,803 \\
\hline Latvia & & 100 & 100 & & & 200 \\
\hline \multicolumn{7}{|l|}{ Lebanon** } \\
\hline Lithuania & & 50 & 150 & & & 200 \\
\hline Luxembourg & & 3,500 & 1,000 & & & 4,500 \\
\hline \multicolumn{7}{|l|}{ Macedonia** } \\
\hline Malta & & 1,759 & 1,101 & & & 2,860 \\
\hline Mexico & 90,000 & 95,000 & 85,000 & & 2,580 & 272,580 \\
\hline Morocco & & 69,260 & & & & 69,260 \\
\hline \multicolumn{7}{|l|}{ Mozambique** } \\
\hline Namibia & & 5,440 & 860 & & & 6,300 \\
\hline Netherlands & 26,507 & 45,862 & 4,000 & & & 76,369 \\
\hline \multicolumn{7}{|l|}{ New Zealand** } \\
\hline Norway & 170 & 2,123 & 813 & & & 3,106 \\
\hline Poland & & 111,000 & 35,000 & & & 146,000 \\
\hline Portugal & 353 & 186,990 & 302 & & & 187,645 \\
\hline Romania & & 8,500 & 7,000 & & & 15,500 \\
\hline \multicolumn{7}{|l|}{ Russia** } \\
\hline Slovakia & & 12,800 & 2,200 & & & 15,000 \\
\hline Slovenia & & 15,000 & 4,000 & & & 19,000 \\
\hline South Africa & 50,000 & 42,300 & 7,700 & & & 100,000 \\
\hline Spain & 11,000 & 315,500 & 21,500 & & & 348,000 \\
\hline Sweden & 17,191 & 13,567 & 7,132 & & & 37,890 \\
\hline Switzerland & 11,944 & 129,026 & 15,746 & 8,000 & & 164,716 \\
\hline Taiwan & 2 & 115,938 & 11,811 & & & 127,751 \\
\hline Thailand* & & 18,200 & & & & 18,200 \\
\hline Tunisia & & 72,200 & 12,500 & & & 84,700 \\
\hline Turkey* & & $1,333,970$ & 348,000 & & & $1,681,970$ \\
\hline United Kingdom & & 75,600 & 29,600 & & & 105,200 \\
\hline United States & 937,856 & 225,383 & & & & $1,163,239$ \\
\hline \multicolumn{7}{|l|}{ Uruguay** } \\
\hline Zimbabwe & & 450 & 75 & & & 525 \\
\hline TOTAL & $2,470,426$ & $10,433,875$ & $47,186,980$ & 98,210 & 16,847 & $60,106,338$ \\
\hline
\end{tabular}

* revised due to new / adapted database in 2014

\# added in 2014

** no available data for the year 2010

Table 13: Newly installed collector area in 2010 (revised 2014) [m²/a] 


\begin{tabular}{|c|c|c|c|c|c|c|}
\hline \multirow{2}{*}{ Country } & \multicolumn{3}{|c|}{ Water Collectors } & \multicolumn{2}{|c|}{ Air Collectors } & \multirow{2}{*}{ TOTAL $\left[\mathrm{m}^{2}\right]$} \\
\hline & unglazed & glazed & evacuated tube & unglazed & glazed & \\
\hline Albania & & 12,890 & 98 & & & 12,988 \\
\hline Australia & 600,000 & 343,980 & 22,230 & 36,000 & 900 & $1,003,110$ \\
\hline Austria & 5,700 & 221,500 & 8,690 & & 350 & 236,240 \\
\hline \multicolumn{7}{|l|}{ Barbados** } \\
\hline Belgium & & 35,500 & 10,000 & & & 45,500 \\
\hline Brazil & 512,099 & 517,517 & & & & $1,029,616$ \\
\hline Bulgaria & & 10,000 & 800 & & & 10,800 \\
\hline Canada & 74,490 & 7,880 & 9,500 & 28,377 & 7,165 & 127,412 \\
\hline Chile* & & 19,037 & & & & 19,037 \\
\hline China & & $2,880,000$ & $54,720,000$ & & & $57,600,000$ \\
\hline Croatia \# & & 14,500 & & & & 14,500 \\
\hline Cyprus & 142 & 26,794 & 1,643 & & & 28,579 \\
\hline Czech Republic & 65,000 & 49,150 & 16,650 & & & 130,800 \\
\hline Denmark & & 61,897 & 504 & & & 62,401 \\
\hline Estonia & & 900 & 900 & & & 1,800 \\
\hline Finland & & 3,000 & 1,000 & & & 4,000 \\
\hline France (mainland) & & 242,200 & 8,800 & 553 & 117 & 251,670 \\
\hline Germany & & $1,152,000$ & 118,000 & 428 & & $1,270,428$ \\
\hline Greece & & 230,000 & & & & 230,000 \\
\hline Hungary & 1,500 & 14,000 & 6,000 & 300 & 250 & 22,050 \\
\hline India & & 606,000 & 404,000 & & & $1,010,000$ \\
\hline Ireland & & 12,538 & 8,232 & & & 20,770 \\
\hline Israel & 2,500 & 370,984 & & & & 373,484 \\
\hline Italy & & 339,300 & 50,700 & & & 390,000 \\
\hline Japan & & 155,264 & 1,802 & & 10,773 & 167,839 \\
\hline Jordan & & 54,531 & 13,705 & & & 68,236 \\
\hline Korea, South & & 54,733 & & & & 54,733 \\
\hline Latvia & & 1,000 & 800 & & & 1,800 \\
\hline Lebanon* & & 40,000 & 20,000 & & & 60,000 \\
\hline Lithuania & & 600 & 1,200 & & & 1,800 \\
\hline Luxembourg & & 3,500 & 1,000 & & & 4,500 \\
\hline \multicolumn{7}{|l|}{ Macedonia** } \\
\hline Malta & & 2,335 & 480 & & & 2,815 \\
\hline Mexico & 90,000 & 95,000 & 85,000 & 300 & & 270,300 \\
\hline Morocco & & 71,429 & & & & 71,429 \\
\hline Mozambique & & & 130 & & & 130 \\
\hline \multicolumn{7}{|l|}{ Namibia** } \\
\hline Netherlands & 27,396 & 31,445 & 5,000 & & & 63,841 \\
\hline \multicolumn{7}{|l|}{ New Zealand** } \\
\hline Norway & 160 & 2,863 & 946 & & & 3,969 \\
\hline Poland & & 187,400 & 66,300 & & & 253,700 \\
\hline Portugal & 235 & 126,227 & 736 & 204 & & 127,402 \\
\hline Romania & & 8,500 & 7,000 & & & 15,500 \\
\hline \multicolumn{7}{|l|}{ Russia** } \\
\hline Slovakia & & 19,320 & 3,680 & & & 23,000 \\
\hline Slovenia & & 9,000 & 3,000 & & & 12,000 \\
\hline South Africa & 48,200 & 42,811 & 39,300 & & & 130,311 \\
\hline Spain & 8,600 & 249,700 & 17,250 & 1,500 & & 277,050 \\
\hline Sweden & 22,601 & 15,654 & 5,153 & & & 43,408 \\
\hline Switzerland & 9,040 & 129,142 & 8,721 & 9,000 & & 155,903 \\
\hline Taiwan & & 100,386 & 11,061 & & & 111,447 \\
\hline Thailand* & & 18,900 & & & & 18,900 \\
\hline Tunisia & & 64,300 & 8,000 & & & 72,300 \\
\hline Turkey* & & $1,301,075$ & 504,600 & 1,570 & & $1,807,245$ \\
\hline United Kingdom & & 72,953 & 18,826 & 5,597 & & 97,376 \\
\hline United States & 747,900 & 220,000 & 11,400 & 15,500 & 6,000 & $1,000,800$ \\
\hline \multicolumn{7}{|l|}{ Uruguay* } \\
\hline Zimbabwe & & 230 & 320 & & & 550 \\
\hline TOTAL & $2,215,563$ & $10,249,865$ & $56,223,156$ & 99,329 & 25,555 & $68,813,468$ \\
\hline
\end{tabular}

* revised due to new / adapted database in 2013

\# added in 2014

** no available data for the year 2011

Table 14: Newly installed collector area in 2011 (revised 2014) [m²/a] 


\begin{tabular}{|c|c|c|c|c|c|c|}
\hline \multirow{2}{*}{ Country } & \multicolumn{3}{|c|}{ Water Collectors } & \multicolumn{2}{|c|}{ Air Collectors } & \multirow{2}{*}{ TOTAL $\left[\mathrm{m}^{2}\right]$} \\
\hline & unglazed & glazed & evacuated tube & unglazed & glazed & \\
\hline Albania & & 90,075 & 646 & & & 90,721 \\
\hline Australia & $3,900,000$ & $2,642,000$ & 46,000 & 264,000 & 6,600 & $6,858,600$ \\
\hline Austria & 586,191 & $4,101,100$ & 74,926 & & 1,078 & $4,763,295$ \\
\hline Barbados & & 131,690 & & & & 131,690 \\
\hline Belgium & 45,000 & 289,888 & 33,395 & & & 368,283 \\
\hline Brazil & $1,789,227$ & $5,351,866$ & & & & $7,141,093$ \\
\hline Bulgaria* & & 112,650 & 1,450 & & & 114,100 \\
\hline Canada & 719,364 & 55,316 & 27,921 & 334,426 & 11,781 & $1,148,808$ \\
\hline Chile* & & 58,116 & & & & 58,116 \\
\hline China & & $14,787,370$ & $202,612,630$ & & & $217,400,000$ \\
\hline Croatia \# & & 105,500 & & & & 105,500 \\
\hline Cyprus & 2,123 & 845,449 & 21,656 & & & 869,228 \\
\hline Czech Republic & 418,000 & 299,743 & 74,925 & & & 792,668 \\
\hline Denmark & 20,515 & 583,707 & 8,588 & 3,264 & 18,000 & 634,074 \\
\hline Estonia & & 3,030 & 1,690 & & & 4,720 \\
\hline Finland & 11,779 & 27,251 & 5,472 & & & 44,502 \\
\hline France (mainland) & 90,000 & $1,995,094$ & 33,379 & & & $2,118,473$ \\
\hline Germany & 610,000 & $13,386,000$ & $1,718,000$ & & 32,000 & $15,746,000$ \\
\hline Greece & & $4,105,700$ & 16,300 & & & $4,122,000$ \\
\hline Hungary & 12,000 & 133,700 & 36,100 & 1,500 & 1,200 & 184,500 \\
\hline India & & $4,457,384$ & 522,616 & & 16,320 & $4,996,320$ \\
\hline Ireland & & 116,539 & 57,319 & & & 173,858 \\
\hline Israel & 30,617 & $4,234,498$ & & 550 & & $4,265,665$ \\
\hline Italy & 43,766 & $2,673,510$ & 399,490 & & & $3,116,766$ \\
\hline Japan & & $4,594,313$ & 83,753 & & 475,199 & $5,153,265$ \\
\hline Jordan & 5,940 & 818,889 & 230,969 & & & $1,055,798$ \\
\hline Korea, South & & $1,621,050$ & & & & $1,621,050$ \\
\hline Latvia & & 2,700 & 1,040 & & & 3,740 \\
\hline Lebanon & & 190,000 & 270,000 & & & 460,000 \\
\hline Lithuania & & 2,700 & 1,500 & & & 4,200 \\
\hline Luxembourg & & 31,800 & 3,850 & & & 35,650 \\
\hline Macedonia & & 25,020 & 724 & & & 25,744 \\
\hline Malta & & 34,502 & 11,782 & & & 46,284 \\
\hline Mexico & 722,008 & 777,055 & 230,813 & & 7,983 & $1,737,859$ \\
\hline Morocco* & & 412,689 & & & & 412,689 \\
\hline Mozambique \# & & 130 & & & & 130 \\
\hline Namibia & & 20,699 & 1,307 & & & 22,006 \\
\hline Netherlands & 410,239 & 418,478 & 14,000 & & & 842,717 \\
\hline New Zealand & 7,025 & 142,975 & 9,644 & & & 159,645 \\
\hline Norway & 2,090 & 16,885 & 1,958 & & 1,019 & 21,952 \\
\hline Poland & & 694,000 & 215,500 & & & 909,500 \\
\hline Portugal & 1,946 & 861,963 & 15,000 & & & 878,909 \\
\hline Romania* & & 72,200 & 23,000 & & & 95,200 \\
\hline Russia \# & & 11,504 & 1,010 & & & 12,514 \\
\hline Slovakia & & 119,420 & 20,080 & & & 139,500 \\
\hline Slovenia & & 154,050 & 16,250 & & & 170,300 \\
\hline South Africa & 851,878 & 373,821 & 67,972 & & & $1,293,671$ \\
\hline Spain & 130,600 & $2,450,200$ & 154,750 & & & $2,735,550$ \\
\hline Sweden & 130,000 & 256,000 & 60,000 & & & 446,000 \\
\hline Switzerland & 212,260 & 864,440 & 61,160 & 876,000 & & $2,013,860$ \\
\hline Taiwan & 85 & $2,070,686$ & 86,522 & & & $2,157,294$ \\
\hline Thailand* & & 97,700 & & & & 97,700 \\
\hline Tunisia & & 518,800 & 44,000 & & & 562,800 \\
\hline Turkey & & $13,185,391$ & $1,333,970$ & & & $14,519,361$ \\
\hline United Kingdom & & 490,097 & 160,301 & 14,000 & & 664,398 \\
\hline United States & $19,980,762$ & $2,502,284$ & 105,232 & 84,685 & 6,000 & $22,678,963$ \\
\hline Uruguay & & 12,571 & & & & 12,571 \\
\hline Zimbabwe & & 17,959 & 237 & & & 18,196 \\
\hline TOTAL 2010 & $30,733,415$ & $94,450,147$ & $208,918,828$ & $1,578,425$ & 577,180 & $336,257,996$ \\
\hline
\end{tabular}

* revised due to new / adapted database in 2013

\# added in 2014

** no available data for the year 2012

Table 15: Total collector area in operation by the end of 2011 (revised 2014) [m²] 


\subsection{References to reports and persons that have supplied the data}

The production of the report, Solar Heat Worldwide 2012 -2014 edition was kindly supported by national representatives of the recorded countries or other official sources of information as cited below.

\begin{tabular}{|c|c|c|}
\hline COUNTRY & CONTACT & $\begin{array}{l}\text { SOURCE } \\
\text { REMARKS }\end{array}$ \\
\hline AlbaniaAlbania & $\begin{array}{l}\text { Edmond M. HIDO } \\
\text { EEC - Albania-EU Energy Efficiency Centre (EEC) }\end{array}$ & EEC - Albania-EU Energy Efficiency Centre \\
\hline Australia & $\begin{array}{l}\text { David Ferrari } \\
\text { Sustainability Victoria }\end{array}$ & $\begin{array}{l}\text { Sustainability Victoria } \\
\text { Out of operation systems calculated by Sustainability Victoria }\end{array}$ \\
\hline Austria & $\begin{array}{l}\text { Werner Weiss } \\
\text { AEE - Institute for Sustainable Technologies }\end{array}$ & $\begin{array}{l}\text { Biermayr et al., } 2013 \\
\text { http://www.nachhaltigwirtschaften.at/iea/results.html/id7253 } \\
\text { Out of operation systems calculated by AEE INTEC }\end{array}$ \\
\hline Belgium & $\begin{array}{l}\text { ESTIF - European Solar Thermal } \\
\text { Industry Federation } \\
\text { AEE INTEC }\end{array}$ & $\begin{array}{l}\text { Glazed water collectors: ESTIF, } 2013 \\
\text { http://www.estif.org/statistics/st_markets_in_europe_2012/ } \\
\text { Unglazed water collectors: AEE INTEC recordings } \\
\text { Unglazed water collectors: AEE INTEC recordings }\end{array}$ \\
\hline Brazil & $\begin{array}{l}\text { Marcelo Mesquita } \\
\text { Depto. Nac. de } \\
\text { Aquecimento Solar da ABRAVA }\end{array}$ & $\begin{array}{l}\text { DASOL ABRAVA } \\
\text { Out of operation systems calculated based on DASOL ABRAVA } \\
\text { long time recordings }\end{array}$ \\
\hline Bulgaria & $\begin{array}{l}\text { ESTIF - European Solar Thermal } \\
\text { Industry Federation } \\
\text { AEE INTEC }\end{array}$ & $\begin{array}{l}\text { Glazed water collectors: ESTIF, } 2013 \text { (estimation) } \\
\text { http://www.estif.org/statistics/st_markets_in_europe_2012/ } \\
\text { Unglazed water collectors: AEE INTEC recordings } \\
\text { http://www.estif.org/statistics/st_markets_in_europe_2012/ }\end{array}$ \\
\hline Canada & $\begin{array}{l}\text { Reda Djebbar } \\
\text { Natural Resources Canada }\end{array}$ & $\begin{array}{l}\text { ClearSky Advisors Inc. Survey of Active Solar } \\
\text { Thermal Collectors, Industry and Markets in } \\
\text { Canada (2012) } \\
\text { http://www.cansia.ca/sites/default/files/survey_of_active_ } \\
\text { solar_thermal_collectors_-_2012_-_july_17.pdf } \\
\text { Out of operation systems considered }\end{array}$ \\
\hline
\end{tabular}

\section{Chile}

China Hu Runqing

Center for Renewable Energy Development Energy Research Institute (NDRC)

$\begin{array}{ll}\text { Croatia } & \text { ESTIF - European Solar Thermal } \\ & \text { Industry Federation }\end{array}$

Cyprus Soteris Kalogirou

Cyprus University of Technology
AEE INTEC, 2014 (estimation)

Projected by AEE INTEC ( $0 \%$ growth rate 2011 / 2012)

CSTIF - Chinese Solar Thermal Industry Federation Out of operation systems calculated by CSTIF

Glazed water collectors: ESTIF, 2013

http://www.estif.org/statistics/st_markets_in_europe_2012/

Cyprus University of Technology;

Energy Service, Ministry of Commerce, Industry \& Tourism, Cyprus

Out of operation systems considered for flat plate collectors only by AEE INTEC

\section{Czech Republic Ales Bufka}

Ministry of Industry and Trade
Ministry of Industry and Trade; Bufka, A.: Solar

collectors in 2012 - statistical review 


\begin{tabular}{|c|c|c|}
\hline Denmark & $\begin{array}{l}\text { ESTIF - European Solar Thermal } \\
\text { Industry Federation } \\
\text { AEE INTEC }\end{array}$ & $\begin{array}{l}\text { Glazed water collectors: ESTIF, } 2013 \\
\text { http://www.estif.org/statistics/st_markets_in_europe_2012/ } \\
\text { Unglazed water collectors: AEE INTEC recordings }\end{array}$ \\
\hline Estonia & $\begin{array}{l}\text { ESTIF - European Solar Thermal } \\
\text { Industry Federation }\end{array}$ & $\begin{array}{l}\text { Glazed water collectors: ESTIF, } 2013 \text { (estimation) } \\
\text { http://www.estif.org/statistics/st_markets_in_europe_2012/ }\end{array}$ \\
\hline Finland & $\begin{array}{l}\text { ESTIF - European Solar Thermal } \\
\text { Industry Federation } \\
\text { AEE INTEC }\end{array}$ & $\begin{array}{l}\text { Glazed water collectors: ESTIF, } 2013 \text { (estimation) } \\
\text { http://www.estif.org/statistics/st_markets_in_europe_2012/ } \\
\text { Unglazed water collectors: AEE INTEC recordings }\end{array}$ \\
\hline France (mainland) & $\begin{array}{l}\text { Céline Coulaud } \\
\text { ADEME - Centre de Sophia Antipolis } \\
\text { John Hollick } \\
\text { SAHWIA - Solar Air Heating World Industry Associ }\end{array}$ & $\begin{array}{l}\text { Glazed water collectors: ADEME; Enerplan } \\
\text { Unglazed water collectors: AEE INTEC recordings } \\
\text { Air collectors: SAHWIA } \\
\text { ation }\end{array}$ \\
\hline Germany & $\begin{array}{l}\text { Jan Knaack } \\
\text { BSW - Bundesverband Solarwirtschaft e.V. } \\
\text { John Hollick } \\
\text { SAHWIA - Solar Air Heating World Industry Associ }\end{array}$ & $\begin{array}{l}\text { Glazed water collectors: BSW } \\
\text { Unglazed water collectors: AEE INTEC recordings } \\
\text { http://www.solarwirtschaft.de/unsere-themen/ } \\
\text { zahlen-und-fakten.html } \\
\text { Out of operation systems considered for unglazed water } \\
\text { collectors only by AEE INTEC } \\
\text { Air collectors: SAHWIA } \\
\text { lation }\end{array}$ \\
\hline Greece & $\begin{array}{l}\text { Vassiliki Drosou } \\
\text { CRES - Centre for Renewable Energy Sources }\end{array}$ & Vassiliki Drosou (CRES), Costas Travasoras (EBHE) \\
\hline Hungary & $\begin{array}{l}\text { Pál Varga } \\
\text { MÉGNAP- Hungarian Solar Thermal Industry } \\
\text { Federation }\end{array}$ & $\begin{array}{l}\text { MÉGNAP- Hungarian Solar Thermal Industry } \\
\text { Federation }\end{array}$ \\
\hline India & $\begin{array}{l}\text { Jaideep N. Malaviya } \\
\text { Malaviya Solar Energy Consultancy }\end{array}$ & $\begin{array}{l}\text { Malaviya Solar Energy Consultancy } \\
\text { (based on market survey) }\end{array}$ \\
\hline Ireland & $\begin{array}{l}\text { Mary Holland } \\
\text { Sustainable Energy Authority of Ireland }\end{array}$ & $\begin{array}{l}\text { Energy policy statistical support unit of Sustainable } \\
\text { Energy Authority of Ireland } \\
\text { Based on Grant scheme data; BER database }\end{array}$ \\
\hline Israel & $\begin{array}{l}\text { Asher Vaturi } \\
\text { ICTAF - Israel Bureau of Statistics }\end{array}$ & $\begin{array}{l}\text { Israel Bureau of Statistics, Israel Ministry of water } \\
\text { and energy \& The Max Stern Yezreel Valley College } \\
\text { Out of operation systems (replacements) considered by ICTAF }\end{array}$ \\
\hline Italy & $\begin{array}{l}\text { Valeria Verga } \\
\text { Assolterm - Associazione Italiana Solare Termico }\end{array}$ & $\begin{array}{l}\text { Glazed water collectors: Assolterm processing of } \\
\text { data by Price Waterhouse Coopers } \\
\text { Unglazed water collectors: AEE INTEC recordings }\end{array}$ \\
\hline Japan & $\begin{array}{l}\text { Yamashita Noriaki } \\
\text { ISEP - Institute for Sustainable Energy Policies }\end{array}$ & $\begin{array}{l}\text { ISEP; Solar System Development Association } \\
\text { (SSDA) } \\
\text { Out of operation systems calculated by ISEP }\end{array}$ \\
\hline
\end{tabular}

Jordan

AEE INTEC, 2014 (estimation)

Projected by AEE INTEC ( $0 \%$ growth rate 2011 / 2012)

Korea, South

2012 New \& Renewable Energy Statistics by the Korea New \& Renewable Energy Center, 2013 http://solarthermalworld.org/content/south-korea-renewablebuilding-obligation-increases-market-size 


\begin{tabular}{|c|c|c|}
\hline Latvia & $\begin{array}{l}\text { ESTIF - European Solar Thermal } \\
\text { Industry Federation }\end{array}$ & $\begin{array}{l}\text { Glazed water collectors: ESTIF, } 2013 \text { (estimation) } \\
\text { http://www.estif.org/statistics/st_markets_in_europe_2012/ }\end{array}$ \\
\hline Lebanon & & $\begin{array}{l}\text { AEE INTEC, } 2014 \text { (estimation) } \\
\text { Projected by AEE INTEC ( } 10 \% \text { growth rate } 2011 \text { / 2012) }\end{array}$ \\
\hline Lithuania & $\begin{array}{l}\text { ESTIF - European Solar Thermal } \\
\text { Industry Federation }\end{array}$ & $\begin{array}{l}\text { Glazed water collectors: ESTIF, } 2013 \text { (estimation) } \\
\text { http://www.estif.org/statistics/st_markets_in_europe_2012/ }\end{array}$ \\
\hline Luxembourg & $\begin{array}{l}\text { ESTIF - European Solar Thermal } \\
\text { Industry Federation }\end{array}$ & $\begin{array}{l}\text { Glazed water collectors: ESTIF, } 2013 \text { (estimation) } \\
\text { http://www.estif.org/statistics/st_markets_in_europe_2012/ }\end{array}$ \\
\hline Malta & $\begin{array}{l}\text { Godwin Sant } \\
\text { Malta Resources Authority }\end{array}$ & Malta Resources Authority \\
\hline Mexico & & $\begin{array}{l}\text { ANES - Asociación Nacional de Energía Solar } \\
\text { http://solarthermalworld.org/print/62486 }\end{array}$ \\
\hline Morocco & & $\begin{array}{l}\text { AEE INTEC, } 2014 \text { (estimation) } \\
\text { Projected by AEE INTEC ( } 10 \% \text { growth rate } 2011 \text { / 2012) }\end{array}$ \\
\hline Mozambique & $\begin{array}{l}\text { Unpublished sources, } \\
\text { provided by Geraldo Nhumaio }\end{array}$ & SOLTRAIN survey \\
\hline Netherlands & $\begin{array}{l}\text { Reinoud Segers } \\
\text { Statistics Netherlands (CBS) }\end{array}$ & $\begin{array}{l}\text { Statistics Netherlands (CBS) } \\
\text { Cumulated areas: Statistics Netherlands based on survey of } \\
\text { sales. Market Shares: Expert Estimates NL Agency. }\end{array}$ \\
\hline Norway & $\begin{array}{l}\text { Peter Bernhard } \\
\text { Asplan Viak AS - KanEnergi }\end{array}$ & Asplan Viak AS - KanEnergi \\
\hline Poland & $\begin{array}{l}\text { Aneta Wiecka } \\
\text { EC BREC Institute for Renewable Energy (EC BREC }\end{array}$ & $\begin{array}{l}\text { EC BREC IEO } \\
\text { (IEO) }\end{array}$ \\
\hline Portugal & $\begin{array}{l}\text { João Farinha Mendes } \\
\text { APISOLAR - Associação Portuguesa da } \\
\text { Indústria Solar }\end{array}$ & $\begin{array}{l}\text { APISOLAR (www.apisolar.pt); „Oservatório Solar : } \\
\text { Estatisticas Solar Termico 2012" } \\
\text { http://www.aguaquentesolar.com/_fich/18/ } \\
\text { ST-Pt2012_fntApisolar.pdf }\end{array}$ \\
\hline Romania & $\begin{array}{l}\text { ESTIF - European Solar Thermal } \\
\text { Industry Federation }\end{array}$ & $\begin{array}{l}\text { Glazed water collectors: ESTIF, } 2013 \text { (estimation) } \\
\text { http://www.estif.org/statistics/st_markets_in_europe_2012/ }\end{array}$ \\
\hline Russia & $\begin{array}{l}\text { Semen Frid, Sophia Kiseleva } \\
\text { Moscow State University } \\
\text { Vitaly Butuzov } \\
\text { Yuzhgeoteplo corporation, Krasnodar }\end{array}$ & Moscow State University \\
\hline Slovakia & $\begin{array}{l}\text { ESTIF - European Solar Thermal } \\
\text { Industry Federation }\end{array}$ & $\begin{array}{l}\text { Glazed water collectors: ESTIF, } 2013 \\
\text { http://www.estif.org/statistics/st_markets_in_europe_2012/ }\end{array}$ \\
\hline Slovenia & $\begin{array}{l}\text { ESTIF - European Solar Thermal } \\
\text { Industry Federation }\end{array}$ & $\begin{array}{l}\text { Glazed water collectors: ESTIF, } 2013 \\
\text { http://www.estif.org/statistics/st_markets_in_europe_2012/ }\end{array}$ \\
\hline South Africa & $\begin{array}{l}\text { Dieter Holm } \\
\text { SOLTRAIN coordinator Southern Africa and } \\
\text { SESSA organiser for Gauteng }\end{array}$ & $\begin{array}{l}\text { Eskom's"Dashboard"(2008-2011); Raj Pandaram } \\
\text { (2013); } \\
\text { SOLTRAIN2 survey in Gauteng (2013) }\end{array}$ \\
\hline Spain & $\begin{array}{l}\text { Pascual Polo } \\
\text { ASIT - Asociación Solar de la Industria Térmica }\end{array}$ & $\begin{array}{l}\text { ASIT - Asociación Solar de la Industria Térmica } \\
\text { Out of operation systems calculated by ASIT }\end{array}$ \\
\hline Sweden & $\begin{array}{l}\text { Jan-Olof Dalenbäck } \\
\text { Svensk Solenergi / CHALMERS }\end{array}$ & $\begin{array}{l}\text { Svensk solenergi; } \\
\text { CHALMERS University of Technology }\end{array}$ \\
\hline
\end{tabular}


Switzerland

SWISSOLAR
SWISSOLAR - Schweizerischer Fachverband

für Sonnenenergie: Markterhebung Sonnenergie, 2012

http://www.swissolar.ch/fileadmin/files/swissolar_neu/

1._Unsere_Themen/1.07_Schweizer_Solarindustrie/

Marktumfrage_2012.pdf

Out of operation systems calculated by SWISSOLAR

\section{Taiwan K.M. Chung}

Energy Research Center -

National Cheng Kung University

Bureau of Energy, Ministry of Economic Affairs,

R.O.C.

Out of operation systems calculated by Bureau of Energy,

Ministry of Economic Affairs, R.O.C.

\begin{tabular}{ll}
\hline Tunisia & Moncef Njaimi \\
ANME - National Agency of Energy Conservation
\end{tabular}

Turkey A. Kutay Ulke

EZINC Metal San. Tic. A.S.

ANME - National Agency of Energy Conservation

EZINC Metal San. Tic. A.S.

Out of operation systems calculated by AEE INTEC

$\begin{array}{ll}\text { United Kingdom } & \begin{array}{l}\text { ESTIF - European Solar Thermal } \\ \text { Industry Federation }\end{array}\end{array}$

SAHWIA - Solar Air Heating World Air collectors: SAHWIA

Industry Association

http://www.estif.org/statistics/st_markets_in_europe_2012/

United States Les Nelson

IAPMO Solar Heating \& Cooling Programs

Water Collectors: IAPMO Solar Heating \& Cooling Programs; provided by Les Nelson (Director); Out of operation systems considered based on historical data (1975 - 2009) from U.S. Department of Energy (DoE) Energy Information Administration (EIA)

John Hollick

Air collectors: SAHWIA

SAHWIA - Solar Air Heating World Industry Association 


\subsubsection{Additional literature and web sources used}

\section{The following reports and statistics were used in this report.}

- Associação Portuguesa da Indústria Solar (APISOLAR): Oservatório Solar: Estatisticas Solar Termico 2012; February 2013

- Bundesamt für Energie (BFE): Markterhebung Sonnenenergie 2012 - Teilstatistik der Schweizerischen Statistik der erneuerbaren Energien; prepared by SWISSOLAR, Thomas Hostettler, Bern, Switzerland July 2013

- Bundesministerium für Verkehr, Innovation und Technologie (BMVIT): Innovative Energietechnologien in Österreich - Marktentwicklung 2012; prepared by Peter Biermayr et al., Vienna, Austria May 2013

- Bundesverband Solarwirtschaft e.V. (BSW-Solar): Statistische Zahlen der deutschen Solarwärmebranche (Solarthermie) 2012; accessed on November 2013

- ClearSky Advisors Inc.: Survey of Active Solar Thermal Collectors, Industry and Markets in Canada (2012); Prepared by ClearSky Advisors Inc., Dr. Reda Djebbar, Natural Resources Canada, July 2013

- EurObserv'ER: Solar Thermal Barometer, May 2013

- European Solar Thermal Industry Federation (ESTIF): Solar Thermal Markets in Europe, Trends and Market Statistics 2012; Belgium - Brussels; June 2013

- Observatoire mediterraneen de l'energie (OME): Solar Thermal in the Mediterranean Region: Market Assessment Report, OME report for GSWH-UNEP-UNDP; September 2012

- REN 21: MENA 2013 - MENA renewables status report; June 2013

- REN 21: Renewables 2013 Global Status Report, June 2013

\section{The following online sources were used in this report:}

- http://www.anes.org/

- http://www.aderee.ma/

- http://www.apisolar.pt/

- http://www.asit-solar.com/

- http://www.dasolabrava.org.br/

- http://www.epia.org/home/

- http://www.estif.org/

- http://www.iea-shc.org/

- http://www.mnre.gov.in/

- http://www.ome.org/

- http://www.olade.org/

- http://www.ren21.net/

- http://sahwia.org/

- http://www.solar-district-heating.eu/

- http://www.solarwirtschaft.de/

- http://www.solrico.com/

- http://www.solarthermalworld.org/ 


\subsection{List of Figures}

Figure 1: Countries represented in this report

Figure 2: Total capacity in operation [GWel], [GW th 2013 and annual energy generated [TWhel], [TWh $\left.\mathrm{Th}_{\mathrm{th}}\right]$

(Sources: AEE INTEC, GWEC, EPIA, IEA PVPS, Navigant Research, Ocean Energy Systems, REN21,

U.S. Geothermal Energy Association)

Figure 3: Share of the total installed capacity in operation (glazed and unglazed water and air collectors)

by economic region at the end of 2012

Figure 4: Distribution of the total installed capacity in operation by collector type in 2012 - WORLD

Figure 5: Distribution of the total installed capacity in operation by collector type in 2012 - EUROPE $\ldots \ldots \ldots \ldots \ldots \ldots \ldots$

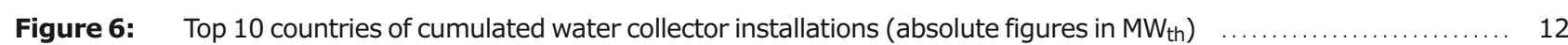

Figure 7: Top 10 countries of cumulated water collector installations (relative figures in $\mathrm{kW}_{\text {th }}$ per 1,000 inhabitants) $\ldots . \quad 12$

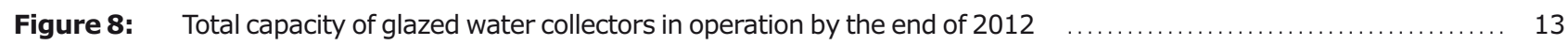

Figure 9: Total capacity of glazed water collectors in operation in $\mathrm{kW}_{\text {th }}$ per 1,000 inhabitants by the end of $2012 \ldots \ldots \ldots$

Figure 10: Total capacity of glazed flat plate and evacuated tube collectors in operation by economic region at the end of 2012

Figure 11: Total capacity of glazed flat plate and evacuated tube collectors in operation by economic region and in $\mathrm{kW}_{\text {th }}$ per 1,000 inhabitants by the end of 2011

Figure 12: Total capacity of unglazed water collectors in operation by the end of 2012

Figure 13: Total capacity of unglazed water collectors in operation in $\mathrm{kW}_{\text {th }}$ per 1,000 inhabitants by the end of $2012 \ldots \ldots$

Figure 14: Share of the newly installed capacity (glazed and unglazed water and air collectors)

by economic regions in 2012

Figure 15: Market growth of newly installed capacity between 2011 and 2012 by economic region

Figure 16: Distribution of the newly installed capacity by collector type in 2012 - WORLD

Figure 17: Distribution of the newly installed capacity by collector type in 2012 - EUROPE

Figure 18: Top 10 markets for glazed and unglazed water collectors in 2012 (absolute figures in $M_{\text {th }}$ )

Figure 19: Top 10 markets for glazed and unglazed water collectors in 2012 (relative figures in $\mathrm{kW}_{\text {th }}$ per 1,000 inhabitants)

Figure 20: Newly installed capacity of glazed water collectors in 2012

Figure 21: Newly installed capacity of glazed water collectors in 2012 in $\mathrm{kW}_{\text {th }}$ per 1,000 inhabitants $\ldots \ldots \ldots \ldots \ldots \ldots \ldots . \ldots 22$

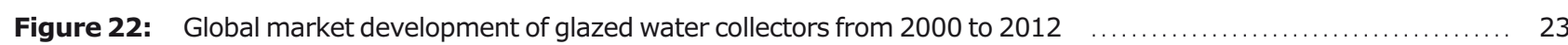

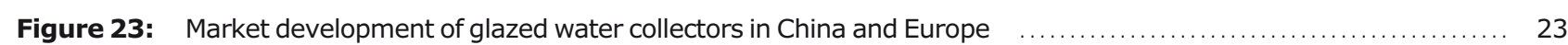

Figure 24: Market development of glazed water collectors in Europe and the Rest of World (excluding China) $\quad \ldots . \ldots \ldots . . .24$

Figure 25: $\quad$ Market development of glazed water collectors in Rest of World (excluding China and Europe) $\quad \ldots \ldots \ldots \ldots \ldots . . \ldots 24$

Figure 26: Annual installed capacity of glazed water collectors in $\mathrm{kW}_{\text {th }}$ per 1,000 inhabitants from 2000 to $2012 \quad \ldots \ldots \ldots 25$

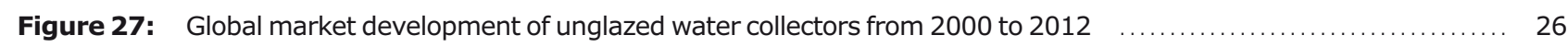

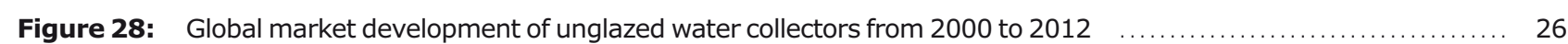

Figure 29: Share of energy savings and $\mathrm{CO}_{2}$ reduction by type of application of glazed and unglazed water collectors in operation by the end of 2012

Figure 30: Annual collector yield of unglazed and glazed water collectors in operation by end of 2012

Figure 31: Annual energy savings in oil equivalent by unglazed and glazed water collectors in operation by end of 2012 . 29

Figure 32: Contribution to $\mathrm{CO}_{2}$ reduction by unglazed and glazed water collectors in operation by end of $2012 \quad \ldots \ldots \ldots . . .30$

Figure 33: Distribution by type of solar thermal collector for the total installed water collector capacity in operation by the end of 2012

Figure 34: Distribution by type of solar thermal collector for the newly installed water collector capacity in 2012

Figure 35: Distribution by type of system for the total installed glazed water collector capacity in operation by the end of 2012

Figure 36: Distribution by type of system for the newly installed glazed water collector capacity in 2012 
Figure 37: Distribution of solar thermal systems by application for the total installed water collector capacity by economic region in operation by the end of 2012

Figure 38: Distribution of solar thermal systems by application for the newly installed water collector capacity by economic region in 2012

Figure 39: Distribution of solar thermal systems by application for the 10 leading markets of the newly installed glazed water collector capacity in 2011

Figure 40: European large-scale solar heating systems by end of 2013

(Source: Jan-Olof Dalenbäck - Chalmers University of Technology)

Figure 41: Market development 2004-2013 of small to large-scale solar air conditioning and cooling systems (Source: Climasol, EURAC, Fraunhofer ISE, Green Chiller, Rococo, Solem Consulting, Tecsol)

Figure 42: Global solar process heat applications in operation

(Source: IEA SHC Task49/IV SHIP database, accessed on 2014-05-16)

Figure 43: Hydraulic scheme of the swimming pool reference system

Figure 44: Hydraulic scheme of the domestic hot water pumped reference system for single family houses $\quad \ldots \ldots \ldots \ldots \ldots . . \ldots 4$

Figure 45: Hydraulic scheme of the domestic hot water thermosiphon reference system for single family houses $\ldots . . . .44$

Figure 46: Hydraulic scheme of the domestic hot water pumped reference system for multifamily houses $\ldots \ldots \ldots \ldots \ldots . . \ldots 5$

Figure 47: Hydraulic scheme of the solar-combi reference system for single and multifamily houses $\ldots \ldots \ldots \ldots \ldots \ldots . . \ldots 6$

\subsection{List of Tables}

Table 1: Total capacity in operation by the end of $2012\left[\mathrm{MW}_{\mathrm{th}}\right]$

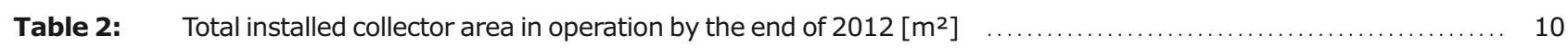

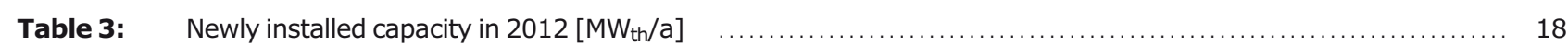

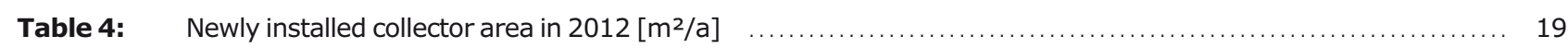

Table 5: Calculated annual collector yield and corresponding oil equivalent and $\mathrm{CO}_{2}$ reduction of glazed

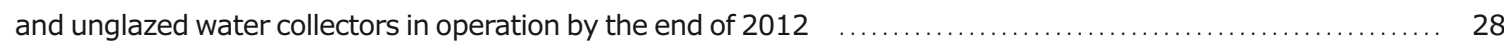

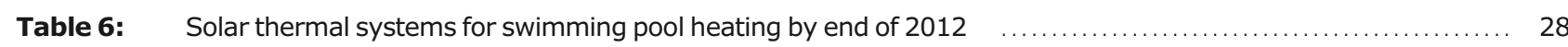

Table 7: $\quad$ Solar thermal systems for domestic hot water heating in single family houses by end of $2012 \quad \ldots \ldots \ldots \ldots \ldots . \ldots 3$

Table 8: $\quad$ Solar thermal systems for domestic hot water heating in multifamily houses by end of $2012 \quad \ldots \ldots \ldots \ldots \ldots \ldots$

Table 9: Solar combi system reference for single and multifamily houses and the total collector area

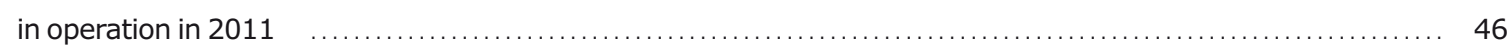

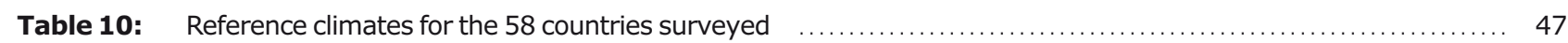

Table 11: Inhabitants by the end of 2012 of the 58 surveyed countries in alphabetical order $\ldots \ldots \ldots \ldots \ldots \ldots \ldots \ldots \ldots$

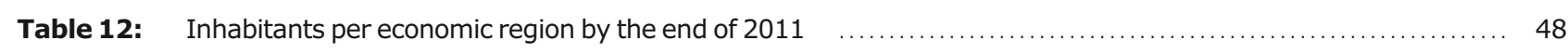

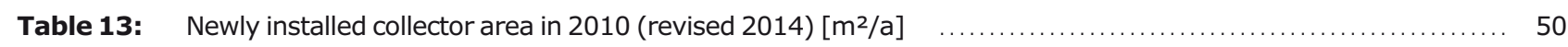

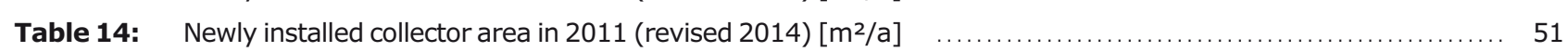

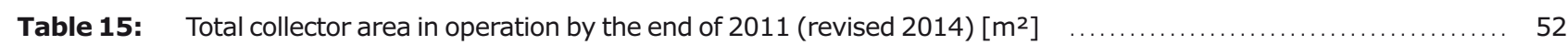

